\title{
User's Guide to a Data Base of Current Environmental Monitoring Projects in the U.S.-Canadian Transboundary Region
}
M. Y. Ballinger
M. D. Bettinson
J. Defferding
C. S. Glantz
E. G. Chapman

November 1987

Prepared for the U.S. Environmental Protection Agency under a Related Services Agreement with the U. S. Department of Energy under Contract DE-AC06-76RLO 1830

Pacific Northwest Laboratory

Operated for the U.S. Department of Energy by Battelle Memorial Institute 
Although the research described in this article has been funded wholly or in part by the United States Environmental Protection Agency (EPA), it has not been subjected to EPA review and therefore does not necessarily reflect the views of EPA and no official endorsement should be inferred.

\title{
DISCLAIMER
}

This report was prepared as an account of work sponsored by an agency of the United States Government. Neither the United States Government nor any agency thereof, nor Battelle Mernorial Institute, nor any of their employees, makes any warranty, expressed or implied, or assumes any legal liability or responsibility for the accuracy, completeness, or usefulness of any information, apparatus, product, or process disclosed, or represents that its use would not infringe privately owned rights. Reference herein to any specific commercial product, process, or service by trade name, trademark, manufacturer, or otherwise, does not necessarily constitute or imply its endorsement, recommendation, or favoring by the United States Government of any agency thereof, or Battelle Memorial Institute. The views and opinions of authors expressed herein do not necessarly state or reflect those of the United States Government or any agency thereof, or Battelle Memorial Institute.

\author{
PACIFIC NORTHWEST LABORATORY \\ operated by \\ BATTELLE MEMORIAL INSTITUTE \\ for the \\ UNITED STATES DEPARTMENT OF ENERGY \\ under Contract DE-AC06-76RLO 1830
}

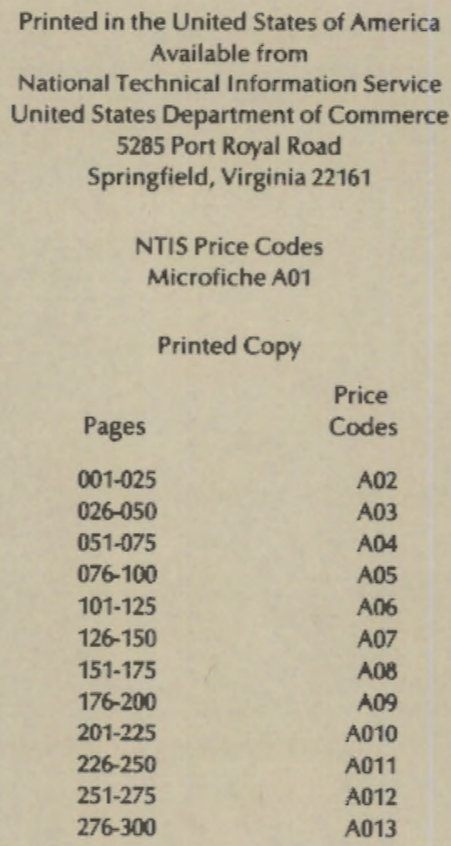


USER'S GUIDE TO A DATA BASE OF CURRENT ENVIRUNMENTAL MONITORING

PRUJECTS IN THE U.S.-CANADIAN

TRANSBOUNDARY REGION
M. Y. Ballinger
J. Defferding
E. G. Chapman
M. D. Bettinson
C. S. Glantz

November 1987

Prepared for

the U.S. Environmental Protection Agency under a Related Services Agreement with the U.S. Department of Energy under Contract DE-AC06-76RLO 1830 Interagency Agreement DW89931447-01-1

Pacific Northwest Laboratory Richland, Washington 99352 
This document describes how to use a data base of current transboundary reyion environmental monitoring projects. The data base was prepared from data provided by Glantz et al. (1986) and Concord Scientific Corporation (1985), and contains information on 226 projects with monitoring stations located within $400 \mathrm{~km}$ (250 mi) of the U.S.-Canadian border. The original data base contained the 184 records shown in the appendices of Glantz et al. (1986). The 42 records shown in Appendix $A$ of this report were added in 1987 and cover the Great Lakes Region. They are based on information from Concord Scientific Corporation (1985). The data base is designed for use with the dBASE III PLUS data management systems on IBM-compatible personal computers.

Data-base searches are best accomplished using an accompanying command file called RETRIEVE or the dBASE command LIST. The RETRIEVE file produces a form in which the user enters the project characteristics of interest and indicates whether or not formatted results are to be directed to a screen or to a printer. The RETRIEVE command file is recommended for searches where project characteristics can be linked by conditional. AND. statements, while the LIST command is recommended for searches involving conditional. OR. statements. In both cases, the user must carefully select the substrings on which the search is to be based. Example search requests and subsequent output are presented to illustrate substring selections and applications of the data base. 
. 


\section{CONTENTS}

SUMMARY

1.0 INTROOUCTION

1.1

2.0 DATA-BASE STORAGE AND STRUCTURE

2.1

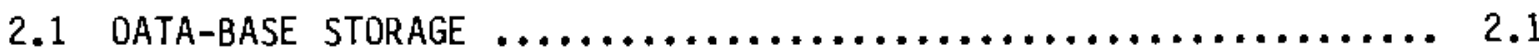

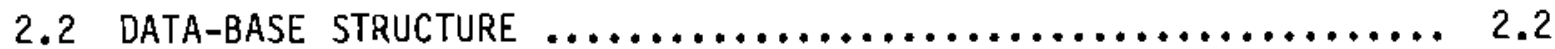

2.3 DISPLAY OF DATA-BASE STRUCTURE $\ldots \ldots \ldots \ldots \ldots \ldots \ldots \ldots \ldots \ldots \ldots \ldots \ldots \ldots$

2.4 RELATING DATA-BASE RECORDS ANO REPORT DESCRIPTIONS $\ldots \ldots \ldots \ldots \ldots .4$

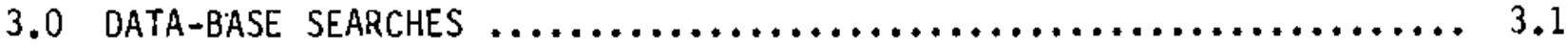

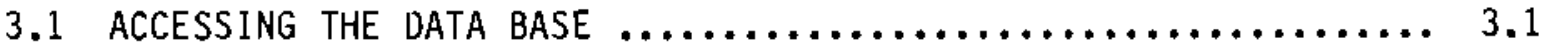

3.1.1 Main Control Menu--Program Options ............... 3.2

3.1.2 Main Option 1-.Adding New Data ................. 3.2

3.1 .3 Main Option 2--Editing Data $\ldots \ldots \ldots \ldots \ldots \ldots \ldots \ldots \ldots . . \ldots \ldots$

3.1 .4 Main Dption $3--$ Deleting Data $\ldots \ldots \ldots \ldots \ldots \ldots \ldots \ldots \ldots \ldots \ldots \ldots \ldots \ldots$

3.1.5 Main 0ption 4--Retrieving Report ................ 3.7

3.1.6 Main Option 6--Removing Records Marked for Deletion .... 3.10

3.1.7 Main 0ptions 7 and 8 --System Controls ............. 3.10

3.2 DATA-BASE SEARCHES USING MAIN OPTION 5--THE LIST COMMAND $\ldots \ldots .3 .13$

3.3 SCREEN OUTPUT FROM LIST CDMMANDS $\ldots \ldots \ldots \ldots \ldots \ldots \ldots \ldots \ldots \ldots \ldots \ldots . . \ldots \ldots$

3.4 SELECTING SUBSTRINGS $\ldots \ldots \ldots \ldots \ldots \ldots \ldots \ldots \ldots \ldots \ldots \ldots \ldots \ldots \ldots \ldots \ldots \ldots \ldots$

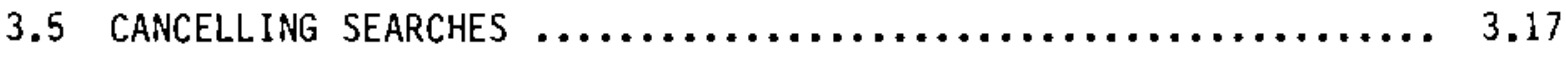

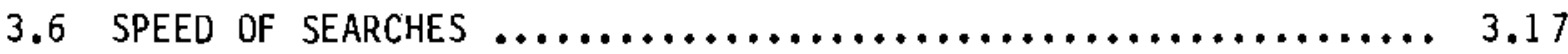

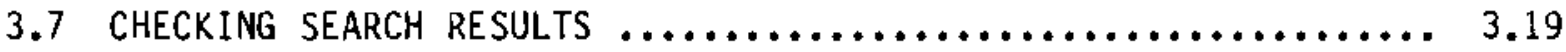

3.8 MENU-ORIVEN SEARCHES USING THE ASSIST COMMAND $\ldots \ldots \ldots \ldots \ldots \ldots \ldots$ 
4.0 USING THE DATA BASE: CAVEATS $\ldots \ldots \ldots \ldots \ldots \ldots \ldots \ldots \ldots \ldots \ldots \ldots \ldots \ldots \ldots \ldots \ldots \ldots, 4$

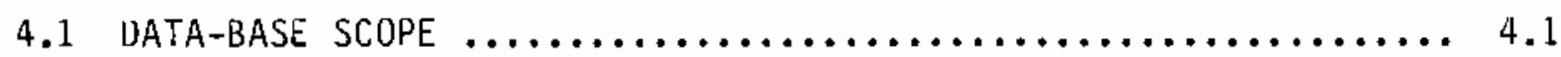

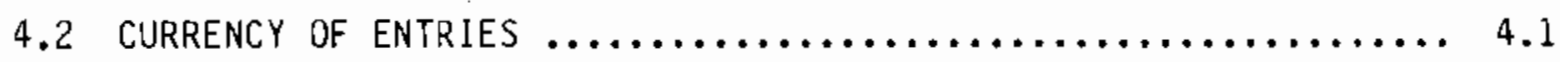

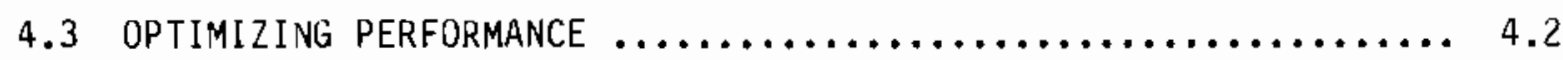

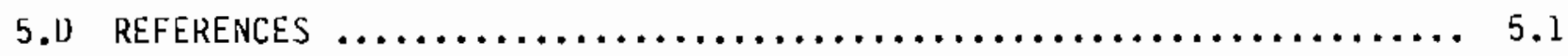

APPENDIX A - LIST OF CLASSIFICATION COOES, SUMMARIES, AND DATA-BASE RECURDS OF PROJECTS DESCRIBEU IN CDNCORO SCIENTIFIC CORPORATION (1985)

A.1 


\section{FIGURES}

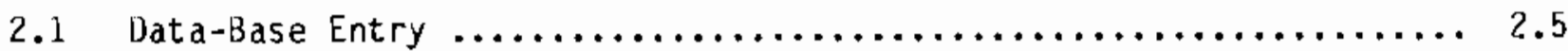

3.1 Main Control Menu $\ldots \ldots \ldots \ldots \ldots \ldots \ldots \ldots \ldots \ldots \ldots \ldots \ldots \ldots, 3.2$

3.2 Initial Template for Adding New Data $\ldots \ldots \ldots \ldots \ldots \ldots \ldots \ldots \ldots . . . \ldots .4$

3.3 Last Template for Adding Data ............................ 3.4

3.4 Selecting a Project Record for Editing $\ldots \ldots \ldots \ldots \ldots \ldots \ldots \ldots \ldots, 3.5$

3.5 First Screen for Editing the Selected Project .................. 3.5

3.6 The Last Edit Screen for the Project in Figure $5 \ldots \ldots \ldots \ldots \ldots \ldots .6 .6$

3.7 Selecting a Project Record for Deleting $\ldots \ldots \ldots \ldots \ldots \ldots \ldots \ldots \ldots . .6 .7$

3.8 Display of a Project Record for Deleting $\ldots \ldots \ldots \ldots \ldots \ldots \ldots \ldots \ldots \ldots . .6$

3.9 An Example Retrieve-MENU Input, Obtained by Using the RETRIEVE

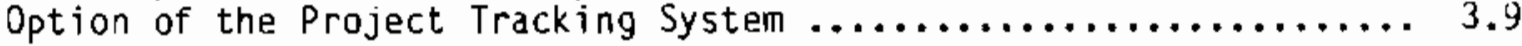

3.10 An Example Screen Output Using the Retrieve Option of the

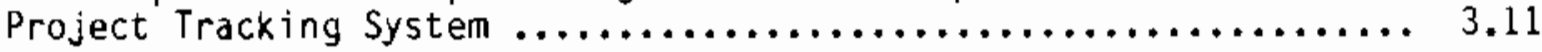

3.11 Hard-Copy Output Produced by the RETRIEvE Option for the Input Given in Figure $3.9 \ldots \ldots \ldots \ldots \ldots \ldots \ldots \ldots \ldots \ldots \ldots \ldots \ldots \ldots \ldots \ldots \ldots \ldots, 12$

3.12 Example Data-Base Search Using the LIST Command-Screen Print to Illustrate the LIST Command Format and Resulting output in a Search for Projects with Monitoring Sites Located in

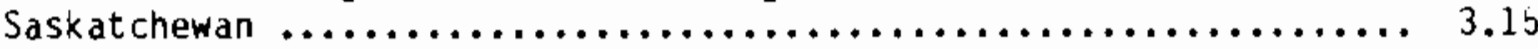

3.13 Example Data-Base Search Using the LIST Command-Screen Print to Illustrate the LIST Command Format and Resulting Dutput in a Search for Saskatchewan Ecosystem Projects Monitoring Organochlorines

3.14 Example Data-Base Search Using the LIST Command-Screen Print to Il lustrate the LIST Command Format and Resulting Output in a Search for Ecosystem Projects Located in Saskatchewan or Ontario that Monitor Either DOT or Cadmium 


\section{TABLES}

2.1 Structure of the BORDER Data-Base File $\ldots \ldots \ldots \ldots \ldots \ldots \ldots \ldots \ldots \ldots \ldots$

3.1 Selected Parameter Character Strings $\ldots \ldots \ldots \ldots \ldots \ldots \ldots \ldots \ldots \ldots \ldots$

A.1 Key to Classification Codes $\ldots \ldots \ldots \ldots \ldots \ldots \ldots \ldots \ldots \ldots \ldots \ldots \ldots \ldots$

A.2 Suminary of the Last 42 Projects in the Border Data Base.......... A.3 


\subsection{INTRODUCTION}

The recently published report entitled An Inventory of Current Environmental Monitoring Projects in the U.S. - Canadian Transboundary Region by Glantz et al. (1986) contained an extensive review of environmental monitoriny activities near the U.S.-Canadian border. A data base of transboundary region environmental monitoring activities for use on a personal computer was prepared from the individual project descriptions contained in Appendices B through $G$ of Glantz et al. In 1987, this data base was supplemented with records describiny the projects in Concord Scientific Corporation (1985). The data base provides ready access to information characterizing the region's environmental monitoring projects and a simple method for identifying projects with selected characteristics.

The data base currently contains descriptions of the 184 environmental monitoring projects that were presented in the appendices of Glantz et al. (1986) and 42 projects presented in Appendix A of this report. All projects involve sampling conducted at sites within $40 \mathrm{D} \mathrm{km}(250 \mathrm{mi})$ of the U.S.-Canadian border. These projects encompass environmental studies in the areas of air and water quality; deposition monitoring; soils, forest, and vegetation research; and ecosystem impacts. Entries emphasize studies related to acid deposition a) though representative projects in other areas of environmental monitoriny are also included. Each project description includes such information as the name of the project; its common acronym; program emphasis; monitoring site locations; time period; parameters measured; protocols employed; frequency of sample collection; data storage information; and the name, address, and phone number of the principal contact for the project.

The data base of transboundary region environmental monitoring projects was created using the dBASE III PLUS data-base management system. The data base was created on, and is designed for use with, IBM-compatible personal computers .

This user's guide is designed to provide an overview of the data base of transboundary region environmental monitoring projects. The data-base structure and the major dBASE III PLUS commands needed for typical searches are 
described. Examples of actual search procedures (input and output) are presented in the following sections. In preparing the guide we have assumed that readers are familiar with the report of Glantz et al. (1986) and with the use of dBASE III PLUS. If the latter is not true, we strongly urge readers to read the tutorial section of their dBASE manual before continuing with this guide or using the monitoring project data base. 


\subsection{UATA-BASE STORAGE ANO STRUCTURE}

The data-base file BORDER holds the project data and is contained on the high-density floppy disk accompanying this manual. A common format was designed for the BORDER data base and the project descriptions in Giantz et al. (1986). The common format represents a compromise between the occasionally conflicting needs of publishing the data in a readable form and achieving optimal data-base performance. By establishing a common format, it was possible to copy formatted text files from the inventory document directly into the BORDER data-base file using a data-processing program. The use of this program ensured correspondence between information presented in the oriyinal inventory document (Glantz et a1. 1986) and in the data base, thus automatically providing a quality-controlled process for generating the data base. The 43 records added in 1987 and shown in Appendix A were appended to the original data base using dBASE III PLUS. The common format also introduced several minor drawbacks, including the need for extra record fields and blank padding in database fields, which can distort screen displays of project data. These drawbacks, and ways to minimize their effect, are discussed in more detail later in this document.

\subsection{DATA-BASE STORAGE}

The BOROER data-base file contains mostly descriptive information and is therefore very large ( 900,000 bytes). One high-density floppy disk or three standard floppy disks are needed to store the entire file; the file can also be transferred to a hard disk. The method of storing the data base is a key factor in determining the lenyth of time needed to perform certain operations; the best performance is obtained with the BORDEK file stored on a hard disk. If the personal computer system employed does not have a hard disk, the highdensity floppy disk can be used directly. In such situations, make sure the disk is inserted in the high-capacity disk drive (usually Drive $A$ on an IBM $P C-A T)$ and the dBASE III PLUS software diskette is loaded into the standardcapacity drive (usually Drive B on an IBM PC-AT). Errors in reading the BORDER file may occur if the high-density disk is not placed in the proper drive. 
The remaining information in this user's guide was written assuming that the user will be employing either a hard disk or a high-density floppy disk to store the BORDER data-base file. Indicated dBASE III PLUS procedures and commands will still work if three standard floppy disks are used for file storage; however, the disks must be manually exchanged whenever the data base is searched. These exchanges greatly increase the length of time required for each search, and this method of storing and using the data base is not recommended.

\subsection{DATA-BASE STRUCTURE}

Each environmental monitoring project entry in Glantz et al. (1986) comprises a single "record" in the BORUER data base. Individual items of project information (i.e., project name, parameters measured, the name of the principa) contact, funding agency) are contained in the project record as "fields." The structure of the BORDER data-base file and a brief description of each field are given in Table 2.1. Note that fields given in this table include several entries that may not appear in individual project descriptions in Glantz et al. (1986). For example, document project descriptions included either the category US or CAN, under which monitoring site locations were listed. In the BORDER data-base file, both US and CAN appear as fields in all records. The "extra" field is a consequence of converting the document project descriptions directly into the BORUER data-base file; the data-processing program performing this conversion requires a consistent set of entry fields, even if no information is included for a particular entry in a given project. Thus, a project with monitoring sites located in the United States will have site location information listed in Glantz et al. under the label US, but the label CAN will not appear in the project description. In the BOROER data-base file, the record corresponding to this particular project will have the same monitoring site information appearing in the field that is labeled US. The CAN field, however, will also be present, but will show blanks. Similarly, blank REFUOCl, REFOOC2, and REFDOC 3 fields will appear in records for which the corresponding Glantz et al. description does not contain reference document listings. 
TABLE 2.1. Structure of the BOROER Data-Base File

\begin{tabular}{|c|c|c|c|c|}
\hline Field & Labels & Type & Width & Description \\
\hline 1 & NAME & Character & 150 & Project Name \\
\hline 2 & TYPE & Character & 75 & Type of project \\
\hline 3 & PARAM & Character & 225 & Parameters monitored \\
\hline 4 & US & Character & 225 & U.S. states where sampling is conducted \\
\hline 5 & OFTEN & Character & 225 & Frequency of sampling \\
\hline 6 & DATES & Character & 150 & Beginning and ending dates of project \\
\hline 7 & HOW & Character & 225 & $\begin{array}{l}\text { How samples are collected and/or where } \\
\text { analyzed }\end{array}$ \\
\hline 8 & QAUC & Character & 150 & $\begin{array}{l}\text { Type of quality assurance/quality } \\
\text { control programs }\end{array}$ \\
\hline 9 & STOR & Character & 225 & How are data stored \\
\hline 10 & CONTACT & Character & 75 & Nane of principal contact \\
\hline 11 & ADORESS & Character & 225 & Address of principal contact \\
\hline 12 & ADDRESS1 & Character & 225 & Continuation of address (if needed) \\
\hline 13 & TELEPH & Character & 75 & Telephone of principal contact \\
\hline 14 & FUNDS & Character & 225 & Funding agency \\
\hline 15 & MISC & Character & 225 & Miscellaneous information \\
\hline 16 & REFDOCl & Character & 225 & First reference document \\
\hline 17 & REFOOC2 & Character & 225 & Second reference document \\
\hline 18 & REFOOC 3 & Character & 225 & Third reference document \\
\hline 19 & CODE & Character & 40 & $\begin{array}{l}\text { Project coding [see Section } 3.2 \text { of } \\
\text { Glantz et al. (1986)] }\end{array}$ \\
\hline 20 & ABREV & Character & 225 & Acronym or abbreviation for project name \\
\hline 21 & CAN & Character & 225 & $\begin{array}{l}\text { Canadian provinces where sampling is } \\
\text { conducted }\end{array}$ \\
\hline
\end{tabular}

Number of data records: 184 


\subsection{UISPLAY OF DATA-BASE STRUCTURE}

Data-base field labels given in Table 1 are needed in specifying certain search cominands, as discussed in Section 3.3. A listiny of the data-base structure, similar to that shown in Tabie 2.1, can be displayed on the video screen by using the dBASE III PLUS command

\section{.LIST STRUCTURE 〈Enter>}

\subsection{RELATING DATA-BASE RECOROS AND REPURT UESCRIPTIONS}

The page and appendix number of a project description in Glantz et al. (1986) corresponding to a particular data-base record can be located via the last entry in the CODE field for the original 184 records. Thus, an entry of $4 C$ at the end of the COUE field shown in Figure 2.1 means that the description of the Hydrologic Bench-mark Network will be found on the fourth page of Appendix C (Page C.4) in Glantz et al. 


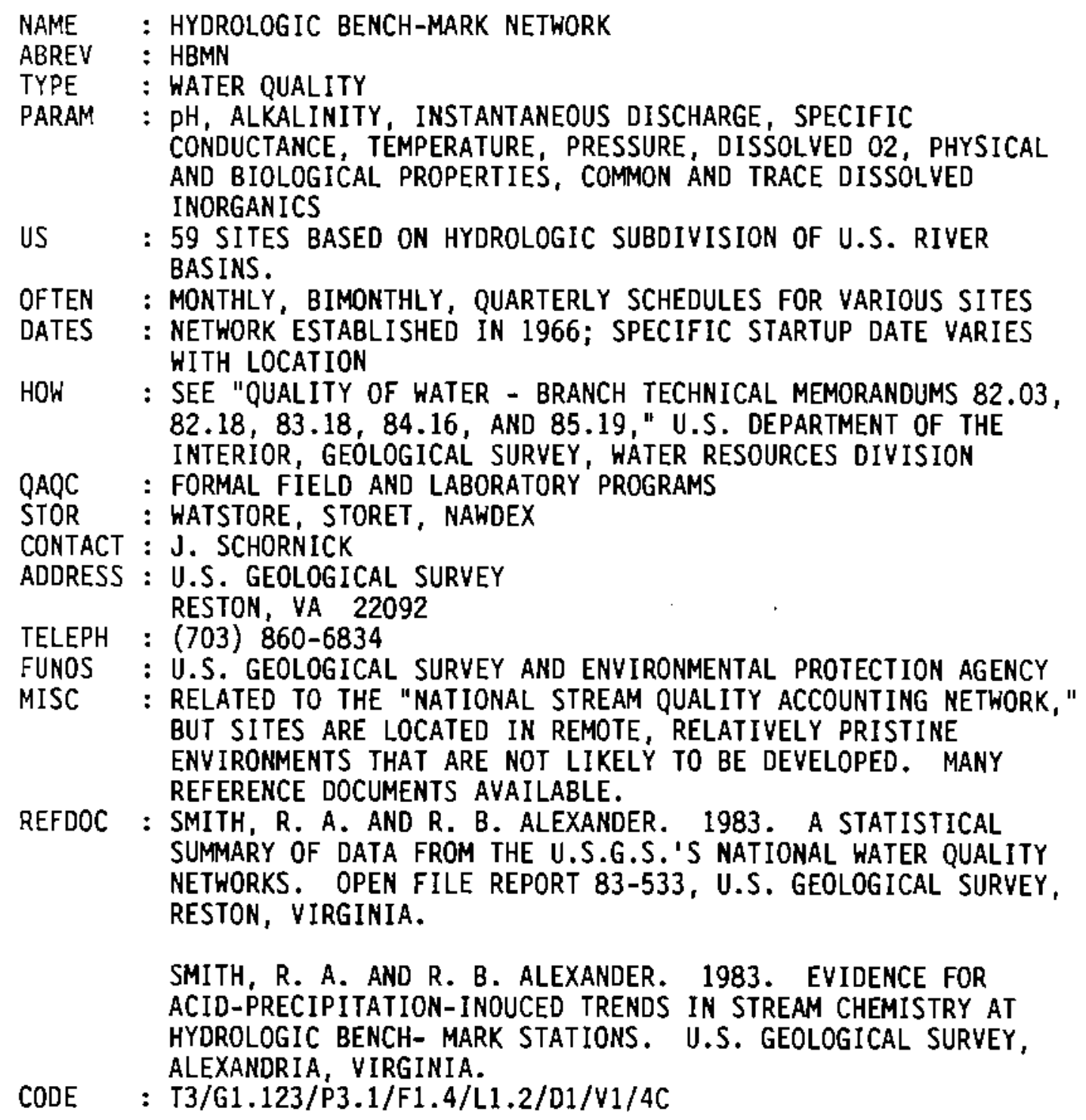

REFDOC : SMITH, R. A. AND R. B. ALEXANDER. 1983. A STATISTICAL SUMMARY OF DATA FROM THE U.S.G.S.'S NATIONAL WATER QUALITY NETWORKS. OPEN FILE REPORT 83-533, U.S. GEOLOGICAL SURVEY, RESTON, VIRGINIA.

SMITH, R. A. AND R. B. ALEXANDER, 1983. EVIDENCE FOR ACID-PRECIPITATION-INOUCED TRENDS IN STREAM CHEMISTRY AT HYDROLOGIC BENCH- MARK STATIONS. U.S. GEOLOGICAL SURVEY, ALEXANDRIA, VIRGINIA.

CODE : T3/G1.123/P3.1/F1.4/L1.2/D1/V1/4C

FIGURE 2.1. Data-Base Entry 


\section{.}




\subsection{DATA-BASE SEARCHES}

In designing the data base of transboundary region environmental monitoring projects, it was anticipated that users would want to extract listings of projects with certain characteristics (such as a summary of all projects in the province of Ontario that involve measurements of mercury) from the data base. Experimentation with dBASE III PLUS and the BORDER data file led us to develop the command file MENU for data-base access, including appending, editing, deleting, and retrieving information (the MENU program is also known as the Project Tracking System). The following sections illustrate how the MENU program can be used to access information from projects with common characteristics. For detailed instructions on how to use other dBASE III PLUS options not included in MENU, readers are urged to consult the dBASE III PLUS reference manuats.

\subsection{ACCESSING THE DATA BASE}

To access the BORDER data-base file, the user must first load the database management system (dBASE III PLUS) into the computer. (See your dBASE III PLUS reference manual if unfamiliar with this step; look under "Running dBASE II I PLUS.")

The following programs must also be loaded to use the MENU program and its options:

- MENU.PRG

- BORD_add.PRG

- BORD_DEL.PRG

- BORD_EDI.PRG

- display.prg

- Listall.prg

- Retrieve.Prg

- rTM.PRG

If the user has a hard disk on which all these programs and BORDER.DBF are located, the command 


\section{>dBASE MENU <Enter>}

will invoke the MENU program. The MENU screen as shown in Figure 3.1 will be displayed. An alternate method of invoking MENU is to use the two commands:

$$
\begin{gathered}
\text { >dBASE 〈Enter> } \\
\text {.DO MENU <Enter> }
\end{gathered}
$$

An alternate method of using the MENU program and its options is to insert the disk with the MENU and supporting programs and BORDER data-base file into a high-density disk drive (usually drive $A$ on an IBM PC-AT). Invoke dBASE with

$$
>\text { dBASE 〈Enter> }
$$

then set default to the high density disk drive with

$$
\text { .SET DEFAULT TO A: 〈Enter> }
$$

followed by

$$
.00 \text { MENU <Enter> }
$$

to invoke MENU.

The MENU program can also be used with a standard floppy disk. However, this method is not recommended since the disks must be continually switched.

\subsubsection{Main Control Menu--Program 0ptions}

The Project Tracking System has several options available, as shown in Figure 3.1. Options 7 and 8 are system controls; the other options control various data input, manipulation, or reporting procedures. 
Current Environmental Monitoring Projects in the U.S.-Canadian Transboundary Region

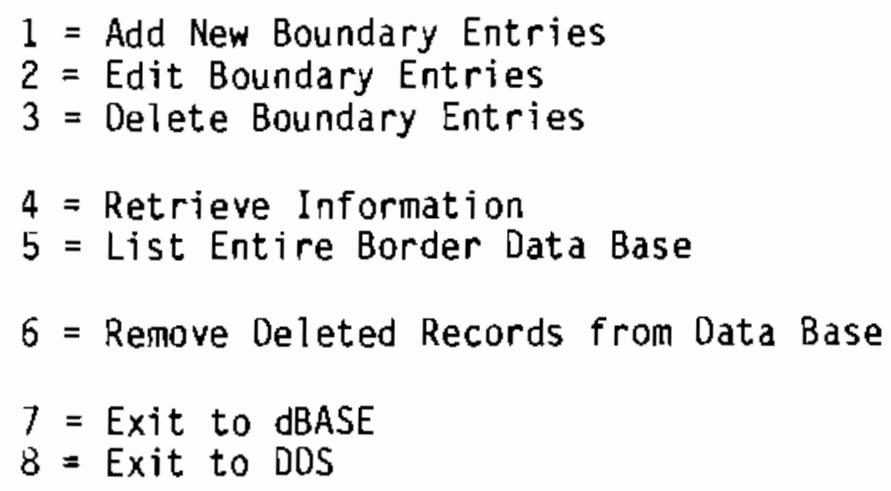

What is your choice?

FIGURE 3.1. Main Control Menu

\subsubsection{Main Option 1--Adding New Data}

The main control menu should be displayed on the screen (see figure 3.1).

The "Add New Boundary Entries" option allows the user to add data on new projects and store this information in the BOROER data-base file. Select this option by entering 〈l> and <Enter〉. Figure 3.2 will appear as shown below. This display allows the user to enter information about a particular project. Because the data-base fields are large, it takes five screens to input information for one project. The user may scroll through the input screens by using the $\langle P g D n\rangle$ key. The arrow keys on the numeric keypad can be used to move the cursor up, down, left, or right to correct errors at any time prior to hitting the 〈Enter> key after the last entry.

After information for this project has been keyed in, the user must follow the instructions at the bottom of the last (fifth) screen. See Figure 3.3. Use the keys:

- $\langle\operatorname{Ctrl}\rangle\langle$ End $>$ - to save information and return to the main menu as shown in Figure 3.1

- 〈EsC〉 - to return to the main menu as shown in Figure 3.1 without saving the current record 
Current Environmental Monitoring Projects in the U.S.-Canadian

Transboundary Region--ADD SCREEN

NAME :

ABREV:

TYPE :

PARAM:

Press $\langle P g D n\rangle$ for additional screens

FIGURE 3.2. Initial Template for Adding New Data

Current Environmental Monitoring Projects in the U.S.-Canadian

Transboundary Region--ADD SCREEN

REFDOC3:

CODE:

$\langle C t r l\rangle\langle E n d\rangle$ to save/quit or $\langle E s c\rangle$ to quit or 〈any other key to continue

FIGURE 3.3. Last Template for Adding Data

- 〈any other key> - to add data for next data-base record.

\subsubsection{Main Option 2--Editing Data}

The main control menu should be displayed on the screen (see Figure 3.1).

The "Edit Boundary Entries" option allows the user to edit a project whose 
record already exists in the data base. Select this option by entering <2>. Figure 3.4 will appear as shown below. This display allows the user to select a project by entering its record number. Note that by hitting the 〈Enter $\rangle$ key before entering a record number the program will skip back to the main menu (Figure 3.1) without editing any data.

Once the user has entered a valid record number (in this exampie, 2l) followed by the 〈Enter> key, the display shown in Figure 3.5 will appear. Once again, because the data-base fields are large, it takes five screens to display information concerning one project record. The user may scroll through the display screens by using the $\langle\mathrm{PgDn}\rangle$ key.

To edit a project's information, the user hits the arrow keys on the numeric keypad to move the cursor up, down, left, or right throughout the displayed data and at the proper locations to make the editing changes. The 〈Ins> key can set the editor to insert text and the 〈Del> key will delete the character at the cursor.

Current Environmental Monitoring Projects in the U.S.-Canadian Transboundary Region--EDIT SCREEN

Enter Record Number:

Press 〈Enter> to quit

FIGURE 3.4. Selecting a Project Record for Editing 
Current Environmental Monitoring Projects in the U.S.-Canadian

Transboundary Region--EUIT SCREEN

NAME: EVALUATION OF THE NATURE OF ACIOIFICATION OF LAKES IN

SOUTHERN QUEBEC AND INCIOENCES ON A SAMPLING NETWORK

ABREV:

TYPE: WATER QUALITY

PARAM: $\quad$ PH, ALKALINITY, MAJOR IONS

Press 〈PgDn> for additional screens

FIGURE 3.5. First Screen for Editing the Selected Project

When the information for this project has been edited, the user must follow the instructions at the bottom of the last (fifth) screen. See Figure 3.6. Use the keys:

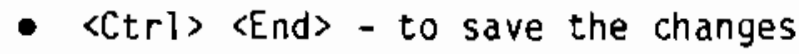

- $\langle E s c\rangle$ - to ignore the changes.

The display shown in Figure 3.4 will reappear on the screen so that the user may continue to edit additional projects if desired. When completed, the user simply hits the <Enter> key instead of a record number. This will return the screen to the main menu shown in Figure 3.1 .

\subsubsection{Main Option 3--Deleting Data}

The main control menu should be displayed on the screen (see Figure 3.1 ).

The "Delete Boundary Entries" option allows the user to delete a project whose data record already exists in the data base. Select this option by entering 〈3〉. Figure 3.7 will appear as shown below. This display allows the user to select a project by entering its record number. Note that by hitting 〈Enter> before entering a record number, the program will skip back to the main menu (Figure 3.1) without deleting any data. 
Current Environmental Monitoring Projects in the U.S.-Canadian Transboundary Region--EDIT SCREEN

REFD0C3:

CODE: T3/G2.1/P0/F3.1/L2.1/D0/V0/15C

$\langle C$ tr $\mid\rangle\langle$ End $\rangle$ to save/exit - $\langle$ Esc $\rangle$ to no save/exit

FIGURE 3.6. The Last Edit Screen for the Project in Figure 5

Current Environmental Monitoring Projects in the U.S.-Canadian Transboundary Region--DELETE SCREEN

Enter Record Number:

Press 〈Enter> to quit

FIGURE 3.7. Selecting a Project Record for Deleting

The selected project will be displayed on the screen (see figure 3.8). The user is asked to verify if this record is to be deleted by answering the question on the bottom of the screen. If it is deleted, the display shown in Figure 3.7 will reappear on the screen so that the user may continue to delete 
Current Environmental Monitoring Projects in the U.S.-Canadian

Transboundary Region--UELETE SCREEN

NAME: EVALUATION OF THE NATURE OF ACIOIFICATION OF LAKES IN

SOUTHERN QUEBEC AND INCIDENCES ON A SAMPLING NETWORK

ABREV:

TYPE: WATER QUALITY

PARAM: $\quad$ PH, ALKALINITY, MAJOR IONS

Delete this record?

FIGURE 3.8. Display of a Project Record for Deleting

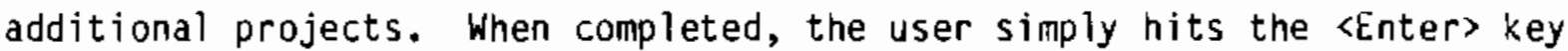
instead of a record number. This will return the screen to the main menu shown in Figure 3.1.

\subsubsection{Main Option 4--Retrieving Report}

The main control menu should be displayed on the screen (see figure 3.1).

The "Retrieve Information" option initiates a simple data-base search. This option provides a form in which the user enters the specific information required in a given field for a project to be selected as output in a data-base search. The user may specify substrings up to 30 characters long for each of the 21 fields in a record. Currently, only one substring per field can be made for each search. The progran interprets substrings in multiple fields as if they were linked by conditional.AND. statements. For example, Figure 3.9 illustrates the input required to search the data base for ongoing deposition monitoring projects that are located in the providence of Ontario and measure sulfate and are funded by the Ontario Ministry of the Environment. Data-base searches involving.OR. statements (e.g., monitoring in Ontario or Quebec), or 


\section{Enter information you want to retrieve: \\ Press $\langle$ Ctrl $\rangle\langle$ End $\rangle$ to continue}

$\begin{array}{ll}\text { NAME } & \\ \text { ABREV } & \\ \text { TYPE } & \text { DEP } \\ \text { PARAM } & \text { SO4 } \\ \text { US } & \\ \text { CAN } & \text { ONTARIO } \\ \text { OFTEN } & \\ \text { DATES } & \text { ONGOING } \\ \text { HOW } & \\ \text { QAOC } & \\ \text { STOR } & \\ \text { CONTACT } & \\ \text { ADDRESS } & \\ \text { ADDRESS1 } & \\ \text { TELEPH } & \\ \text { FUNDS } & \text { ONTARIO MIN } \\ \text { MISC } & \\ \text { REFDOC1 } & \\ \text { REFDOC2 } & \\ \text { REFDOC3 } & \\ \text { CODE } & \end{array}$

FIGURE 3.9. An Example Retrive-MENU Input, Obtained by Using the RETRIEVE Option of the Project Tracking Systern

for multiple substrings in one field (e.g., measurement of sulfate and trace metals), must be initiated using the LIST command (see Section 3.2), rather than the retrieve option.

Select this option by entering <4>. Figure 3.9 will appear as shown below. The user enters selected phrases in the fields of interest and exits the form by moving the cursor out of the shaded entry block (either by using the cursor control or repeatedly striking 〈Enter>).

The program will display the NAME, TYPE, PARAM, US, CAN, CONTACT, and CODE fields of the first entry satisfying the specified conditions. The message

Press $\langle Q\rangle$ to quit $\star \star\langle P\rangle$ to print $\star \star$ 〈any other key to continue search 
then appears. If the user decides to continue, the same fields for the next record satisfying the search conditions are displayed and the message is repeated. if the user quits the search, the program returns a blank retrieve form for inputting the next set of search conditions. Figure 3.10 illustrates the screen output obtained for the retrieve program input given in Figure 3.9 during a full data-base search.

If the printer output is selected, a note is made to print the entry and the next entry satisfying the search conditions is displayed. When the user exits the data-base search all selected entries are printed. Output format is very similar to that used in the Glantz et al. (1986) project descriptions and in Appendix $A$ of this report. Figure 3.11 illustrates the printer output obtained from this menu option.

The retrieve option can be exited by entering a null (blank) form or by hitting the $\langle E S C\rangle$ key while the form is displayed.

\subsubsection{Main Option 6--Removing Records Marked for Deletion}

The main control menu should be displayed on the screen (see figure 3.1)

The "Remove Deleted Records from Data Base" option removes all records marked for deletion from the BOROER data-base file. This option can be selected at any time. It should be done whenever a large number of projects have been deleted, because leaving records marked for deletion in the data base increases the response time of the Project Tracking System.

Select this option by entering $\langle 6\rangle$. The following message will appear on the screen:

Please wait, deleted records are being removed

\subsubsection{Main Options 7 and 8--System Controls (exiting the proyram)}

The main control menu should be displayed on the screen (see figure 3.1 ).

The "Exit to dBASE" and "Exit to DOS" options are selected when the user wants to quit the MENU program. The user can exit to dBASE by hitting a $<7>$ to 
NAME : ACIO PRECIPITATION IN ONTARIO STUDY, LIMNOLOGY UNIT NETWORK

TYPE : BULK DEPOSITION

PARAM : pH, CONDUCTIVITY, ALKALINITY, SO4, NO3, NH4, CI, TOTAL P, $\mathrm{Na}, \mathrm{K}, \mathrm{Ca}, \mathrm{Mg}, \mathrm{Al}, \mathrm{Fe}, \mathrm{Mn}, \mathrm{Pb}, \mathrm{Si}, \mathrm{Zn}, \mathrm{DISSOLVED} \mathrm{ORGANIC}$ CARBON, DISSOLLVED INORGANIC CARBON

CAN : I9 SITES AROUND LAKES IN ONTARIO; CURRENTLY 4 SITES ARE IN OPERATION APPROXIMATELY $225 \mathrm{KM}$ NORTH OF TORONTO

CONTACT : P. J. DILLON

CODE : T4/G2.2/P1.2/F2.2/L1.2/D1/VI/37D

Press $Q$ to quit ** $P$ to printer ** anything else to continue

NAME : ACID PRECIPITATION IN ONTARIO STUDY (CUMULATIVE NETHORX)

TYPE : WET DEPOSITION

PARAM : $\mathrm{pH}$, CONDUCTIVITY, ACIDITY, SO4, N03, NH4, TOTAL KJELDAHL

Nitrogen, $\mathrm{P}, \mathrm{Na}, \mathrm{K}, \mathrm{Ca}, \mathrm{Mg}, \mathrm{A}], \mathrm{Cd}, \mathrm{Cu}, \mathrm{Fe}, \mathrm{Mn}, \mathrm{Ni}, \mathrm{Rb}, \mathrm{Zn}$ CAN : 36 SITES IN ONTARIO

CONTACT : MARIS LUSIS

CODE : T4/G2.2/P1.2/F2.3/L1.2/D1/V1/38D

Press Q to quit * P to printer ** anything else to continue

NAME : ACID PRECIPITATION IN ONTARIO STUDY (EVENT NETHORK)

TYPE : WET DEPOSITIOH

PARAM : $\mathrm{pH}$, CONDUCTIVITY, ACIDITY, SO4, $\mathrm{NO3}, \mathrm{KH} 4, \mathrm{Cl}, \mathrm{Na}, \mathrm{K}, \mathrm{Ca}, \mathrm{Mg}$

CAN : 16 SITES IN ONTARIO; 4 EACH IN KINGSTON, LONDON, DORSET ANO ATIKOKAN AREAS

CONTACT : MARIS LUSIS

CODE : T4/G2.2/PO/F2.2/L1.2/01/V1/390

Press $Q$ to quit $\star P$ to printer * anything else to continue

FIGURE 3.10. An Example Screen Output Using the Retrieve Option of the Project Tracking System 


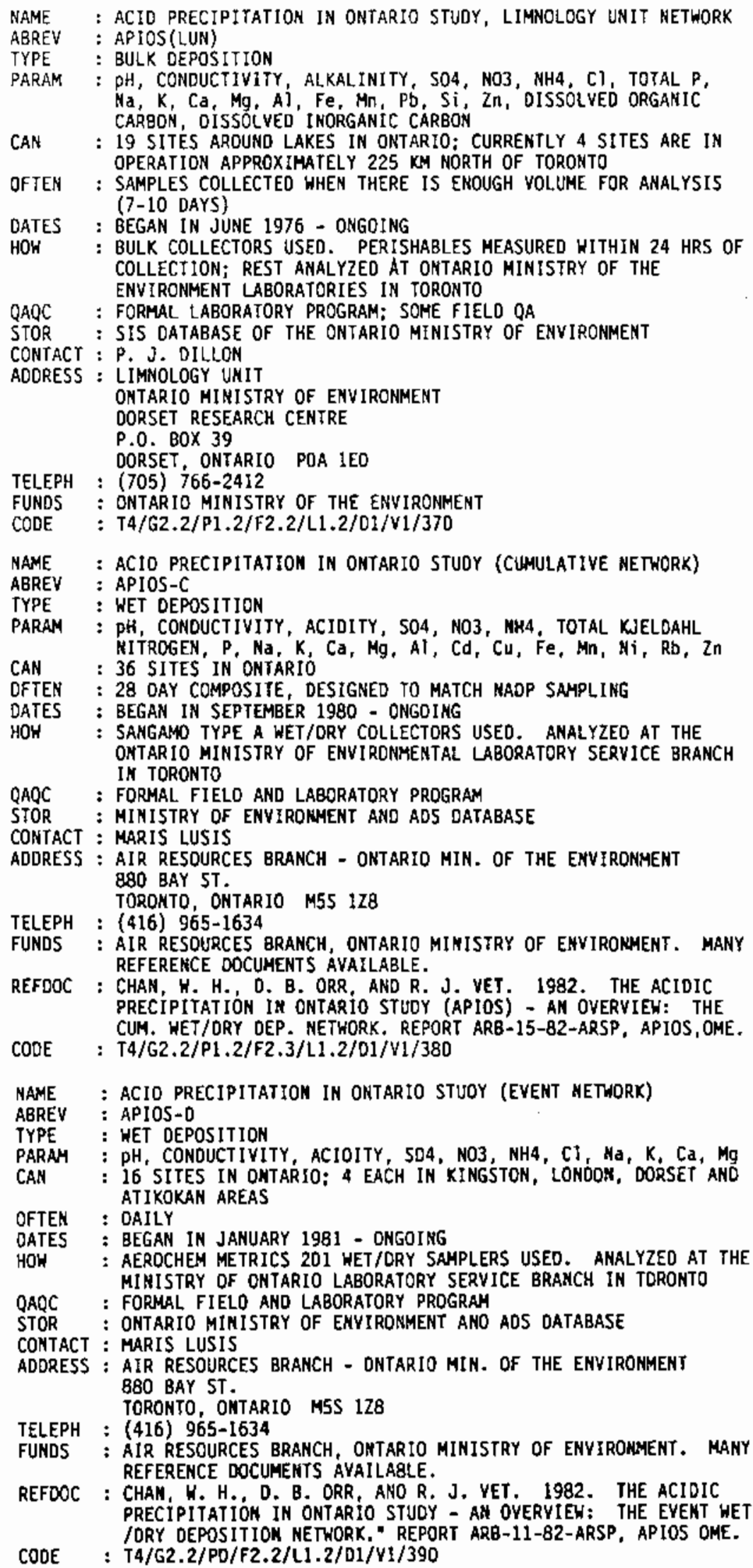

FIGURE 3.11. Hard-Copy Output Produced by the RETRIEVE Option for the Input Given in Figure 3.9 
select option 7. This will stop the Project Tracking System, close all open files, reset all defaults, and return the screen to the dot prompt in dBASE. The user can exit to DoS by hitting a $\langle 8\rangle$ to select option 8 . This will stop the program, exit dBASE, and return the screen to DOS.

\subsection{DATA-BASE SEARCHES USING MAIN OPTION 5--THE LIST COMMAND}

The LIST command with the substring symbol $\$$ is recomnended for complex data-base searches where conditional .OR. statements are required, such as situations where one field must be scanned for more than one specified substring. The LIST comnand, for example, would be used in a search for projects with sampling sites in New York or Vermont or Maine that monitor mercury or arsenic. The LIST command can also be used in place of the RETRIEVE option in the Program Tracking System. A series of sample LIST commands and resulting screen outputs are presented in Figures 3.12 to 3.14 . The commands illustrate how to search the data base for

- projects with monitoring sites in Saskatchewan (Figure 3.12)

- ecosystem projects with sites in Saskatchewan that monitor organochlorines (Figure 3.13 )

- ecosystem projects with sites in Saskatchewan or Ontario that monitor either DDT or cadmium (Figure 3.14)

with the commands entered respectively as

- -list name, param, code for 'SASK' \$ can

- .list name, code for 'Sask' \$ can . and. 'ecos' \$ type .and. 'DRGANOCHLOR' \$ PARAM

- .list name, code for ('Sask' \$ can .or. 'Ontar' \$ can ) .And. 'ecos' $\$$ TYPE .AND. ('DOT' \$ PARAM .OR. 'Cd' \$ PARAM)

Note that the first and second data-base searches could have been conducted using the RETRIEVE option.

Detailed information on the LIST command and use of conditional.AND. and .OR. statements can be found in the dBASE III PLUS reference manuals (AshtonTate 1984, 1986). 
- LIST NAME, PARAM, CODE FOR 'SASK' \$ CAN

Record\# NAME

PARAM

CODE

9 POPLAR RIVER THERMAL POWER PLANT AMBIENT AIR MONITORING PROGRAM

SUSPENDED PARTICULATES, S02, METEOROLOGICAL DATA

T2/G2.3/P2.12/

\section{F4.2/L1.2/D2/V1/9B}

39 MONITORING ACTIVITIES AT POPLAR RIVER AND BOUNDARY DAM POWERSTATIONS pH, S04, N03, OTHER MAJOR IONS, ALKALINITY, METALS,

CONDUCTIVITY

T3/G2.3/P3.1/F

\section{2/L1.2/D2/V1/35C}

49 CANADIAN AIR AND PRECIPITATION MONITORING NETWORK

PRECIPITATION: $\mathrm{pH}$, CONDUCTIVITY, ACIDITY, SO4, N03, NH4, Cl, $\mathrm{K}, \mathrm{Ca}, \mathrm{Mg}, \mathrm{Na}$ AIR: S04, $\mathrm{N03}, \mathrm{Cl}, \mathrm{Na}, \mathrm{NH} 4, \mathrm{HN} 03, \mathrm{SO2}$

T4/G2.12/P2.1/

F1.3/L2.2/D1/V1/10D

\section{GEOCHEMICAL DATA: CANADIAN SURVEY}

WATER ( $\mathrm{pH}, \mathrm{V}, \mathrm{F}$ ) SOME SURVEY AREAS ALSO HAVE SEDIMENTS $\mathrm{Zn}, \mathrm{Cu}, \mathrm{Pb}, \mathrm{Ni}, \mathrm{Co}, \mathrm{Ag}$, $\mathrm{Mn}, \mathrm{Cd}, \mathrm{Fe}, \mathrm{Mo}, \mathrm{V}, \mathrm{AS}, \mathrm{Hg}, \mathrm{V}$, AND IONS ON IGNITION AT 500 DEGREES CELSIUS ( $\mathrm{F}, S$ $b, W, B a$, Sn AND Au)

$1.2 / F 4.3 / L 1.2 / D 2 / V 1 / 2 G$

T7.36/G2.123/P

116 MONITORING ORGANOCHLORINES IN PEREGRINE FALCONS AND THEIR PREY

ORGANOCHLORINES INCLUDING CHLOROBENZENES, HEPTACHLOR

DT, ENDRIN, CHLORDANE, TRANS-NONACHLOR, MIREX, PCBS

\section{$.1 / \mathrm{F} 1.2 / \mathrm{L} 1.2 / \mathrm{D} 2 / \mathrm{V} 1 / 3 \mathrm{G}$}

120 ACCUMULATION AND EFFECTS OF CONTAMINANTS IN AQUATIC BIOTA

CHLOROPHENOLS, BENZOTHIAZOLES, LINDANE, ORGANOCHLORINES, AS, $\mathrm{Hg}, \mathrm{Pb}$

\section{$1.1 / \mathrm{F} 1.1 / \mathrm{L} 2.1 / \mathrm{D} 2 / \mathrm{V} 1 / 7 \mathrm{G}$}

FIGURE 3.12. Example Data-Base Search Using the LIST Command-Screen Print to Illustrate the LIST Command Format and Resulting Output in a Search for Projects with Monitoring Sites Located in Saskatchewan. Output includes the content of the NAME, PARAM, and CODE fields, and illustrates the difficulties in reading a multiple-field output. Compare with screen output format produced by RETRIEVE program (Figure 3.10). 
- LIST NAME, CODE FOR 'SASK' \$ CAN .AND. 'ECOS' \$ TYPE .AND. 'ORgANOCH' \$ PARAM Record\# NAME

CODE

116 MONITORING ORGANOCHLORINES IN PEREgRINE FALCONS AND THEIR PREY

T7.8/G2.123/P1.1/F1.2/L1.2/D2/V1/3G

120 ACCUMULATION AND EFFECTS OF CONTAMINANTS IN AQUATIC BIOTA

T7.368/G2.12/P1.1/F1.1/L2.1/D2/V1/7G

FIGURE 3.13. Example Data-Base Search Using the LIST Command-Screen Print to Illustrate the LIST Command Format and Resulting Output in a Search for Saskatchewan Ecosystem Projects Monitoring Organochlorines. Only the name and code fields are displayed, making the output easier to read.

- LIST Name, CODE FOR ('SASK' \$ CAN .OR. 'ONTAR' \$ CAN) .AND. 'ECOS' \$ TYPe .ÁÑū - ('DDT' \$ PARAM .OR. 'Cd'\$ PARAM) Record\# NAME

COOE

115 GEOCHEMICAL DATA: CANADIAN SURVEY

T7.36/G2.123/P1.2/F4.3/L1.2/D2/V1/2G

116 MONITORING ORGANOCHLORINES 1N PEREGRINE FALCONS AND THE1R PREY

T7.8/G2.123/P1.1/F1.2/L1.2/D2/V1/3G

173 CASE STUDY OF SELECTED TOXIC SUBSTANCES IN ESSEX REGION

T7.2468/G2.2/P1.1/F1.3/L1.1/D2/V0/61G

FIGURE 3.14. Example Data-Base Search Using the LIST Command-Screen Print to Illustrate the LIST Command Format and Resulting Output in a Search for Ecosystem Projects Located in Saskatchewan or Ontario that Monitor Either DDT or Cadmium. Oniy the name and code fields are displayed, making the output easier to read.

\subsection{SCREEN OUTPUT FROM LIST COMMANDS}

As shown in Figures 3.12 to 3.14 , the output from the LIST commands includes the number of the projects satisfying the specified search conditions, plus a printing of the fields specified by the user. The output for some 
fields, such as the PARAM field in Figure 3.12, is not printed on the screen in a convenient format. This is a drawback of using a similar format for both the document and data base, and is caused by the field lengths in BORDER being multiples of 60 characters. Extensive restructuring and editing of the data base would be required to fully eliminate this condition.

To minimize this problem, we recommend that for most LIST command applications the user request that only the record number, NAME field, and CODE field be displayed on the screen. The user can subsequently review other project fields to extract needed information by either using the Project Tracking System (see Section 3.1) or finding the page in Glantz et al. (1986) or Appendix A that corresponds to a given record (see Section 2.4). The problem can be circumvented if specjfications can be reformatted to allow use of the RETRIEVE option.

\subsection{SELECTING SUBSTRINGS}

Proper substring specifications are vital for proper and efficient use of the data set with both the RETRIEVE option or the LIST command. For most applications, users will want to scan for key substrings rather than for the entire content of a field. For example, to determine which projects monitor in Saskatchewan, the CAN field must be searched for the substring SASKATCHEWAN or a combination of letters within this province name that are not found in another province name (i.e., SASK or SAS).

The RETRIEVE option automatically scans for substrings. However, users employing the LIST command must make sure that they include the substring symbol \$ rather than any dBASE equivalency symbol, such as $=$, or formats for complete strings. Otherwise, searching the CAN field for the complete string SASKATCHEWAN (i.e., entering the command for Figure 3.12 as .LIST NAME, CONTACT, CODE FOR CAN = 'SASKATCHEWAN') will only identify projects in which Saskatchewan is the first province listed in the field.

Substrings for use in both the RETRIEVE option and the LIST command must be carefully selected and entered to ensure that dBASE selects the programs with the proper characteristics during its search. For example, entering ' SASK' for the CAN field (where a space precedes the first letter) as part of 
either a RETRIEVE entry or a LIST command would cause the search to miss any projects where the first word in the CAN field was Saskatchewan, because no blank precedes the letter $S$ in these records. Similarly, specifying 'CON' as a search substring in the US field would not only identify projects with sites in Connecticut, but also those with stations in Wisconsin. The user must also be carefur to specify the correct letter case in a substring; entering the string 'PH' in the PARAM field is not equivalent to entering ' $\mathrm{pH}$ '. The former substring identifies projects with words such as PHYSICAL in the parameter field, while the latter substring identifies projects where $\mathrm{pH}$ measurements are made. Because all entries in all fields (except PARAM) are in capital letters, it is helpful to engage 〈Caps Lock> while in dBASE.

To minimize confusion in searches involving the US and CAN fields, all state or provincial names are spelled out in the data base; no abbreviations have been used in these fields. Selected key parameters in the PARAM field (as determined through discussions with U.S. Environmental Protection Agency personnel) were reviewed for consistency, and phrases used in the data base for these key parameters are summarized in Table 3.1. Note that a search for projects monitoring ozone should be entered as 'OZONE' rather than '03', as the latter phrase would yield projects measuring nitrate ion ('N03'). Users should also carefully note which analytes use a mixed-case abbreviation (e.g., 'pH', ' $\mathrm{Hg}$ ').

\subsection{CANCELLING SEARCHES}

A RETRIEVE option search that is sent to a printer or any LIST command search can be stopped by hitting $\langle E s c\rangle$. The MENU screen (Figure 3.1) will then appear.

\subsection{SPEED OF SEARCHES}

The speed with which the data-base searches are executed is a strong function of the manner in which the data are stored. With the data base stored on a Tallgrass Technologies TG-5025 hard disk and operating from an IBM PC, the typical LIST commands illustrated in Figures 3.12 to 3.14 required 20 to 60 seconds to complete. It took several minutes to complete the simple LIST 
TABLE 3.1. Selected Parameter (PARAM Field) Character Strings. When performing data-base searches involving these analytes, enter the character string exactly as shown; do not interchange upper and lower case letters.

Analyte

\begin{tabular}{lll} 
Ammonium ion & & NH4 \\
Asbestos (a) & ASBESTOS \\
Benzo( $\alpha$ ) pyrene & BENZO[A]PYRENE \\
Dichlorodiphenyltrichloroethane & DDT \\
Lead & Pb \\
Mercury & Hg \\
Mirex & MIREX \\
Nitrate ion & NO3 \\
Nitric acid & HNO3 \\
Nitrous 0xides & NOX \\
Ozone & OZONE \\
pH & PH \\
Polycyclic aromatic hydrocarbons & PAHs \\
Polychlorinated biphenyls & PCBS \\
Sulfate ion & SO4 \\
Sulfur dioxide & SO2 \\
Toxaphene & TOXAPHENE \\
& \\
\hline (a) Does not currently appear as a parameter \\
monitored in any data-base record; indi- \\
cated string is recommended for future \\
use.
\end{tabular}

\begin{tabular}{|c|c|}
\hline & \\
\hline Ammonium ion & $\mathrm{NH} 4$ \\
\hline Asbestos $(a)$ & ASBESTOS \\
\hline Benzo $(\alpha)$ pyrene & BENZO[A]PYRENE \\
\hline Dichlorodiphenyltrichloroethane & DDT \\
\hline Lead & $\mathrm{Pb}$ \\
\hline Mercury & $\mathrm{Hg}$ \\
\hline Mirex & MIREX \\
\hline Nitrate ion & N03 \\
\hline Nitric acid & HN03 \\
\hline Nitrous Oxides & Nox \\
\hline Ozone & OZONE \\
\hline $\mathrm{pH}$ & $\mathrm{pH}$ \\
\hline Polycyclic aromatic hydrocarbons & PAHs \\
\hline Polychlorinated biphenyls & PCBS \\
\hline Sulfate ion & SO4 \\
\hline Sulfur dioxide & 502 \\
\hline Toxaphene & TOXAPHENE \\
\hline
\end{tabular}

Character String

NH4

ASBESTOS

PRENE

operation illustrated in Figure 3.12 with the data base stored on a single, high-density floppy disk on an IBM PC-AT. The use of multiple, regular-density floppy disks would have taken even longer and involved the manual swapping back and forth of data disks. These searches took place on the original 184-record data base and would take a little longer with the addition of 43 records. 


\subsection{CHECKING SEARCH RESULTS}

We strongly recommend that users check the contents of the fields used in formulating the LIST command after dBASE III has identified projects having the characteristics specified in a search request. This step will ensure that identified projects actually have the desired characteristics, rather than simply contain a specified substring in an unexpected place. This check is especially important for new users of the data base, as unexpected appearances of selected substrings may appear. Experience with the system aids the judicious selection of substrings.

\subsection{MENU-DRIVEN SEARCHES USING THE ASSIST COMMAND}

dBASE III PLUS contains a menu-driven routine for formatting commands obtained through the tutorial ASSIST command. We do not recommend using this feature for formatting LIST command data-base searches, as the menu is not tajlored for substring comparison requests. The entire field must be entered for the project to be identified. If a substring is used, the project will not be identified. 



\subsection{USING THE DATA BASE: CAVEATS}

Users of any data base must be aware of the scope, purpose, and limitations under which the data base was compiled. The following sections briefly discuss characteristics of a data base and will, we hope, aid users in interpreting the information obtained from $i t$. Users are urged to consult Glantz et al. (1986) for a more complete discussion of these topics.

\subsection{DATA-BASE SCOPE}

The data-base file BORDER contains information on projects that were described in Glantz et a1. (1986); it is not a data base of all environmental monitoring projects in the transboundary region. In compiling the original inventory, emphasis was placed on obtaining information on large-scale programs involving large geographic regions, long time periods of monitoring, or extensive measurement programs. Project coverage is thus geared toward large-scale, federally funded programs. In addition, the Glantz et at. (1986) document was designed to be used with the Concord Scientific Corporation (CSC) report entitled A Review of Atmospheric Deposition Networks in the Great Lakes Basin (1985). In 1987, the projects described in the CSC report that were not already in Glantz et al. were added to the data base. A more complete discussion of inventory coverage of the original data base can be found in Section 3.3 of Glantz et al. (1986).

\subsection{CURRENCY OF ENTRIES}

Information on the original 184 projects included in the data base was current as of March 1986. The 43 added projects shown in Appendix A are current as of September 1987 for the entries that were verified. Those that were not verified contain information current as of 1985, when the CSC report was published. Verification is identified in the CODE field of the entries as shown by Table A.1. $V 1$ in the code field denotes verification by the primary contact. vo denotes no verification. Our experience in compiling the inventory indicates that most projects are continualiy evolving. Some projects listed as "ongoing" will be terminated in the next few years while new projects 
begin periodically. Some existing projects may significantly change in scope, including monitoring site locations or parameters measured. Some data-base entries, such as the name, address, and phone numbers of principal contacts, change frequently as people move to new positions and offices are moved or reorganized. Thus, to maintain the usefulness of this data base, entries must be periodically updated and new projects added. Changes to the data base can be made using the MENU program once the new information is compiled.

Biennial reconfirmation of the material in the BORDER data base is strongly advised. Users opting to edit the data base themselves are urged to keep at least one copy of the original BOROER data-base file.

\subsection{OPTIMIZING PERFORMANCE}

The structure of the current data base was based on anticipated user needs and influenced by the time and funding available for producing the necessary files. Users desiring to optimize performance may want to modify and edit the structure of the BORDER data base file so that extended features of the dBASE III PLUS management system can be used. We advise undertaking this procedure only after substantial experimentation with the current form of the data base and more complete definitions of the desired applications have been established. 


\subsection{REFERENCES}

Ashton-Tate. 1984. dBASE III User Manual. Culver City, California.

Ashton-Tate. 1986. dBASE III PLUS Users Manual. Culver City, California.

Concord Scientific Corporation (CSC). 1985. A Review of Atmospheric Deposition Networks in the Great Lakes Basin. CSC. J587, Downsview, Ontario.

Glantz, C. S., M. Y. Ballinger and E. G. Chapman. 1986. An Inventory of Current Environimental Monitoring Projects in the U.S. - Canadian Transboundary Region. PNL-5880, Pacific Northwest Laboratory, Richland, Washington. 


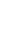




\section{APPENDIX A}

LIST OF CLASSIFICATION CODES, SUMMARIES, AND DATA BASE RECORDS OF PROJECTS DESCR IBED IN CONCORD SCIENTIF IC CORPORATION (1985) 
TABLE A.1. Key to Classification Codes

\begin{tabular}{|c|c|c|c|}
\hline Project Features & $\begin{array}{c}\text { Parameter } \\
\text { Abbreviation }\end{array}$ & Possible Value & Code \\
\hline Project Type & $T^{(a)}$ & $\begin{array}{l}\text { Air } \\
\text { Water } \\
\text { Deposition } \\
\text { Forest/Vegetation } \\
\text { Soils } \\
\text { Ecosystem }\end{array}$ & $\begin{array}{l}2 \\
3 \\
4 \\
5 \\
6 \\
7\end{array}$ \\
\hline Geographic Area & $G(b)$ & $\begin{array}{l}\text { U.S. } \\
\text { Canada } \\
\text { Eastern } \\
\text { Central } \\
\text { Western }\end{array}$ & $\begin{array}{l}1 \\
2 \\
0.1 \\
0.2 \\
0.3\end{array}$ \\
\hline \multicolumn{4}{|l|}{ Parameters } \\
\hline Monitored & $\mathrm{P}$ & $\begin{array}{l}\text { Non-Criteria Pollutant } \\
\text { Water Quality Criteria Pollutants } \\
\text { Primary Project Objective } \\
\text { Secondary Project Objective } \\
\text { Air Quality Criteria Pollutants } \\
\text { Gases } \\
\text { Particulates } \\
\text { Possible Criteria Pollutants } \\
\text { (Analytes not Specified) } \\
\text { Water } \\
\text { Air }\end{array}$ & $\begin{array}{l}0 \\
1 \\
0.1 \\
0.2 \\
2 \\
0.1 \\
0.2 \\
3 \\
0.1 \\
0.2\end{array}$ \\
\hline \multicolumn{4}{|l|}{ Funded Source } \\
\hline and Level & $F$ & $\begin{array}{l}\text { Not Available } \\
\text { Federal } \\
\text { State/Provincial } \\
\text { Private } \\
\text { Combined } \\
\text { Not Available } \\
\text { Small } \\
\text { Medium } \\
\text { Large } \\
\text { Very Large }\end{array}$ & $\begin{array}{l}0 \\
1 \\
2 \\
3 \\
4 \\
0.0 \\
0.1 \\
0.2 \\
0.3 \\
0.4\end{array}$ \\
\hline \multicolumn{4}{|l|}{ Duration of } \\
\hline Monitoring & L & $\begin{array}{l}\text { Currently Operating } \\
\text { Stopped } \\
\text { Total monitoring period }<5 \mathrm{yr} \\
\text { Total monitoring period }>5 \mathrm{yr}\end{array}$ & $\begin{array}{l}1 \\
2 \\
0.1 \\
0.2\end{array}$ \\
\hline
\end{tabular}


TABLE A.1. (contd)

\begin{tabular}{|c|c|c|c|}
\hline Project Features & $\begin{array}{c}\text { Parameter } \\
\text { Abbreviation }\end{array}$ & Possible Value & Code \\
\hline $\begin{array}{l}\text { Data Located in } \\
\text { Centralized Data Base }\end{array}$ & D & $\begin{array}{l}\text { No Information } \\
\text { Yes } \\
\text { No }\end{array}$ & $\begin{array}{l}0 \\
1 \\
2\end{array}$ \\
\hline $\begin{array}{l}\text { Entry Verified by } \\
\text { Project Personne } 1\end{array}$ & $v$ & $\begin{array}{l}\text { Yes } \\
\text { No }\end{array}$ & $\begin{array}{l}1 \\
0\end{array}$ \\
\hline $\begin{array}{l}\text { Data obtained from } \\
\text { Concord Scientific } \\
\text { Corporation (1985) (b) }\end{array}$ & $\csc$ & Not Applicable & Not Applicable \\
\hline
\end{tabular}

(a) Codes 2-6 available for subclassifying Ecosystem projects, along with "Biological - .8". See Glantz, C. S., M. Y. Ballinger, and E. G. Chapman. 1986. An Inventory of Current Envi ronmental Monitoring Projects in the U.S.-Canadian Transboundary Region. PNL-5880. Pacific Northwest Laboratory, Richland, Washington.

(b) Concord Scientific Corporation (CSC). 1985. A Review of Atmospheric Deposition Networks in the Great Lakes Basin. CSC.J587. Downsview, Ontario. 
TABLE A.2. Summary of the Last 42 Projects in the Border Data Base

Entry

No.

185

186

187

188

189

190

191

192

193

194

195

196

197

198

199

200

201

202

203

204

205

206

207

208

209

210

211
Project Title

Metals Monitoring

Quantity and Quality of Urban Storm Runoff

in the Irondequoit Creek Basin Near

Rochester, New York

PCBs in Precipitation in the Lake Michigan Basin

Inputs of PCBs from the Atmosphere to Lakes Huron and Michigan

Solubility of Metal Ions in Rain Water

Source Apportionment of Rain Water Impurities in Central Illinois

Field Intercomparison of Sulfate and Dry Deposition Monitoring and Measurement

Effects of Chicago Emissions on Local Precipitation Chemistry: A Preliminary Report

Chemical Differences Between Event and Weekly Precipitation Samples in Northeastern Illinois

Organic Compounds in Air and Precipitation Nanticoke Environmental Management Program Evidence for the Long Distance Atmospheric Acid Snowpack Chemistry in Pennsylvania Organochlorines in Precipitation in the Great Lakes Region

Organic Substance in the Rainfall of Lake

Pennsylvanie State University Precipitation Collectors intercomparison Study

Deposition of Nutrients and Major Ions By Precipitation in South Central Ontario Great Lakes Atmospheric Deposition Network

Wisconsin Acid Deposition Monitoring Research Program

A Precipitation Sampler Intercomparison

Dorset Intercomparison Study of the APIOS, $A P N$, and Ontario Hydro Event Sampling Methodologies

Sudbury Environmental Studies

Atmospheric Transport of Toxaphene to Lake Michigan

U.S. EPA Region V Monitoring Network

National Dry Deposition Network

Trace Metals and Strong Acid Composition of Rain and Snow in Northern Minnesota

Minnesota Pollution Control Agency Acid
Principal

Contact

$\underline{\text { Page }}$

Len Barrie

A. 5

Bi]l Kappel

A. 6

Tom Murphy

A.7

Tom Murphy

A.8

Donald Gatz

A.9

Donald Gatz

A. 10

Donald Gatz

A. 11

Douglas Sisterson

A. 12

Douglas Sisterson

A. 13

Neville Reid

A. 14

Maris Lusis

A. 15

R. S. Wingender

A. 16

Davis Dewalle

A. 17

William Strachan

A. 18

William Strachan

A. 19

Dsnnis Lamb

A. 20

Peter Dillon

A. 21

Edward Klappenbach

A. 22

Julian Chazin

A. 23

Walter Chan

A. 24

Walter Chan

A. 25

Walter Chan

A. 26

Cliff Rice

A. 27

Chuck Elly

A. 28

Barry Martin

A.29

David Thornton

A. 30

Cliff Twarosk $i$

A.31 
TABLE A.2. (contd)

\begin{tabular}{|c|c|c|c|}
\hline $\begin{array}{l}\text { Entry } \\
\text { No. }\end{array}$ & Project Title & $\begin{array}{l}\text { Principal } \\
\text { Contact } \\
\end{array}$ & Page \\
\hline 212 & $\begin{array}{l}\text { Atmospheric Deposition of Selected Chemicals } \\
\text { and Their Effect on Nonpoint Source } \\
\text { Pollution in the Twin Cities Metropolitan } \\
\text { Area, Minnesota }\end{array}$ & Robin Brown & A.32 \\
\hline $\begin{array}{l}213 \\
214\end{array}$ & $\begin{array}{l}\text { U.S. Inhalable Particulate Network } \\
\text { Survey of PCBs in Ambient Air Across the } \\
\text { Prvince of Ontario }\end{array}$ & $\begin{array}{l}\text { Dave Hinton } \\
\text { Eugene Singer }\end{array}$ & $\begin{array}{l}\text { A. } 33 \\
\text { A. } 34\end{array}$ \\
\hline 215 & $\begin{array}{l}\text { Relationship Between Pb and Pb210 in Aerosol } \\
\text { and Precipitation at a Semiremote Site in } \\
\text { Northern Wisconsin }\end{array}$ & & \\
\hline 216 & $\begin{array}{l}\text { Concentration of Airborne PCBs Over Lake } \\
\text { Michigan }\end{array}$ & Anders Andren & A. 36 \\
\hline 217 & $\begin{array}{l}\text { Atmospheric Deposition of Particulate } \\
\text { Organic Carbon and Polyaromatic } \\
\text { Hydrocarbons to Lake Michigan }\end{array}$ & Anders Andren & A. 37 \\
\hline $\begin{array}{l}218 \\
219\end{array}$ & $\begin{array}{l}\text { New York State Air Monitoring Network } \\
\text { USGS New York State Precipitation } \\
\text { Monitoring Network }\end{array}$ & $\begin{array}{l}\text { Donald Gower } \\
\text { Chuck Barnes }\end{array}$ & $\begin{array}{l}\text { A. } 38 \\
\text { A.39 }\end{array}$ \\
\hline 220 & Atmospheric Input of Trace Metals to Lake & Steven Eisenreich & A. 40 \\
\hline 221 & $\begin{array}{l}\text { Michigan } \\
\text { An Experimental Study of Lake Loacing by } \\
\text { Aerosol Transport and Dry Deposition in } \\
\text { The Lake Erie Basin }\end{array}$ & Herman Sievering & A. 41 \\
\hline 222 & $\begin{array}{l}\text { Pollution From Land Use Activities } \\
\text { Reference Group }\end{array}$ & Marie Sanderson & A. 42 \\
\hline 223 & $\begin{array}{l}\text { Chemical Elements in Atmospheric Aerosol } \\
\text { Dver Southern Lake Michigan: The } \\
\text { Contribution of the Lake Source }\end{array}$ & Herman Sievering & A. 43 \\
\hline 224 & $\begin{array}{l}\text { Transport and Dry Deposition of Trace } \\
\text { Metals Over Southern Lake Michigan }\end{array}$ & Herman Sievering & A. 44 \\
\hline 225 & $\begin{array}{l}\text { Atmospheric Concentrations and Deposition } \\
\text { of PCBs to Lake Superior }\end{array}$ & Steven Eisenreich & A. 45 \\
\hline 226 & $\begin{array}{l}\text { Atmospheric Deposition of Heavy Metals in } \\
\text { Central Ontario }\end{array}$ & Dean Jeffries & A. 46 \\
\hline
\end{tabular}




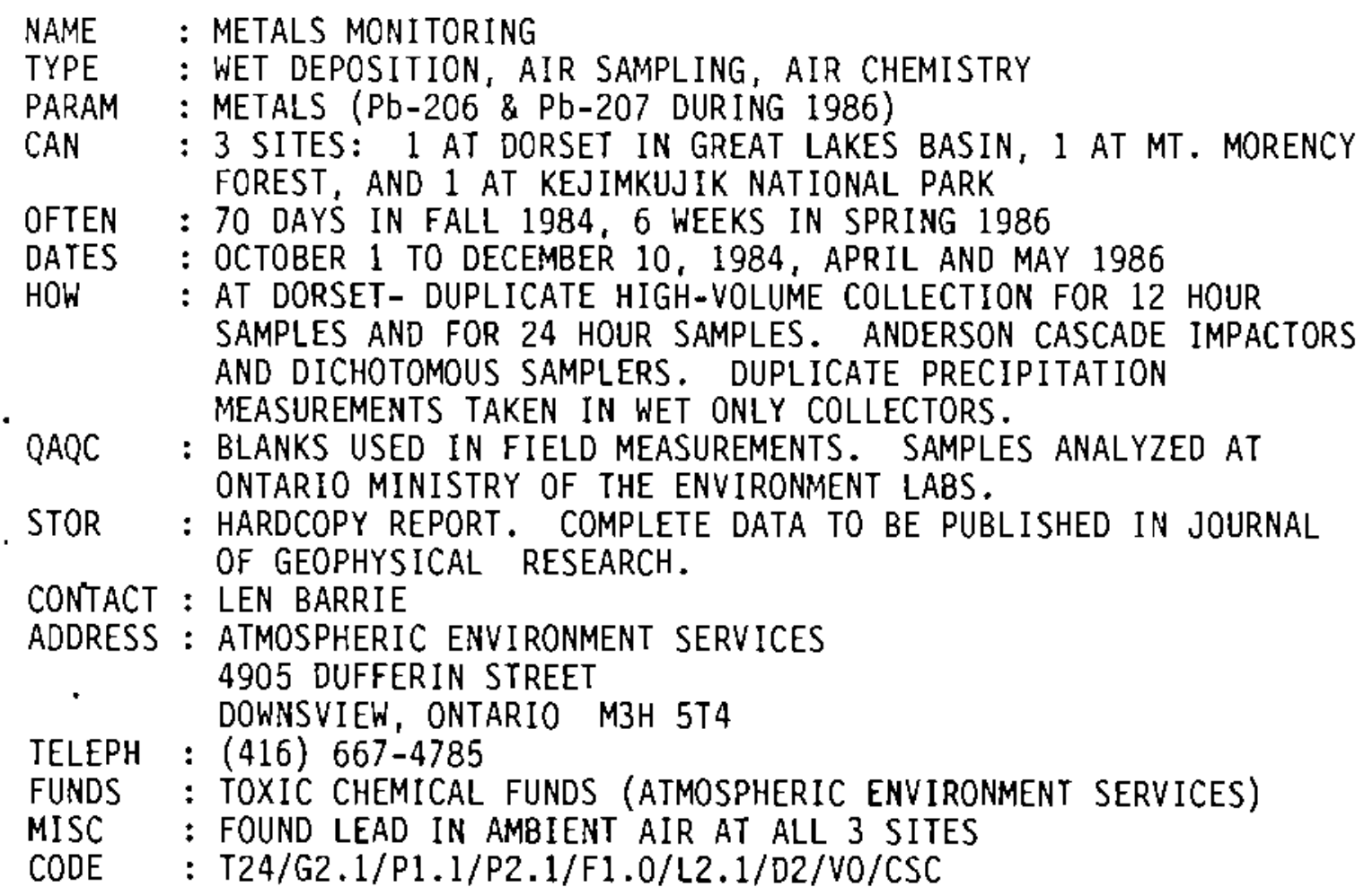




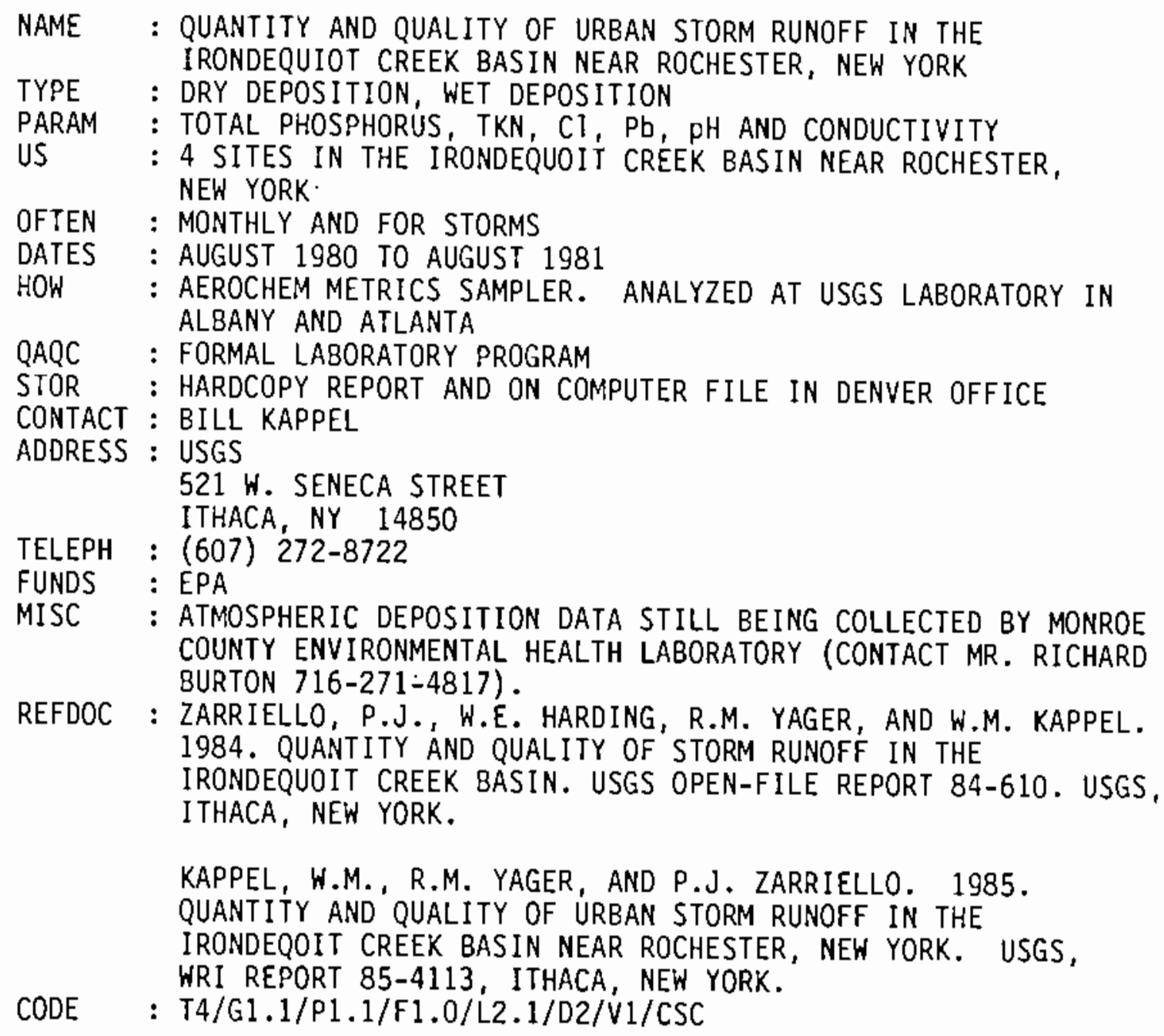




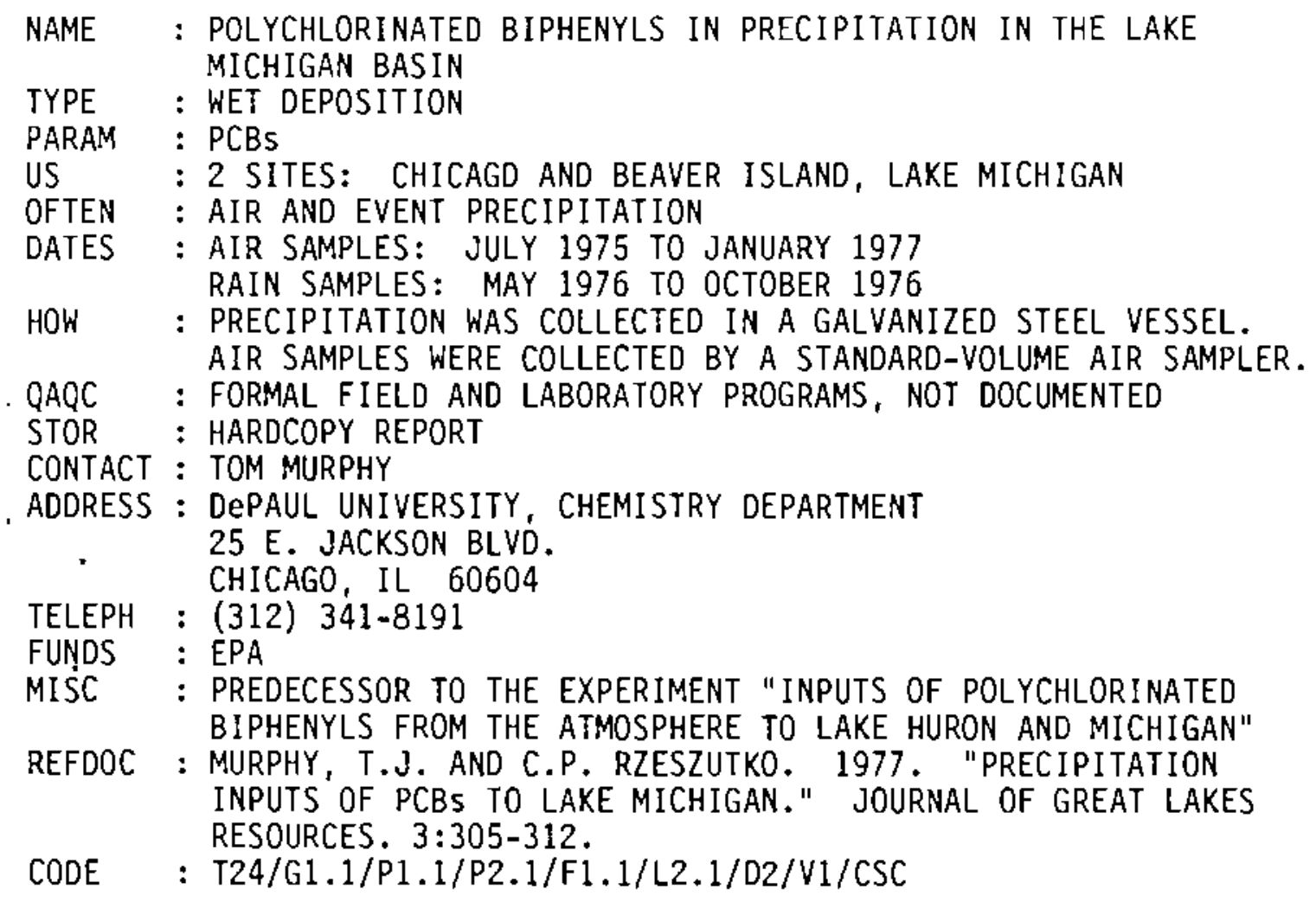

CODE : T24/G1.1/P1.1/P2.1/F1.1/L2.1/D2/V1/CSC 


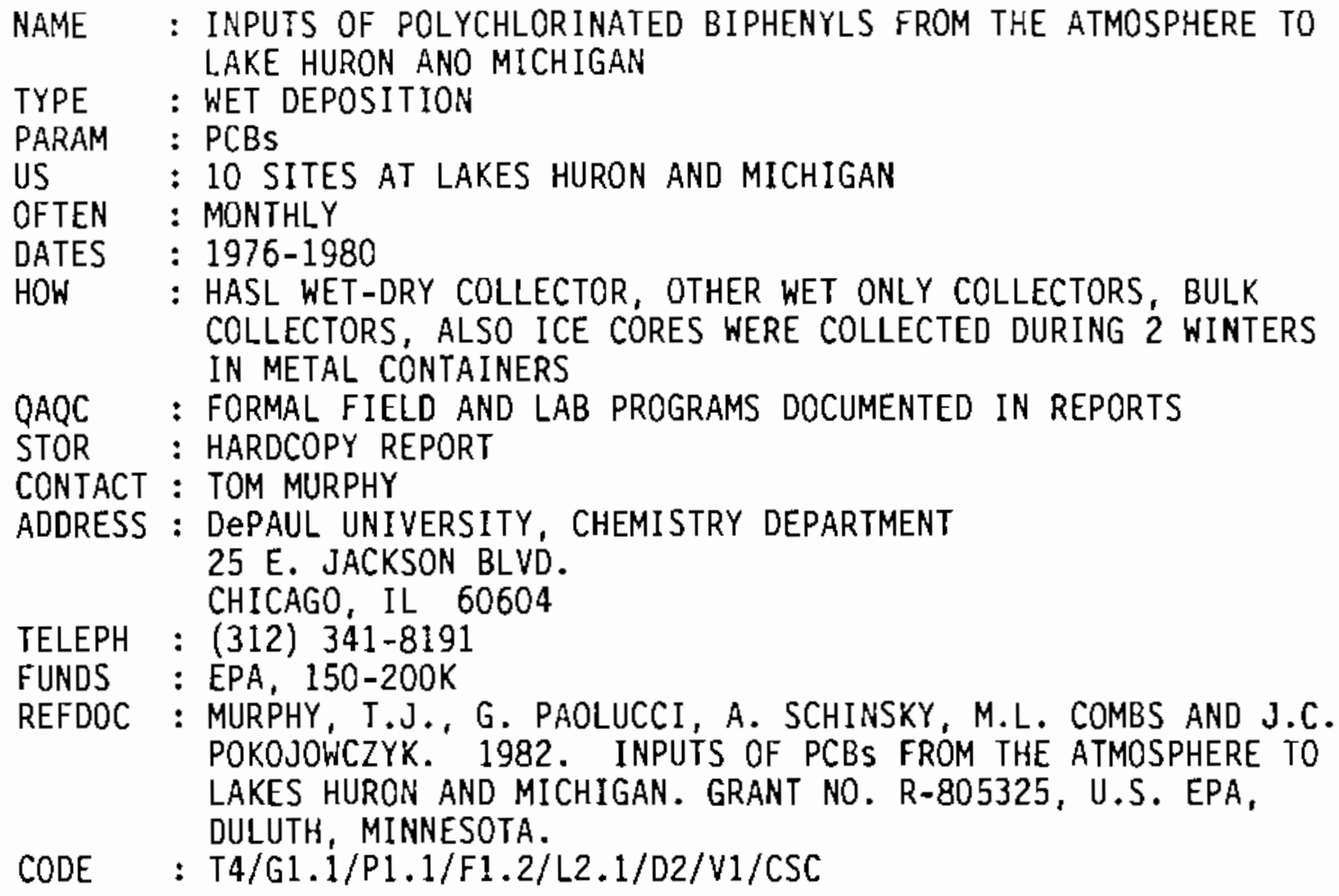




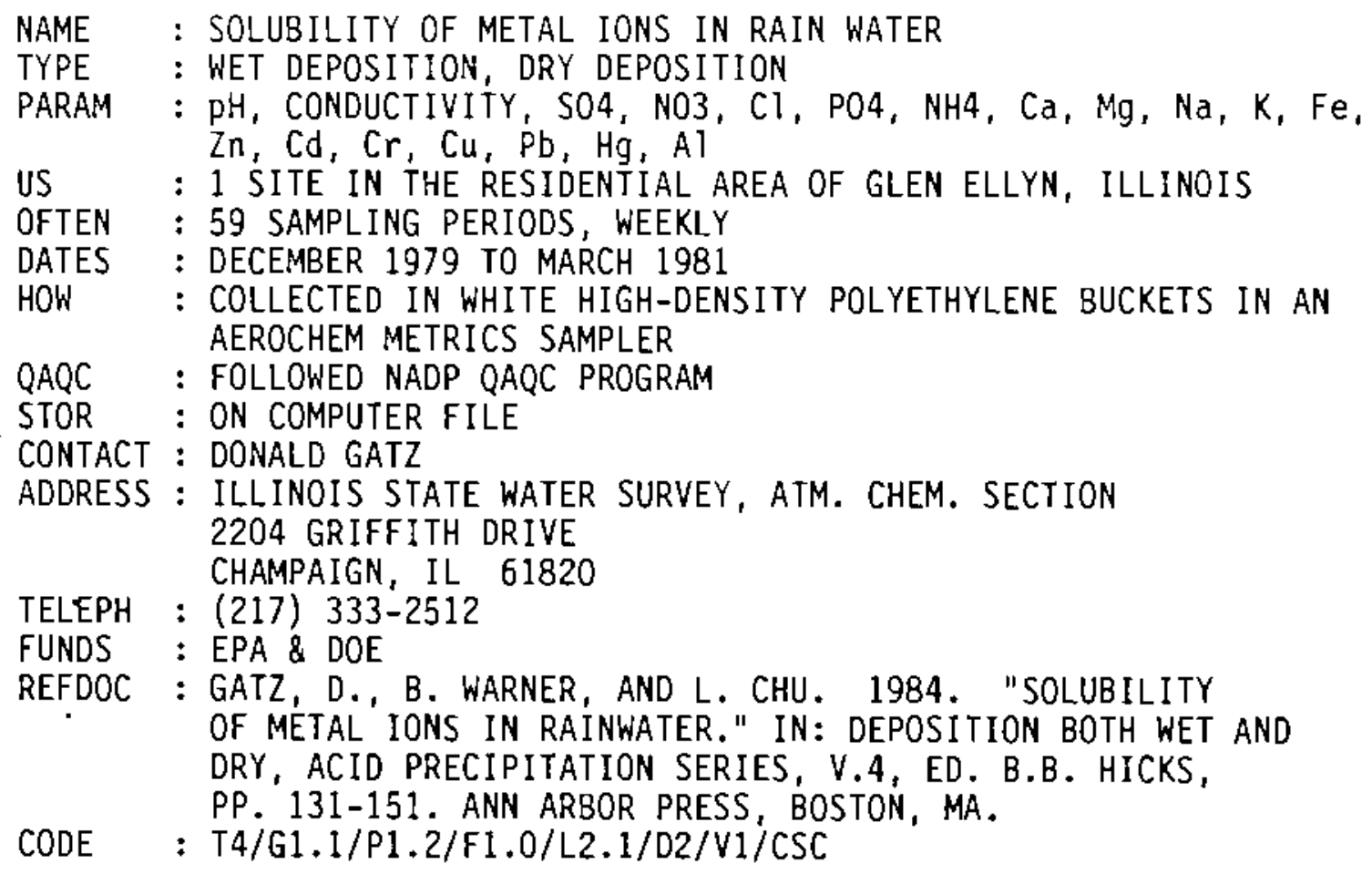




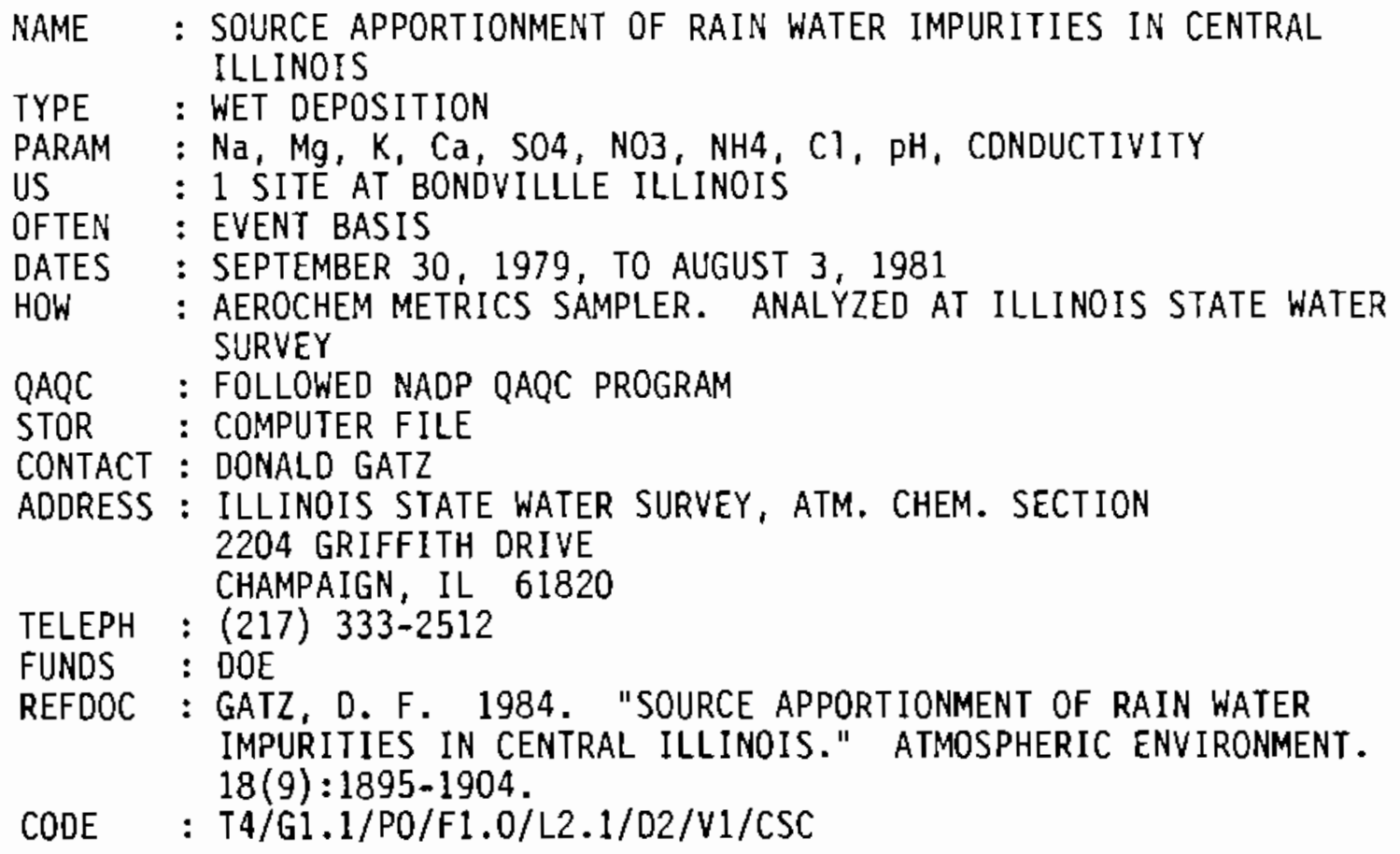




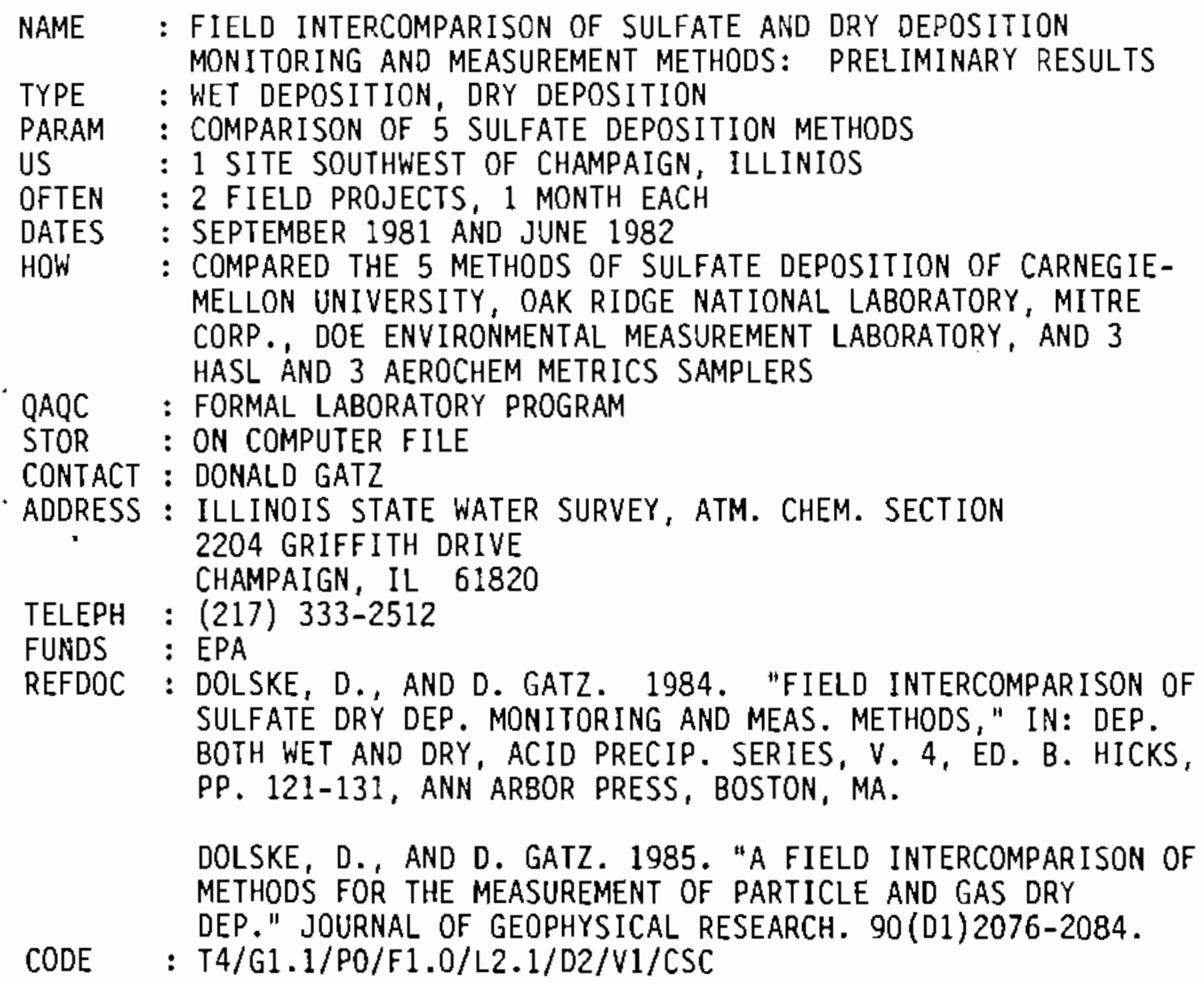




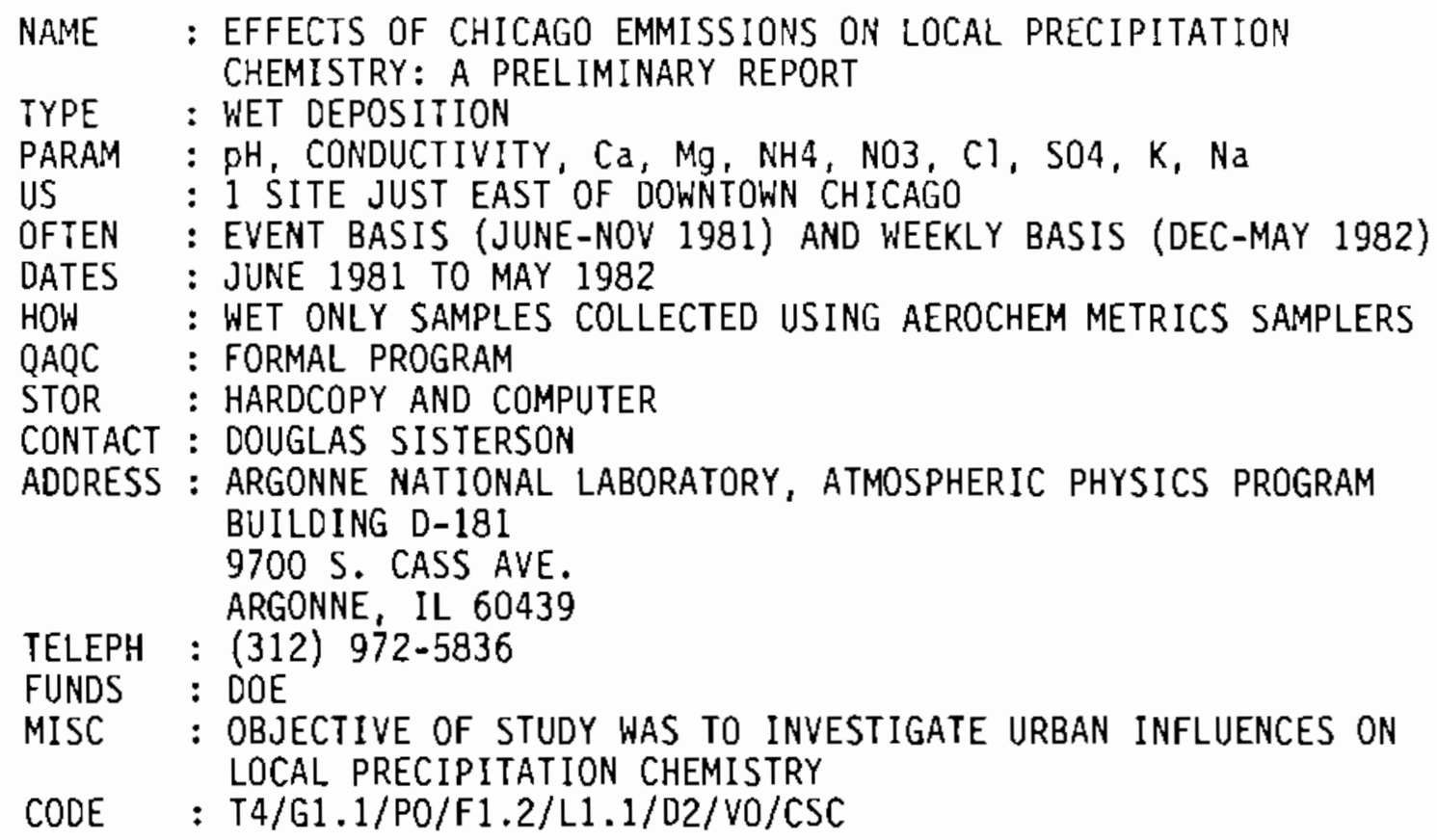




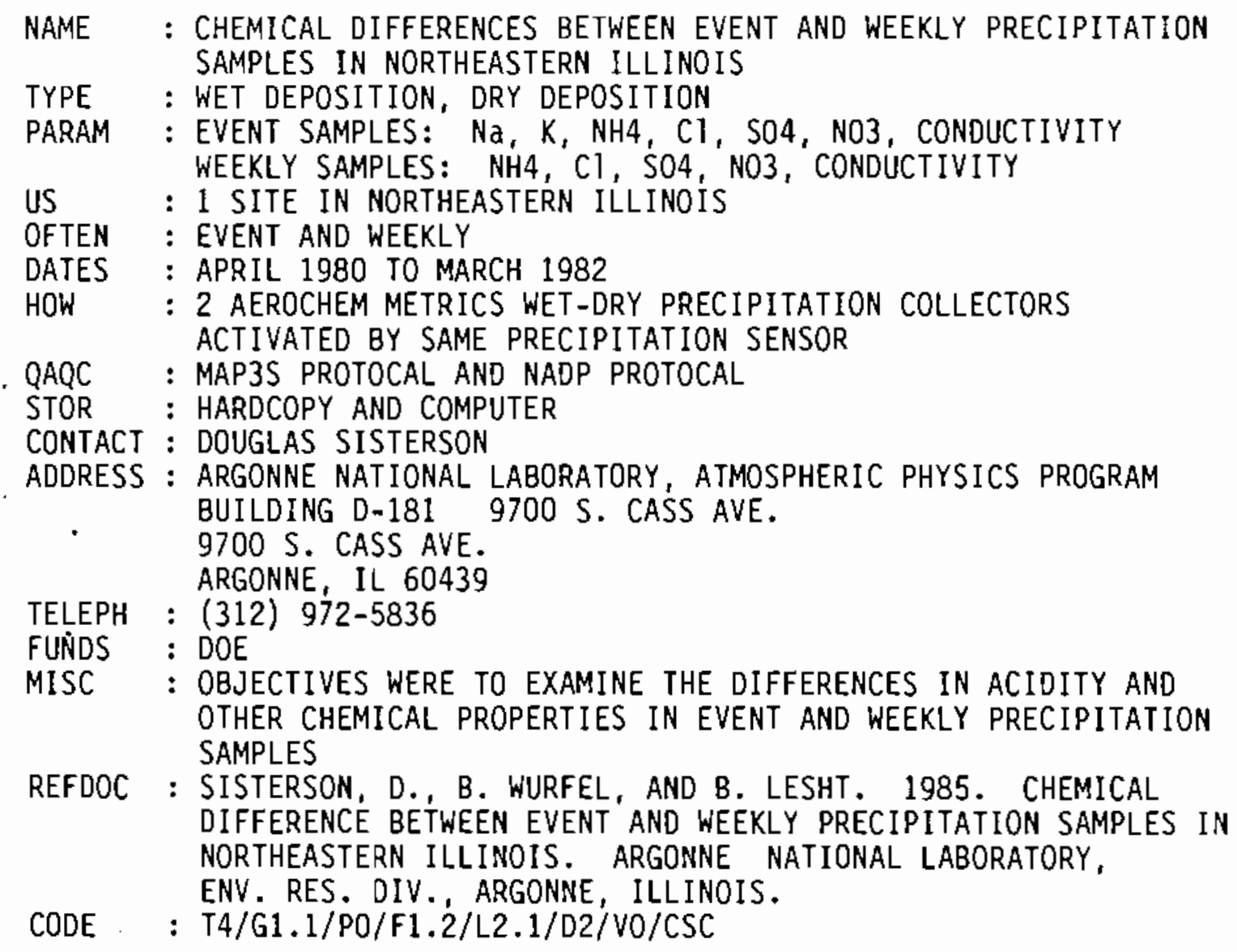

REFDOC : SISTERSON, D., B. WURFEL, AND B. LESHT. 1985. CHEMICAL DIFFERENCE BETWEEN EVENT AND WEEKLY PRECIPITATION SAMPLES IN NORTHEASTERN ILLINOIS. ARGONNE NATIONAL LABORATORY, ENV. RES. DIV., ARGONNE, ILLINOIS.

CODE : : T4/G1.1/PO/F1.2/L2.1/D2/VO/CSC 


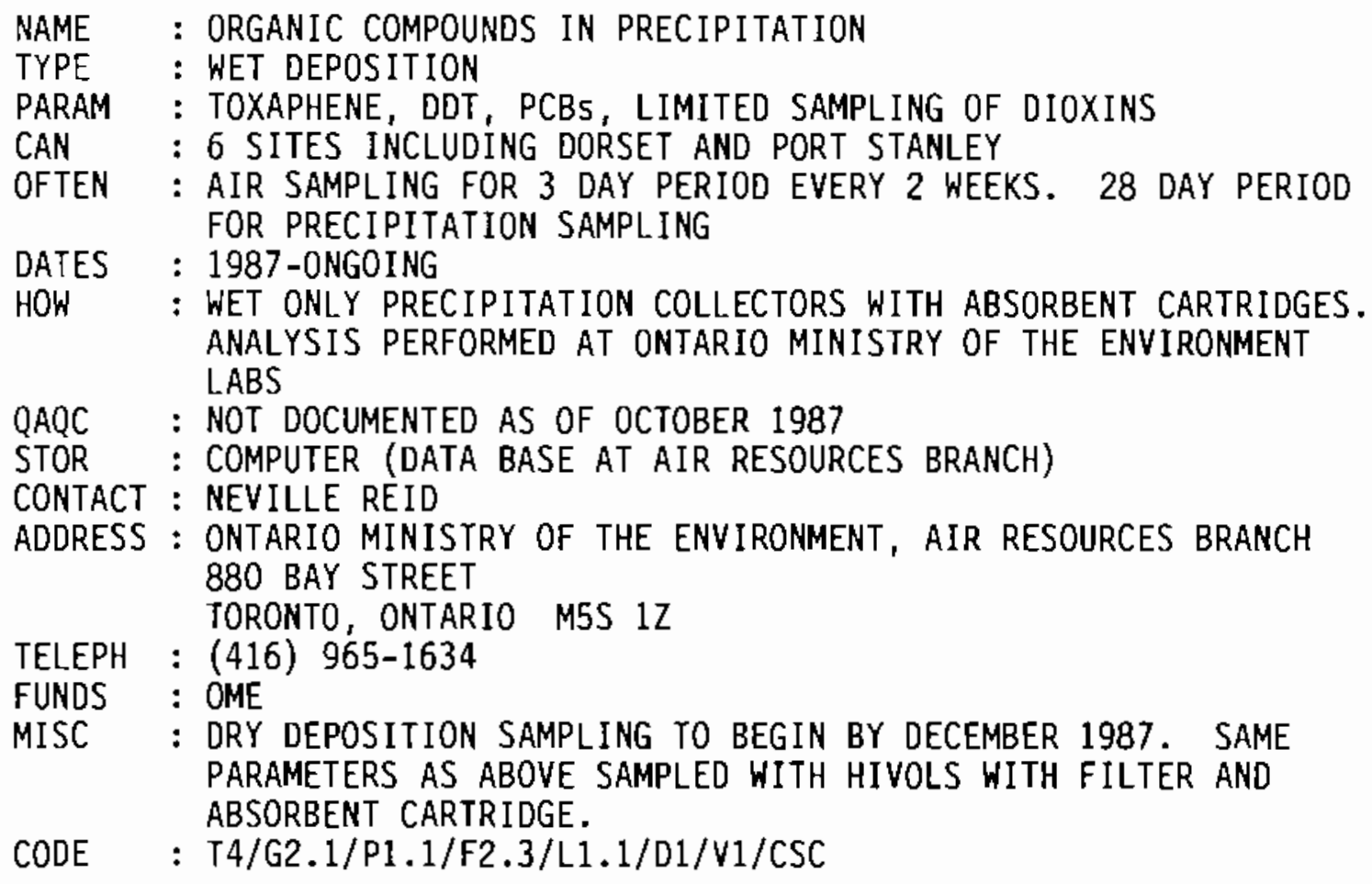




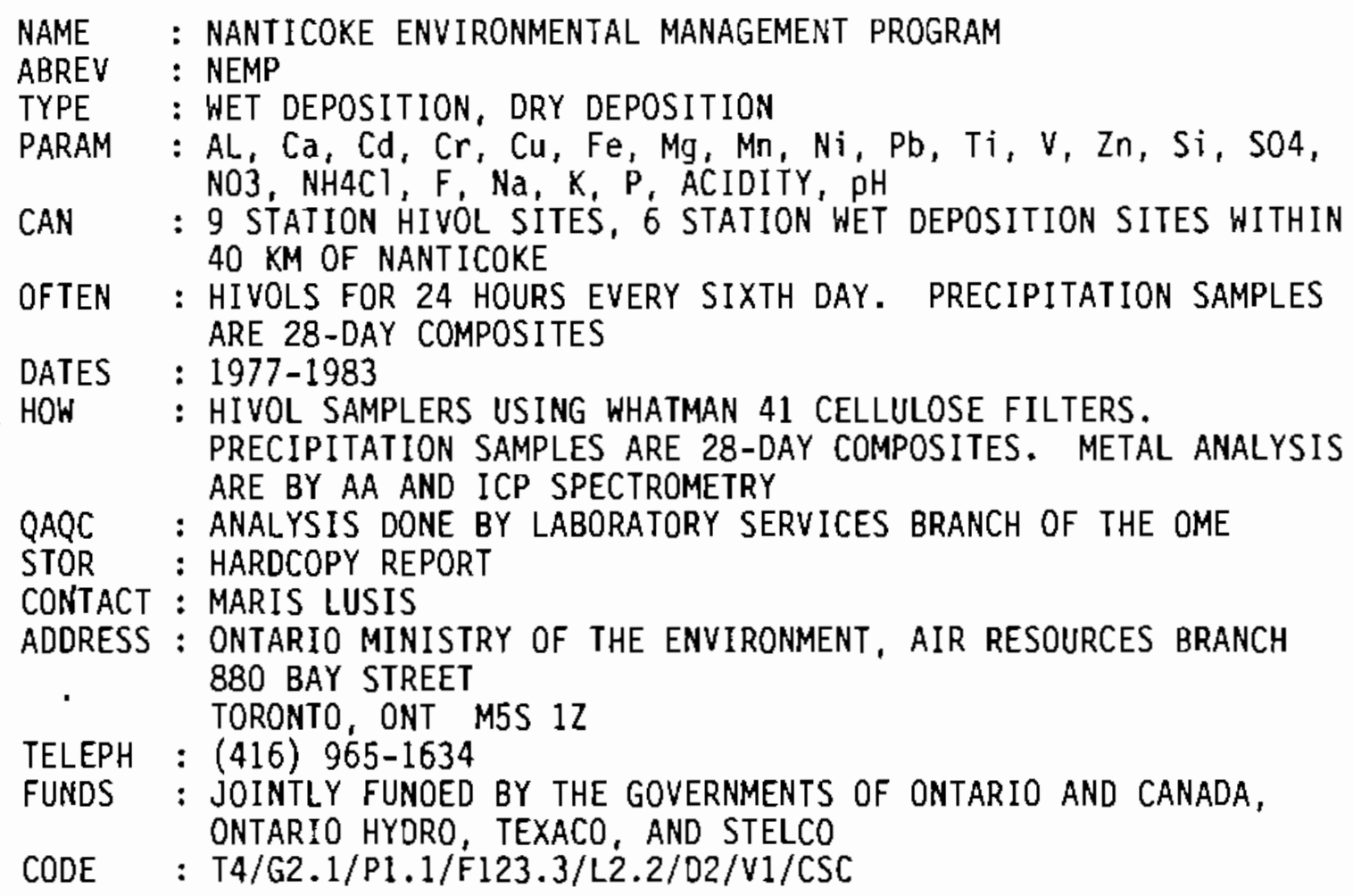




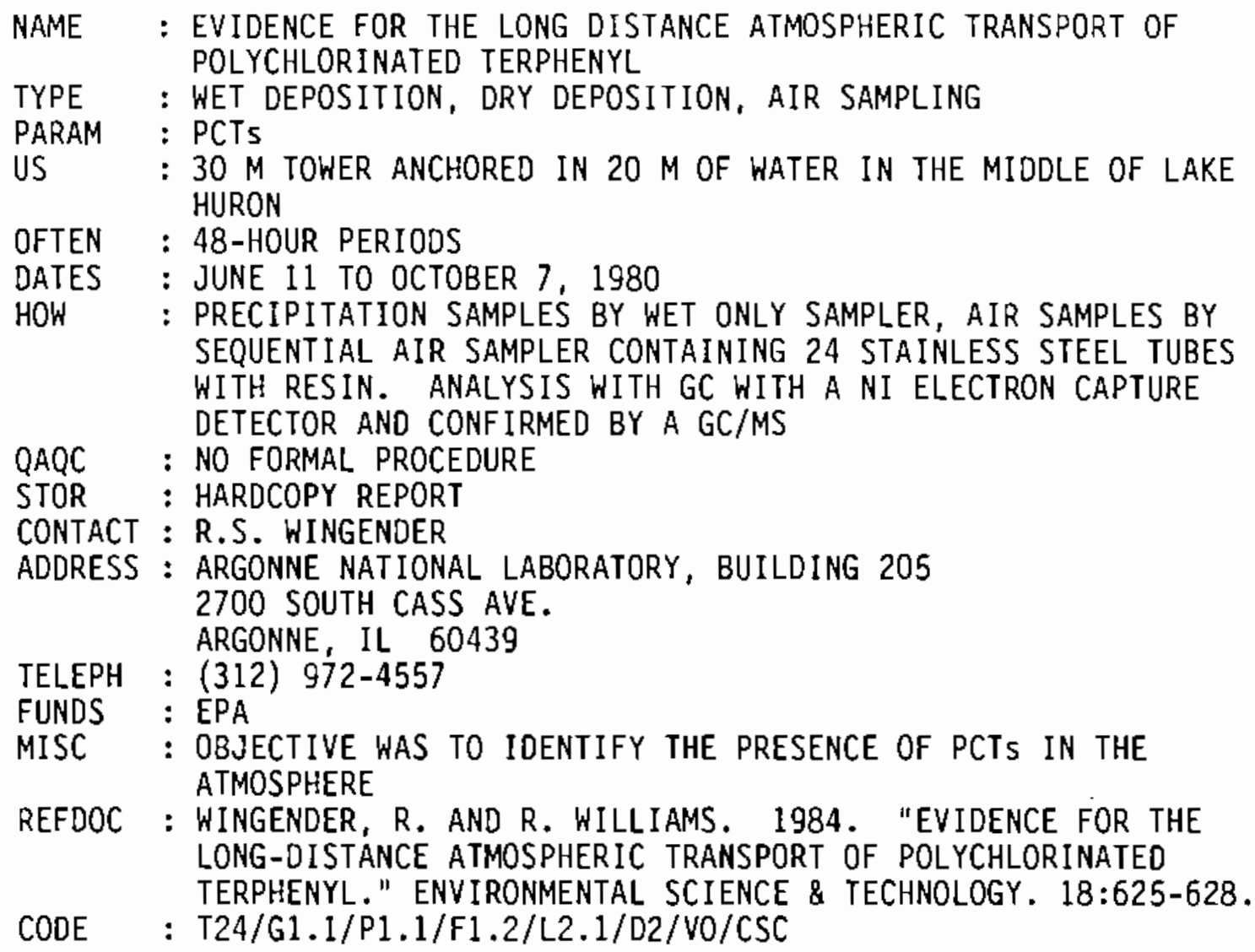




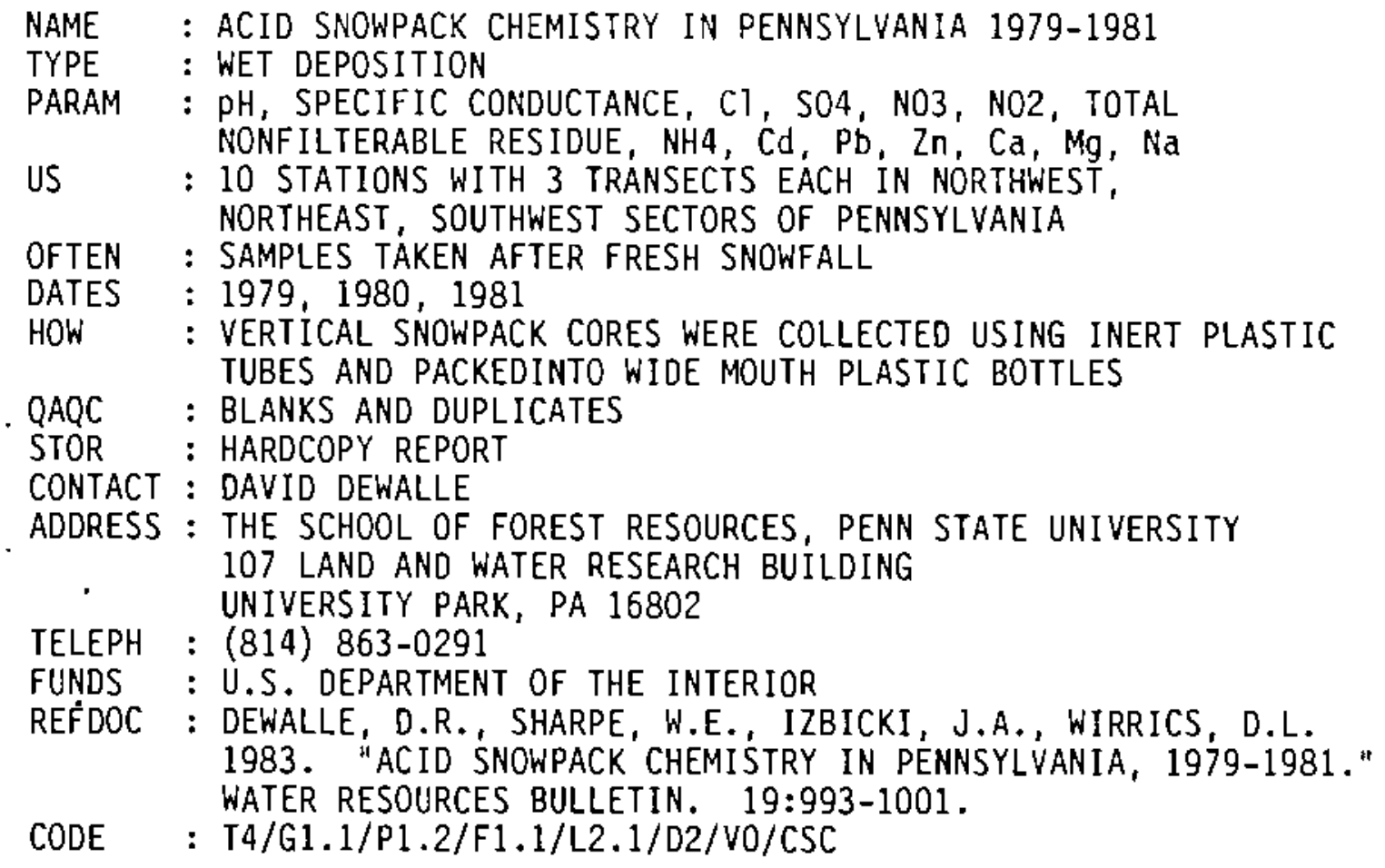




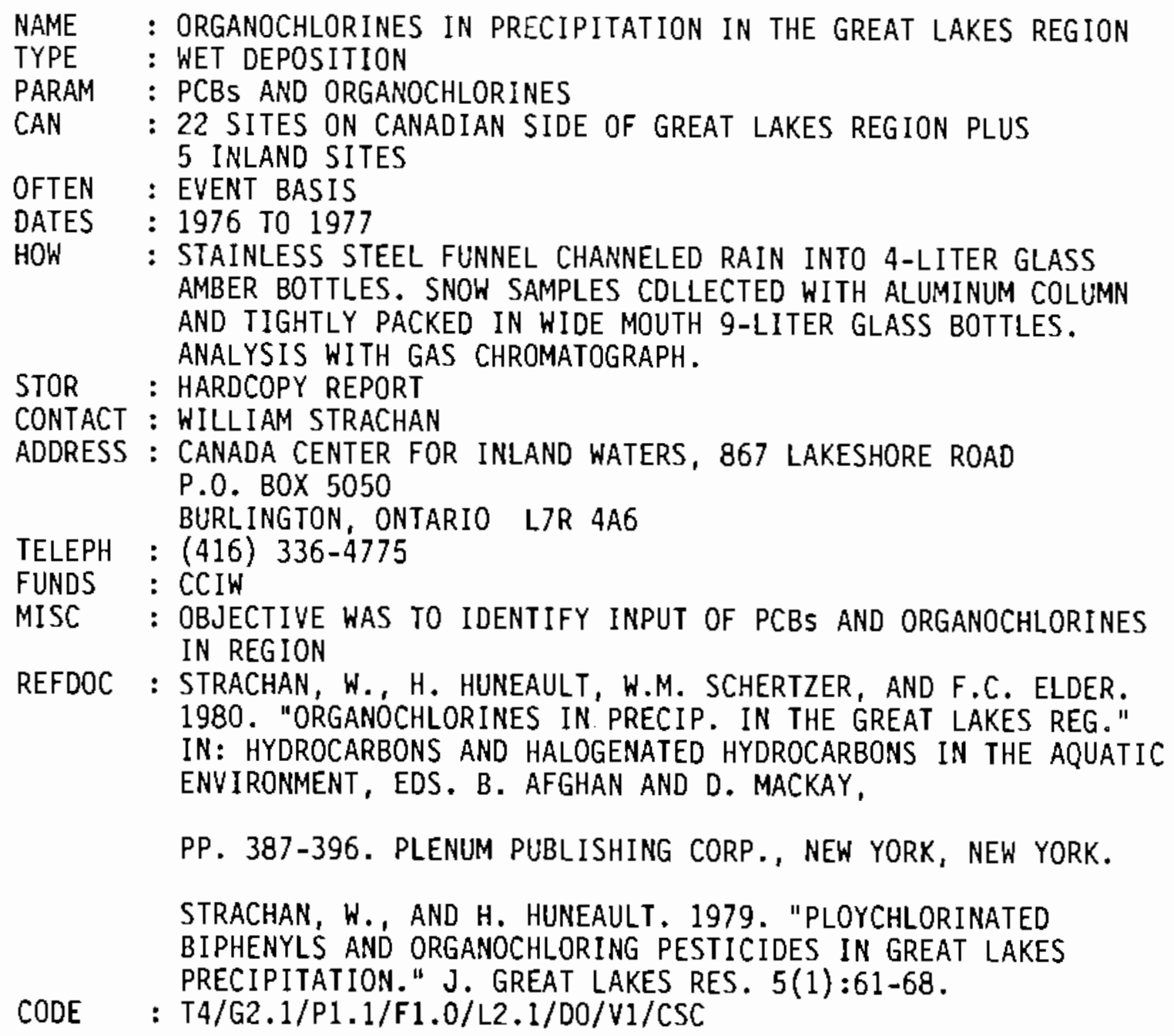




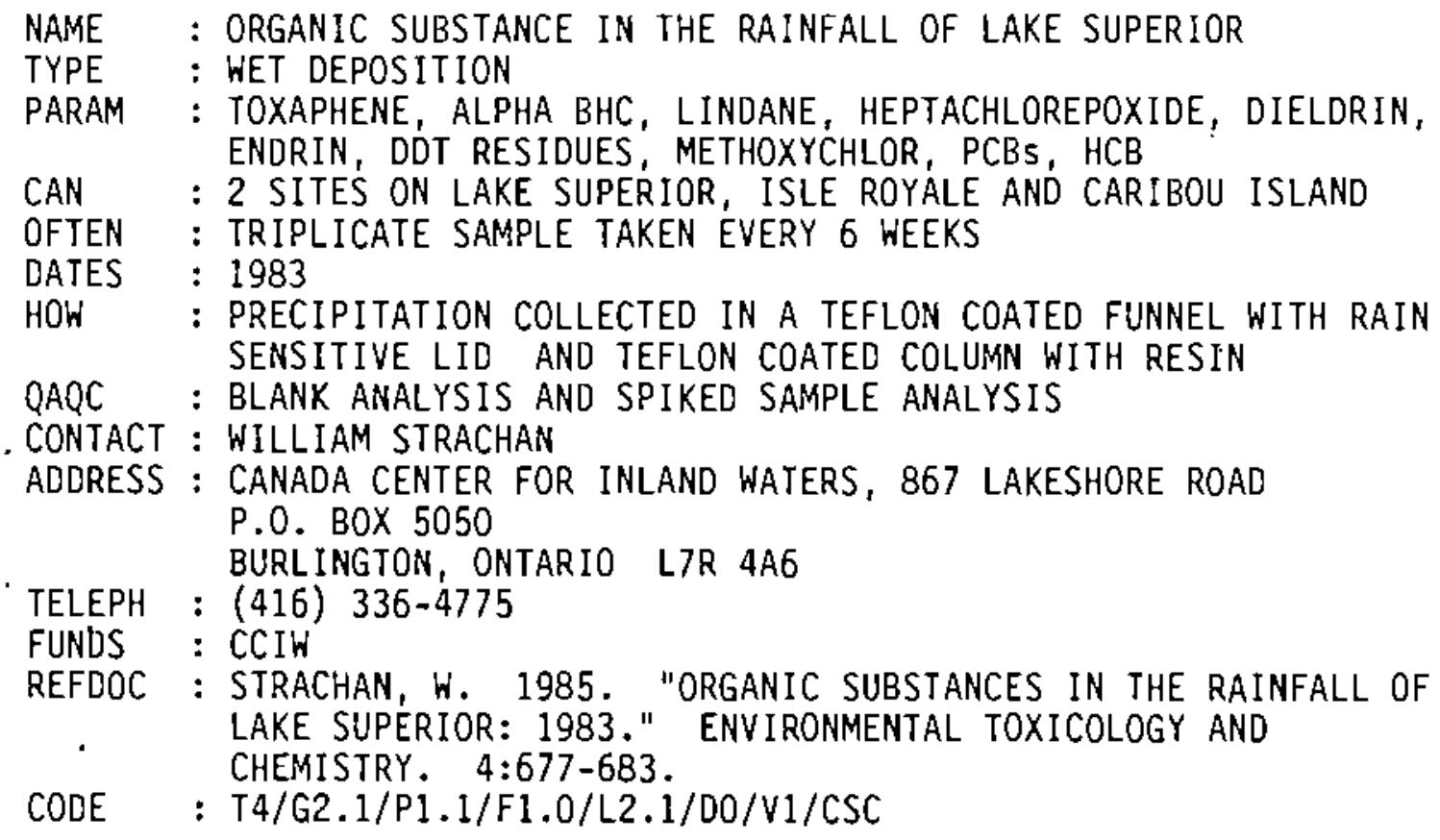




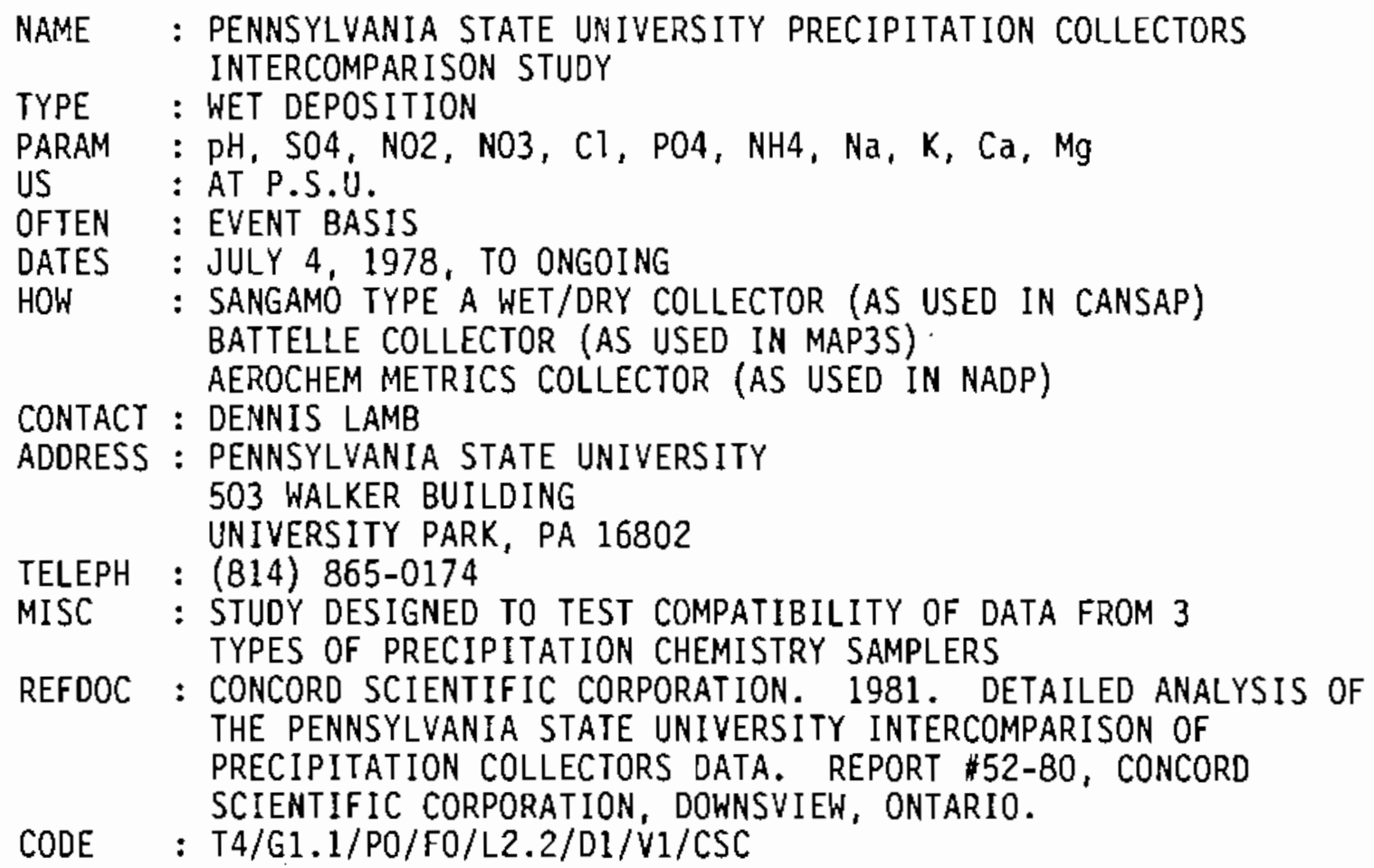


NAME : DEPOSITION OF NUTRIENTS AND MAJOR IONS BY PRECIPITATION IN SOUTH CENTRAL ONTARIO

TYPE : BULK DEPOSITION

PARAM : TOTAL PHOSPHORUS, TKN, N03, NH4, pH, DOC, Si, CONDUCTIVITY, $\mathrm{Fe}, \mathrm{H}, \mathrm{Ca}, \mathrm{Mg}, \mathrm{Na}, \mathrm{K}, \mathrm{SO} 4, \mathrm{Cl}$

CAN $: 8$ SITES IN SOUTH CENTRAL ONTARIO

OFTEN : CUMULATIVE SAMPLES COLLECTED AFTER EVENTS

DATES : AUGUST 1976 TO ONGOING

HOW : COLLECTED WET DEPOSITION WITH BATTERY OPERATED, MOISTURE ACTIVITED SAMPLERS FROM 1976-78. BULK RAIN SAMPLERS USED SINCE 1976 WITH TEFLON COATED STAINLESS STEEL FUNNELS LEADING INTO GLASS BOTTLES.

QAQC : FORMAL PROGRAM

STOR : HP COMPUTER

CONTACT : PETER J. DILLON

ADDRESS : MANAGER, LIMNOLOGY SECTION

ONTARIO MINISTRY OF THE ENVIRONMENT

P.O. BOX 39

DORSET, ONTARIO POA $1 E 0$

TELEPH : (705) 766-2418

FUNDS : OME

REFDOC : SCHEIDER, W.A., W.R. SNYDER AND B. CLARK. 1979. "DEPOSITION OF NUTRIENTS ANO MAJOR IONS BY PRECIPITATION IN SOUTH CENTRAL ONTARIO." WATER AIR AND SOIL POLLUTION. 12:171-185. CODE : T4/G2.1/PO/F2.1/L1.2/D1/V1/CSC 


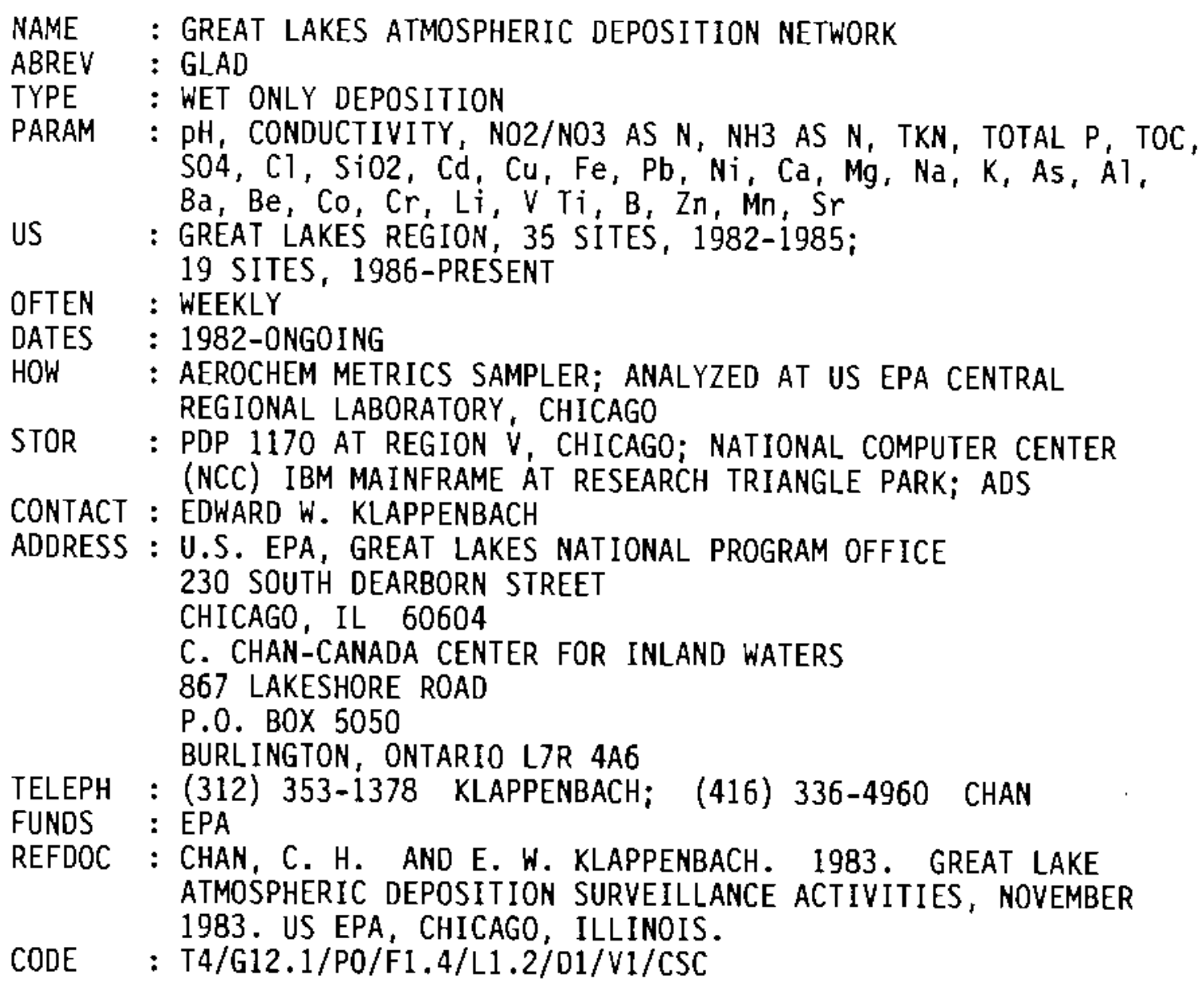




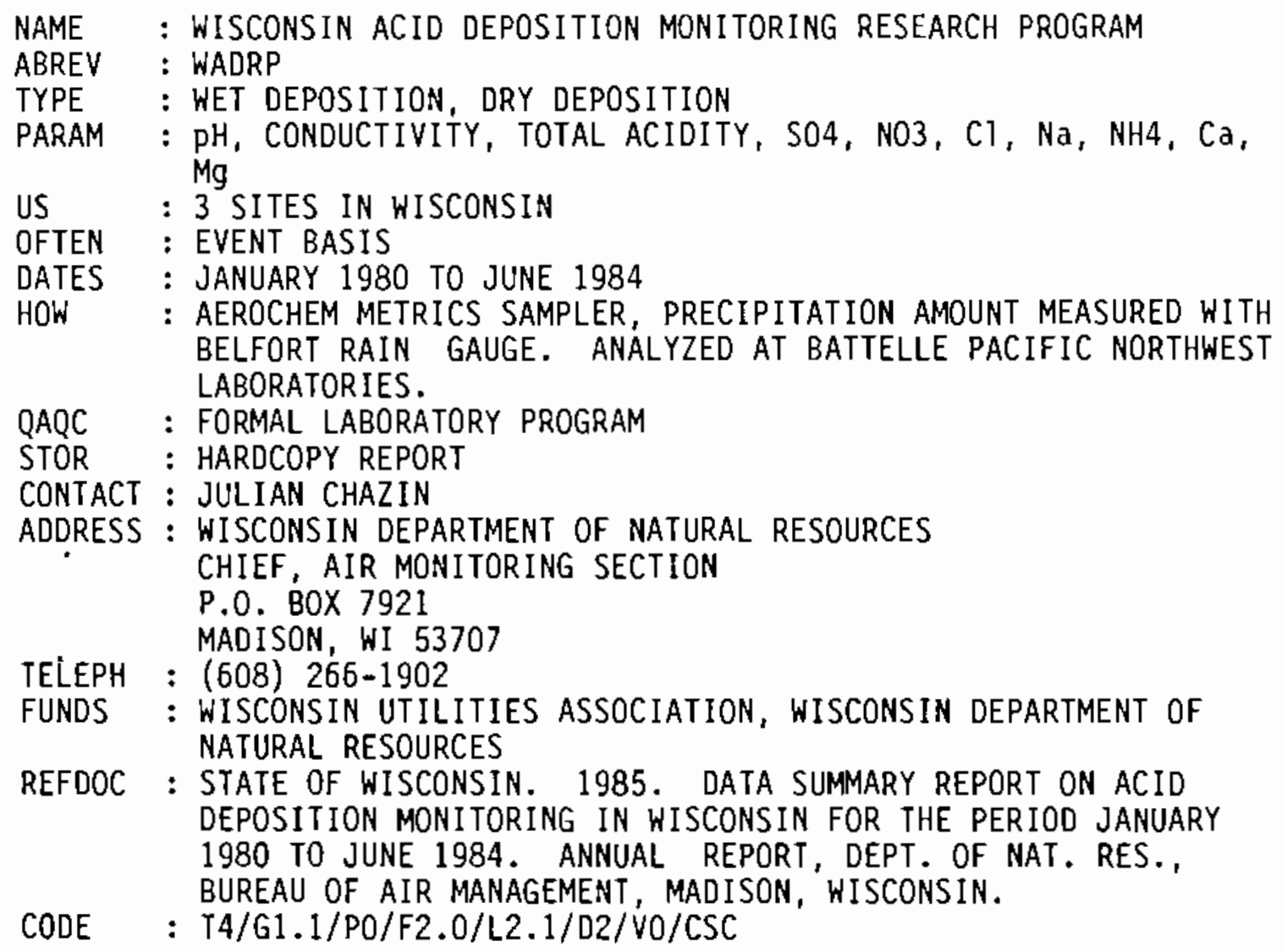




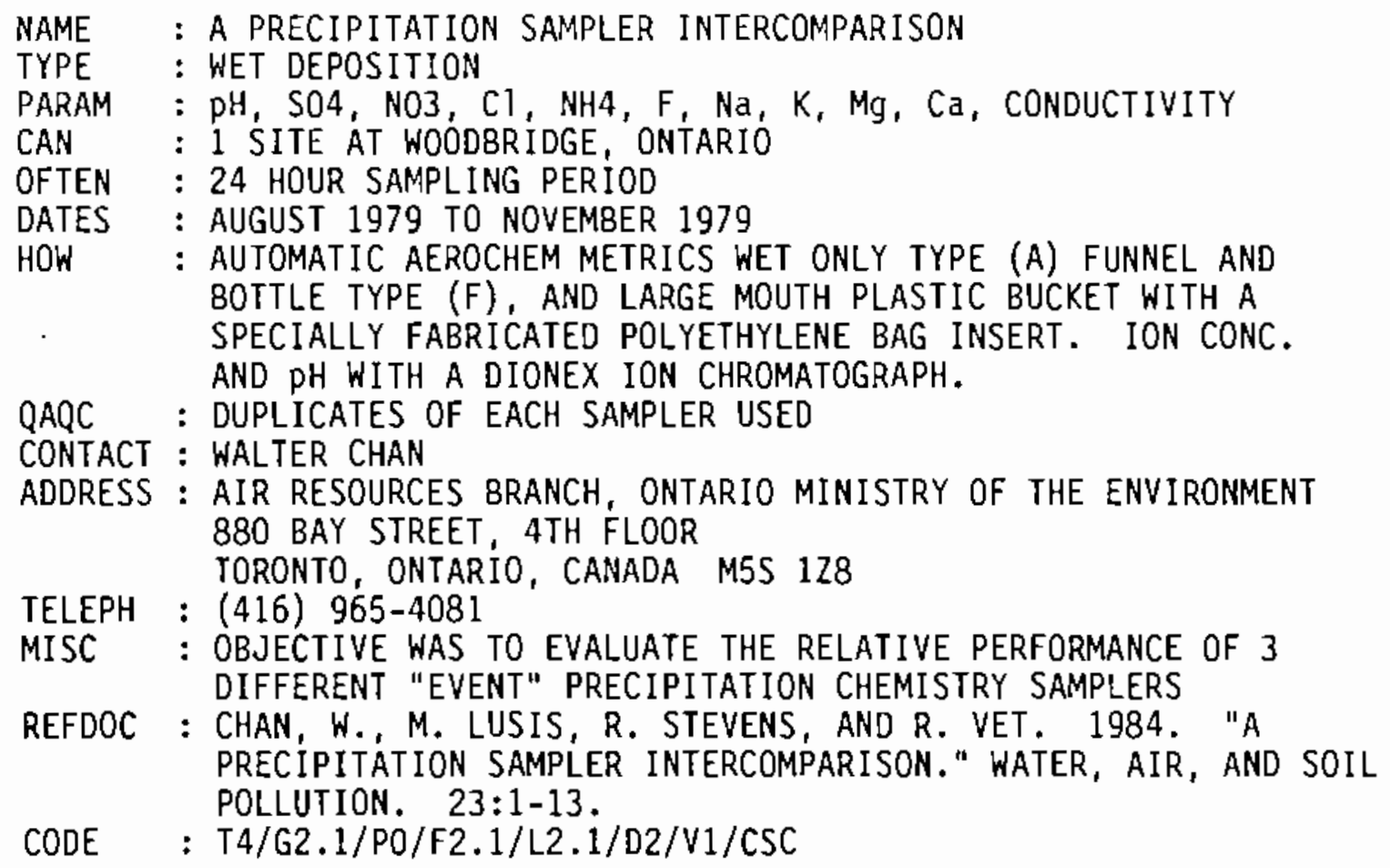




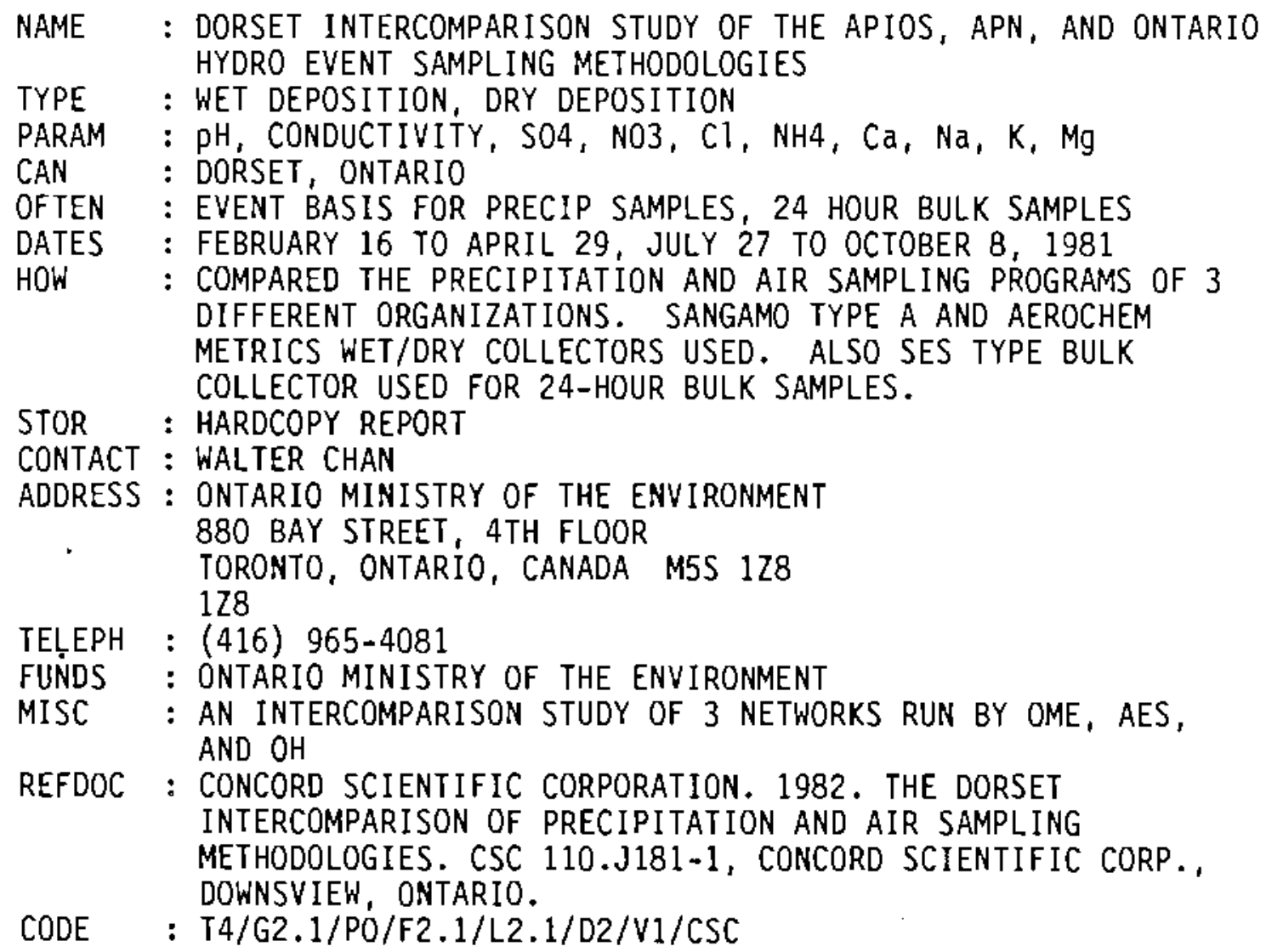

CODE $\quad:$ T4/G2.1/PO/F2.1/L2.1/D2/V1/CSC 


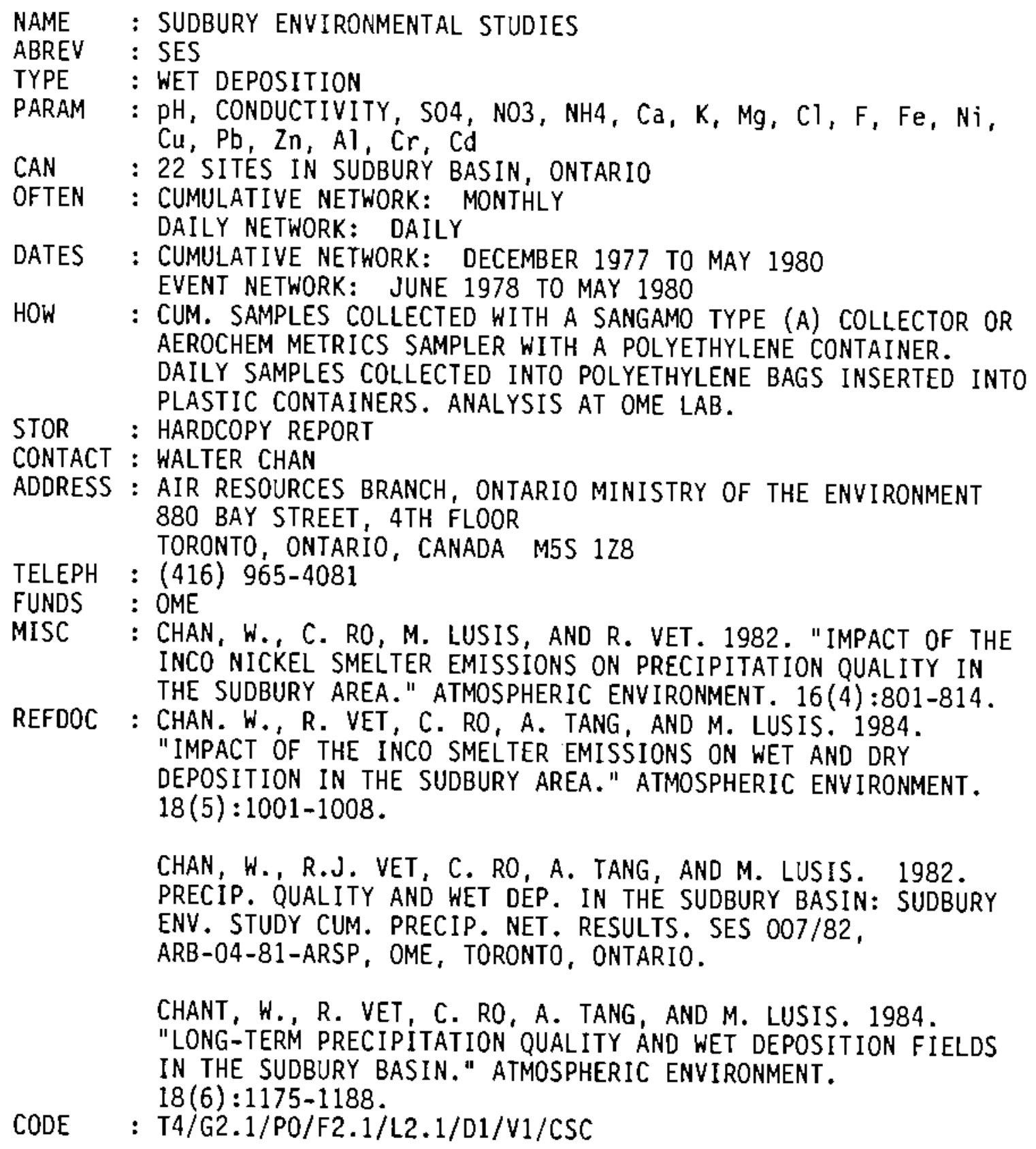




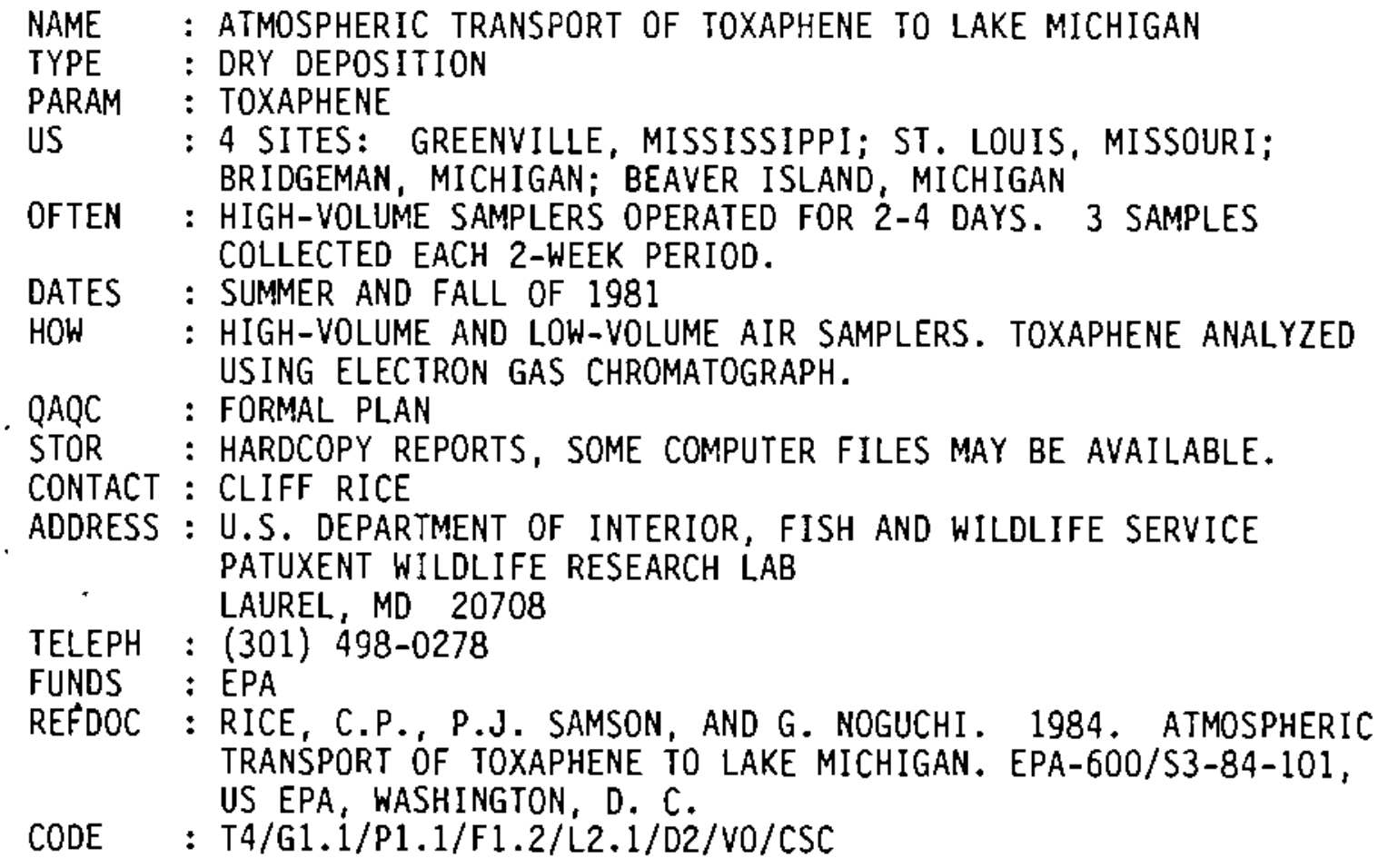




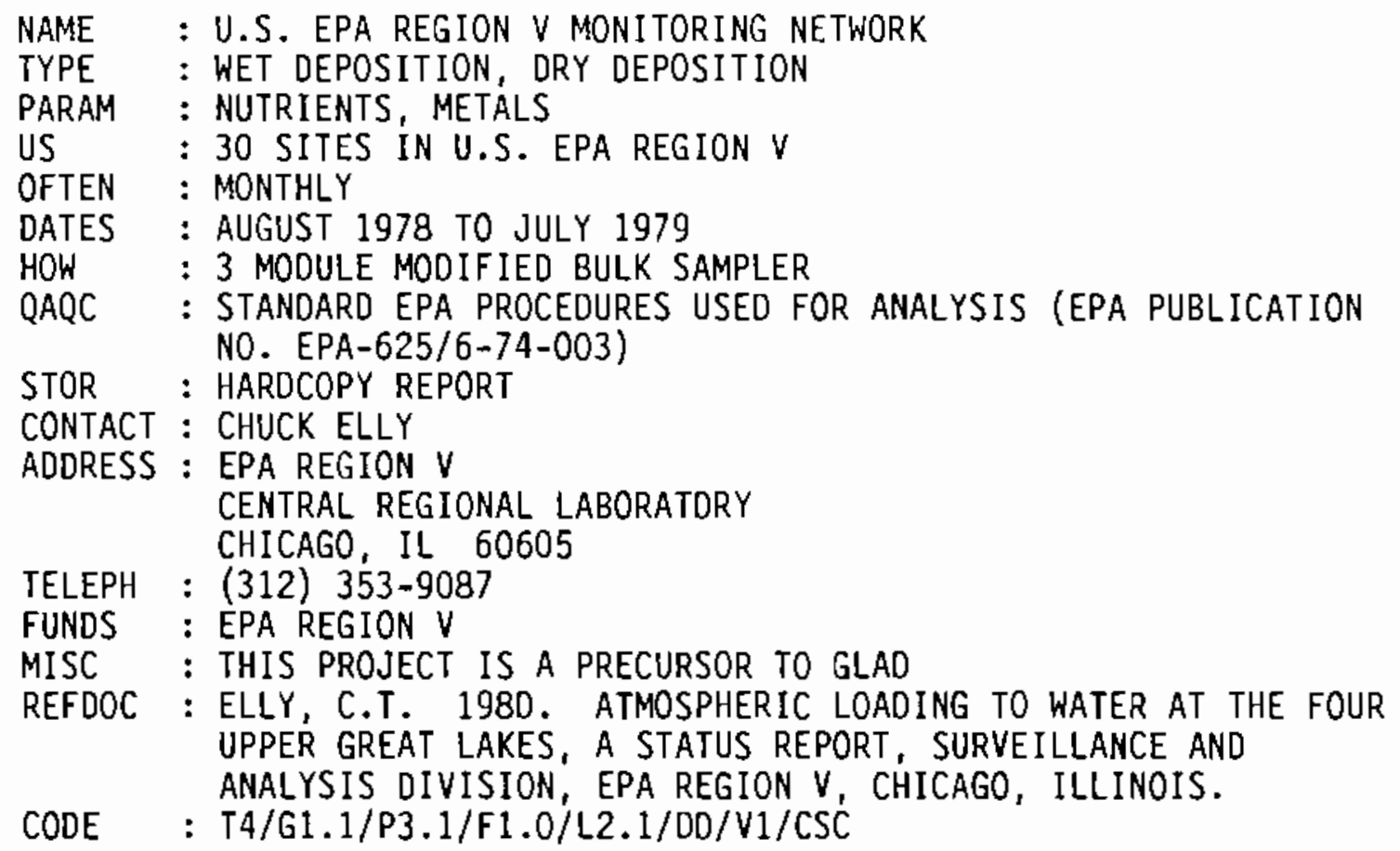




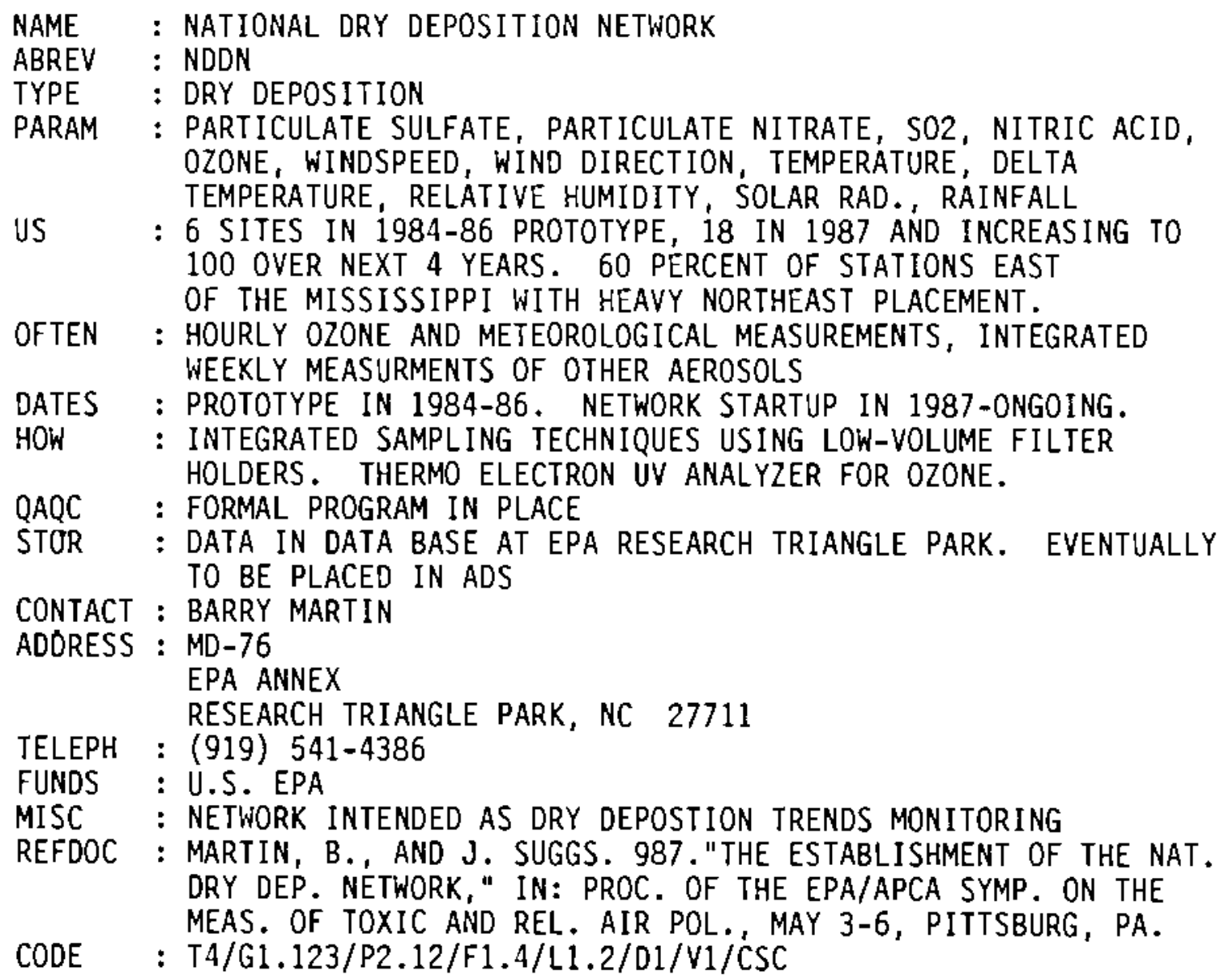




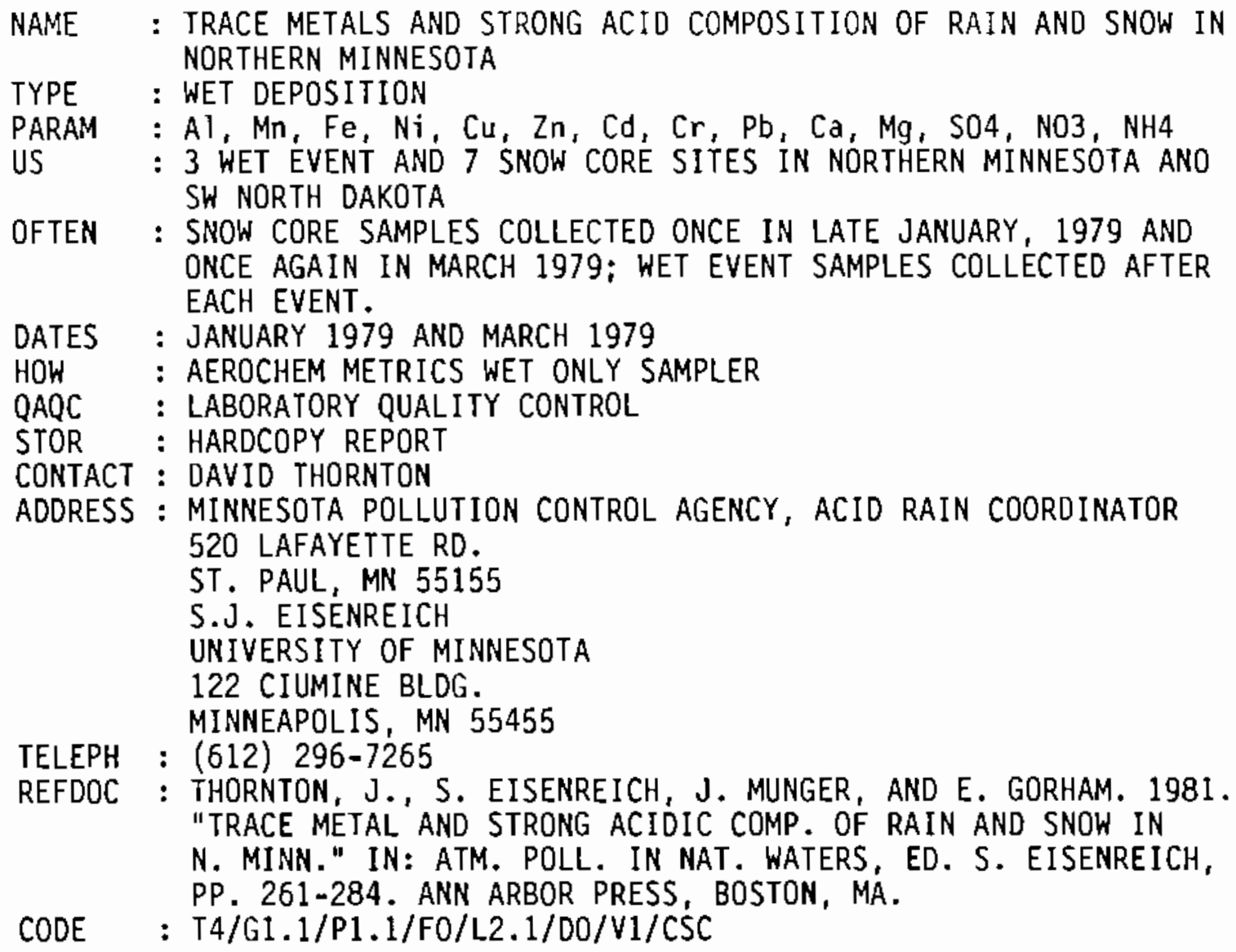




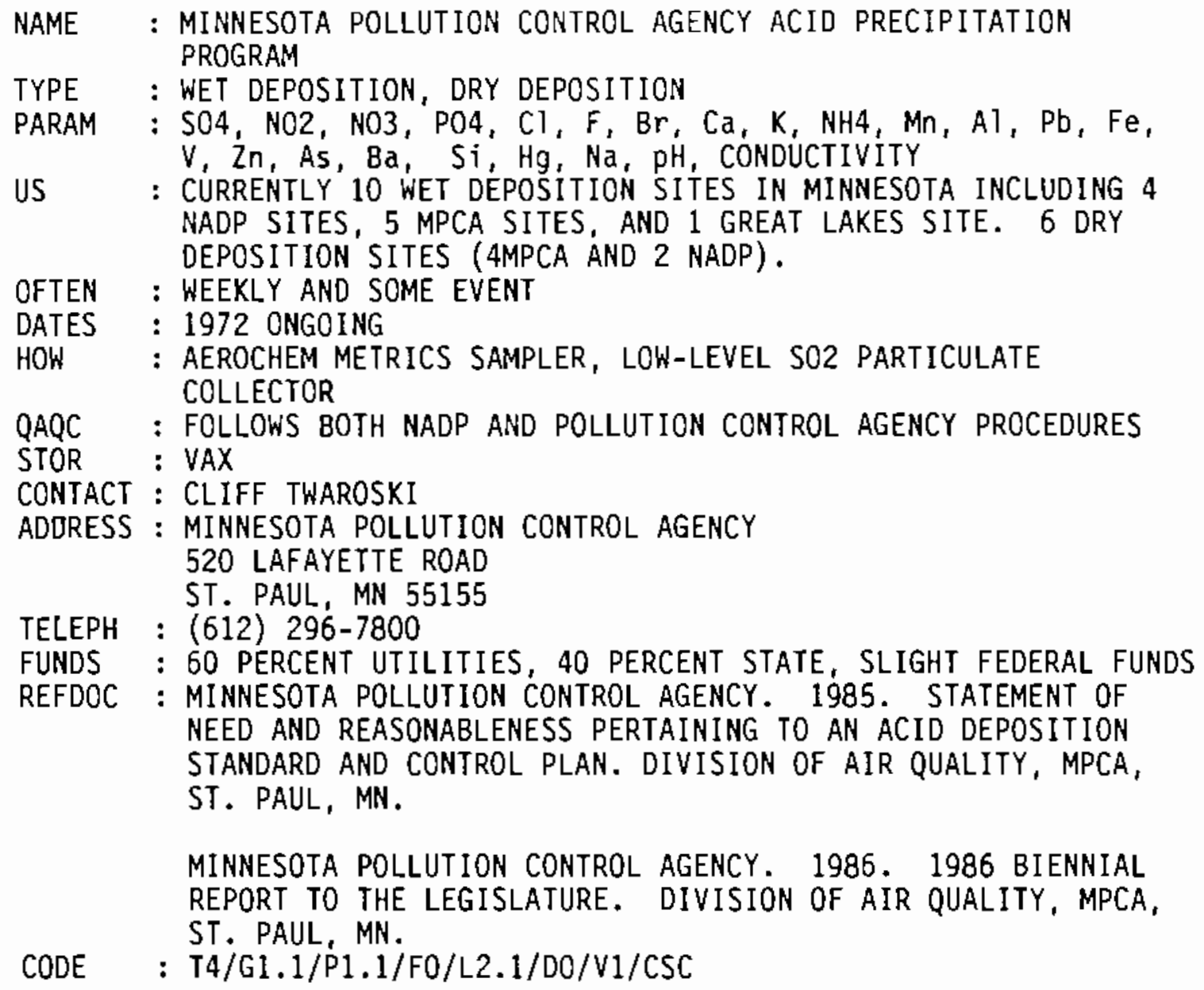




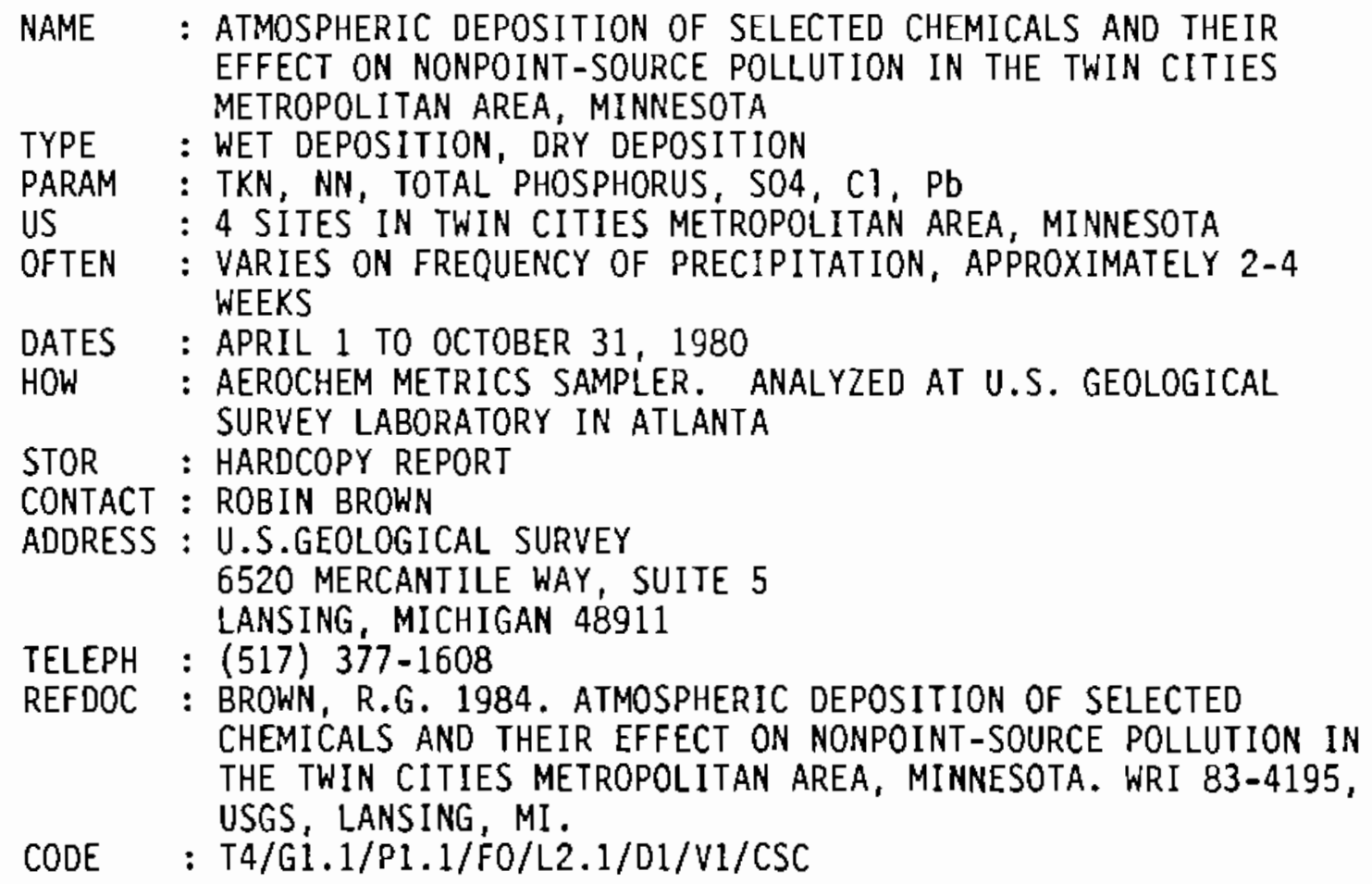




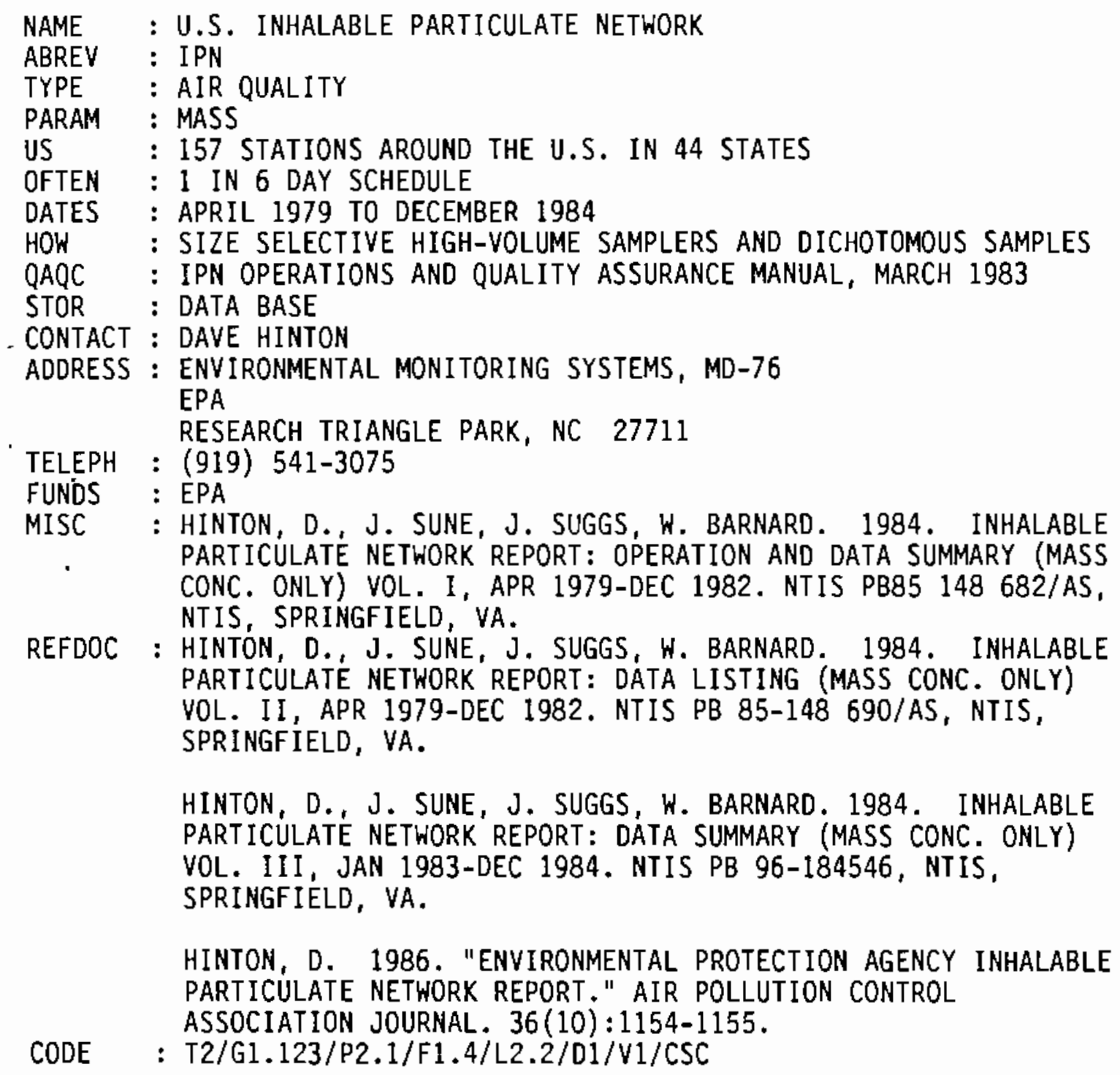

REFDOC : HINTON, D., J. SUNE, J. SUGGS, W. BARNARD. 1984. INHALABLE PARTICULATE NETWORK REPORT: DATA LISTING (MASS CONC. ONLY) VOL. II, APR 1979-DEC 1982. NTIS PB 85-148 690/AS, NTIS, SPRINGFIELD, VA.

HINTON, D., J. SUNE, J. SUGGS, W. BARNARD. 1984 . INHALABLE PARTICULATE NETWORK REPORT: DATA SUMMARY (MASS CONC. ONLY) VOL. III, JAN 1983-DEC 1984. NTIS PB 96-184546, NTIS, SPRINGFIELD, VA.

HINTON, D. 1986. "ENVIRONMENTAL PROTECTION AGENCY INHALABLE PARTICULATE NETWORK REPORT." AIR POLLUTION CONTROL

ASSOCIATION JOURNAL. 36(10):1154-1155.

CODE : T2/G1.123/P2.1/F1.4/L2.2/D1/V1/CSC 


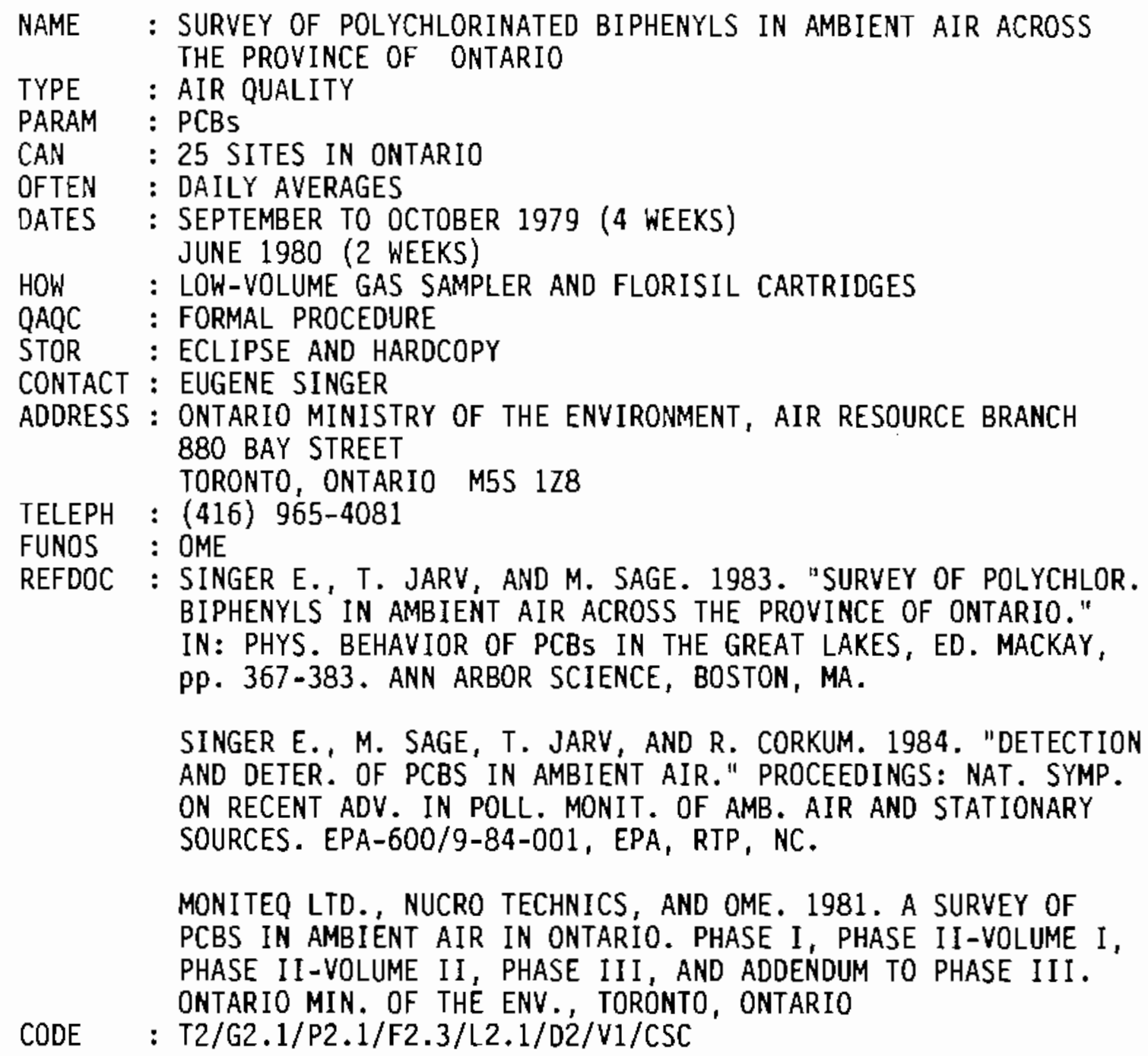




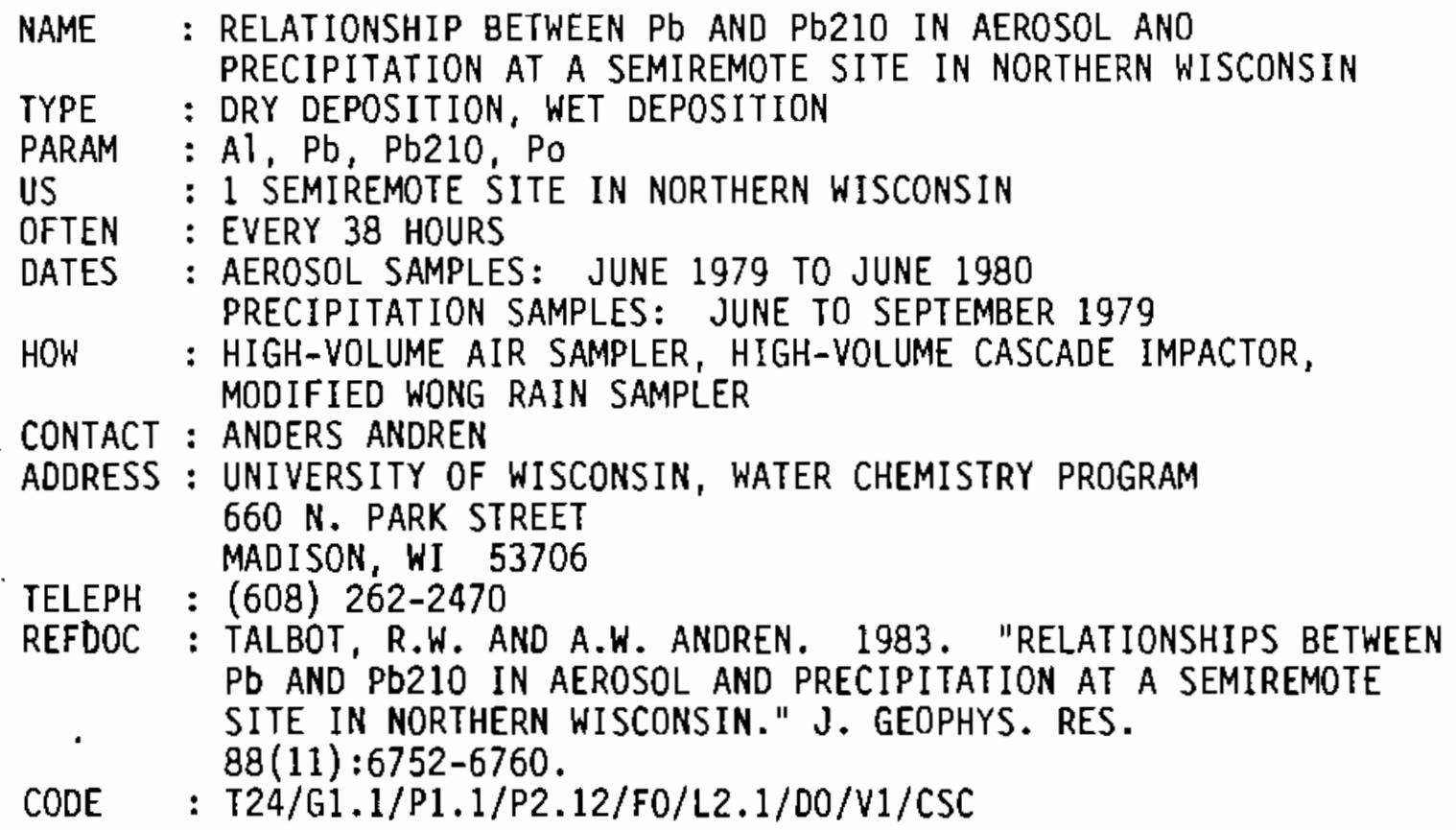




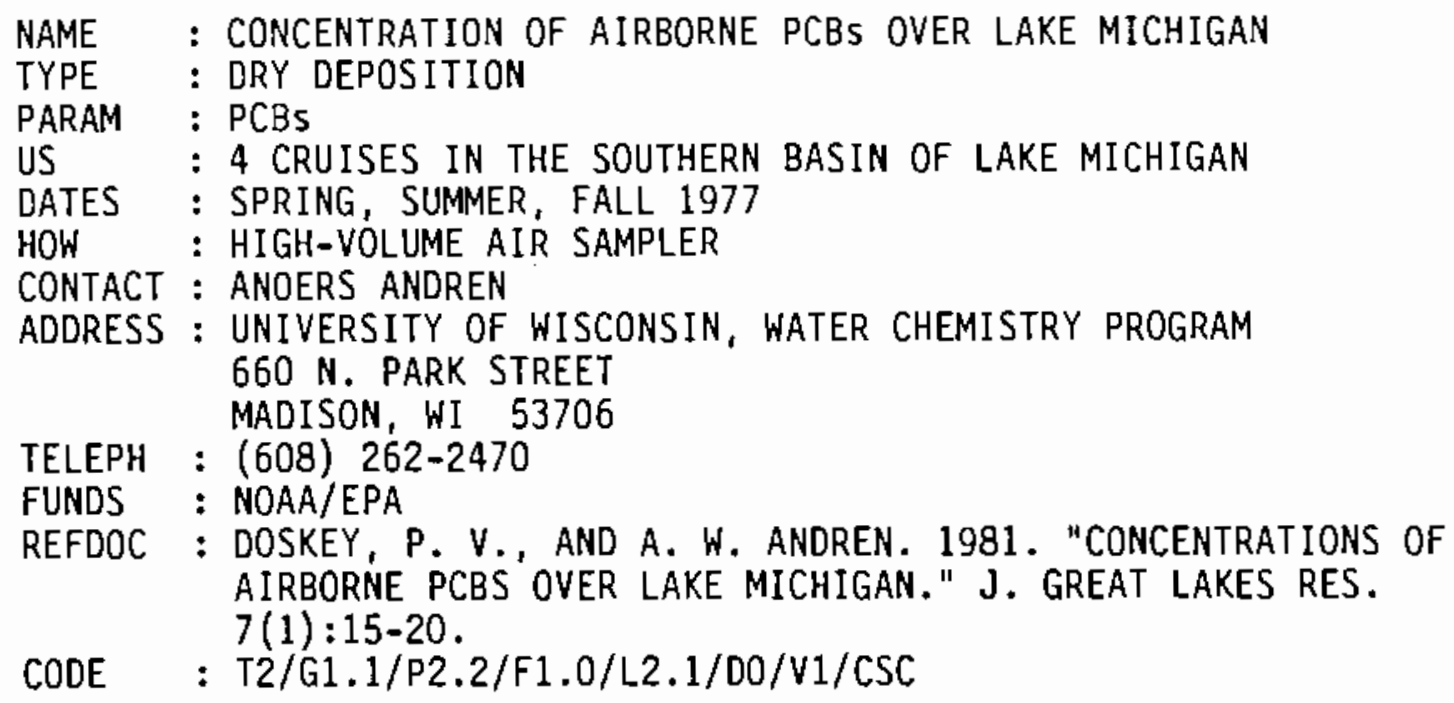




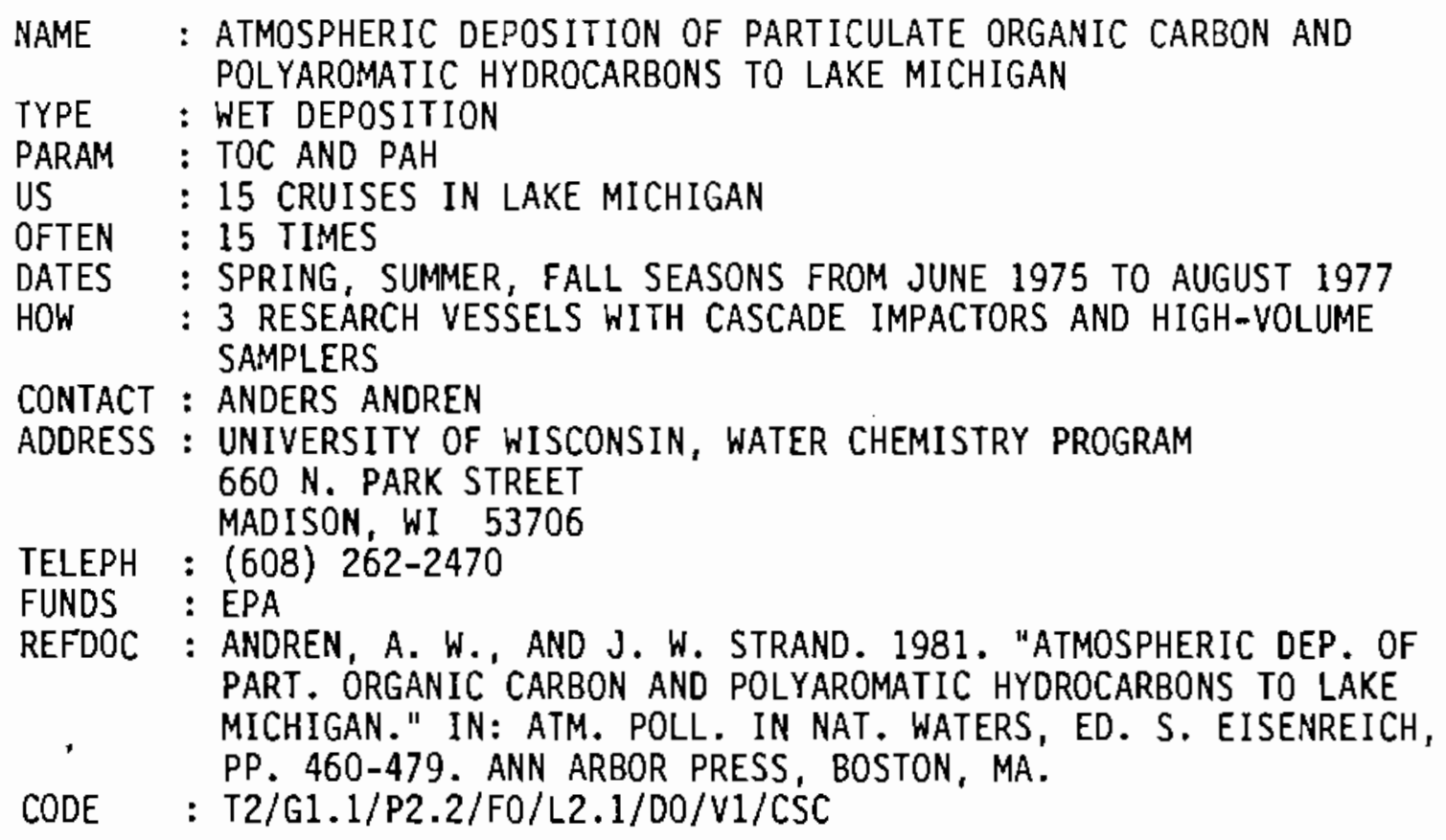


NAME : NEW YORK STATE AIR MONITORING NETWORK - ACID DEPOSITION

TYPE : WET DEPOSITION

PARAM : $\mathrm{pH}$, CONDUCTIVITY, $\mathrm{F}, \mathrm{Cl}, \mathrm{NO2}, \mathrm{NO3}, \mathrm{HPO4}, \mathrm{Br}, \mathrm{SO} 4, \mathrm{Na}, \mathrm{K}, \mathrm{NH4}$, $\mathrm{Ca}, \mathrm{Mg}$

US : 13 SITES IN NEW YORK

OFTEN : WEEKLY

DATES : 1986

HOW : WET/DRY COLLECTOR

QAQC : FORMAL WRITTEN QA/QC PROGRAM

STOR : DATA ON HARD COPY AND PC (AS OF 10/87). WILL BE ON MAINFRAME COMPUTER EVENTUALLY

CONTACT : DONALD GOWER

ADDRESS : NEW YORK STATE DEPARTMENT OF ENVIRONMENTAL CONSERVATION 50 WOLF ROAD, RM. 140

ALBANY, NY 12233-3256

TELEPH : (518) 457-3676

FUNDS : NEW YORK STATE

MISC : NETWORK WILL BE EXPANDED TO 25 STATIONS LOCATED ACROSS THE STATE. CONTINUOUS GASEOUS SAMPLERS AND METEOROLOGICAL INSTRUMENTS TO BE ADDED IN 1988. FUTURE PLANS TO MEASURE OR CALCULATE DRYFALL AND MEASURE VISIBILITY.

CODE $\quad:$ T4 $/$ G1.1/P3.12/F2.4/L1/D1/V1/CSC 
NAME : USGS NEW YORK STATE PRECIPITATION MONITORING NETWORK

TYPE : WET DEPOSITION, DRY DEPOSITION

PARAM : $\mathrm{Na}, \mathrm{K}, \mathrm{Ca}, \mathrm{Mg}, \mathrm{pH}, \mathrm{NH} 4, \mathrm{NO3}, \mathrm{NO2}, \mathrm{Cl}, \mathrm{SO} 4, \mathrm{HCO}$, CONDUCTIVITY

US $\quad 9$ SITES; 8 IN NEW YORK, 1 IN PENNSYLVANIA NEAR NEW YORK BORDER

DATES : 1965 TO 1977

HOW : GLASS FUNNEL INTO A PLOYETHYLENE BUCKET

STOR : HAROCOPY REPORT

CONTACT : CHUCK BARNES

ADDRESS : USGS

P.0. BOX 1397

ALBANY, NY 12201

TELEPH : (518) $472-2453$

FUNDS : USGS

REFDOC : PETERS, N.E., R.A. SCHROEDER, AND D.E. TROUTMAN. 1982. TEMPORAL TRENDS IN THE ACIDITY OF PRECIPITATION AND SURFACE WATERS OF NEW YORK. USGS WATER SUPPLY PAPER 2188, USGS, ALBANY, NY.

BARNES, C.R., R.A. SCHROEDER, AND N.E. PETERS. 1982.

"CHANGES IN THE CHEMISTRY OF BULK PRECIPITATION IN NEW YORK STATE, 1965-78." NORTHEASTERN ENVIRONMENT SCIENCE $1: 187-197$.

CODE $\quad:$ T4/G1.1/PO/F1.0/L2.2/D2/VO/CSC 


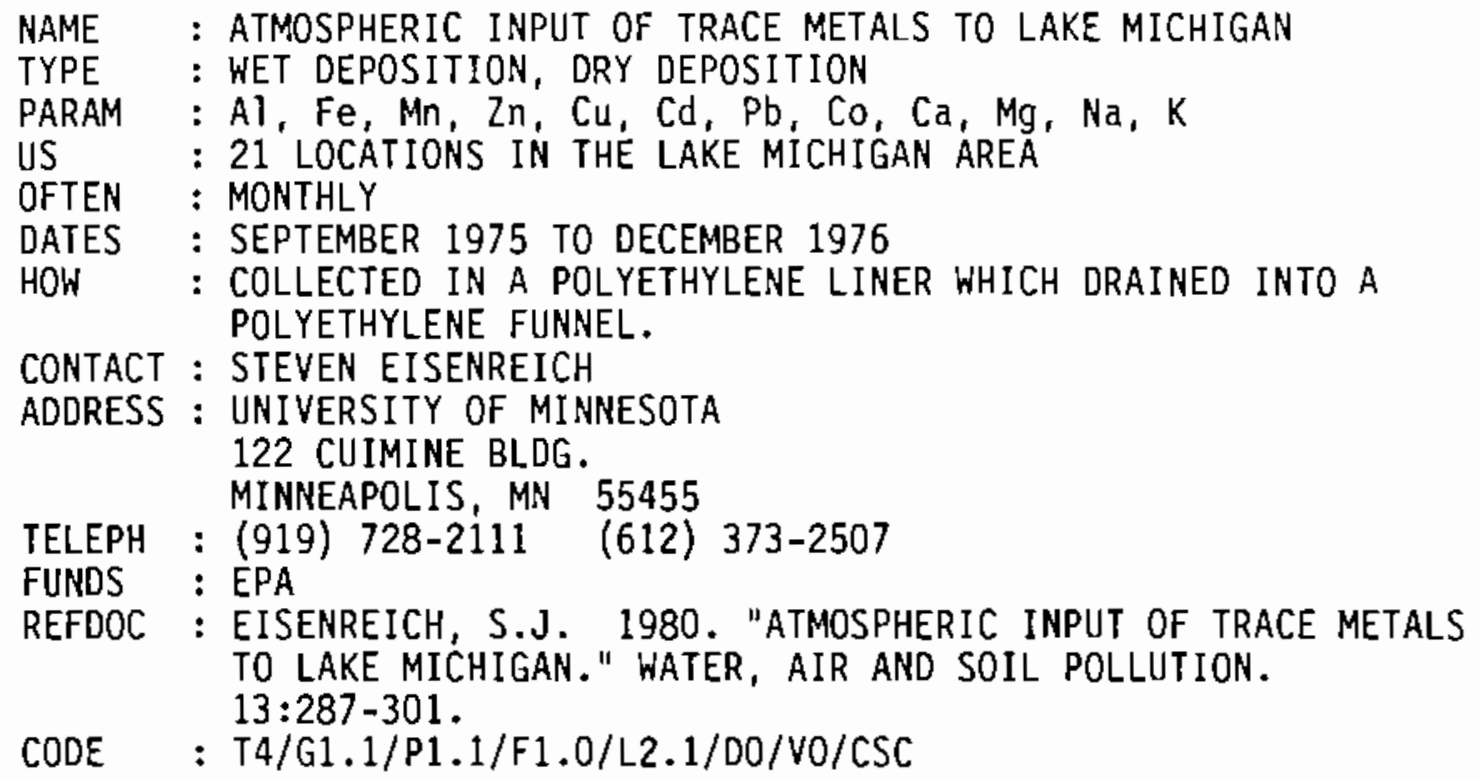




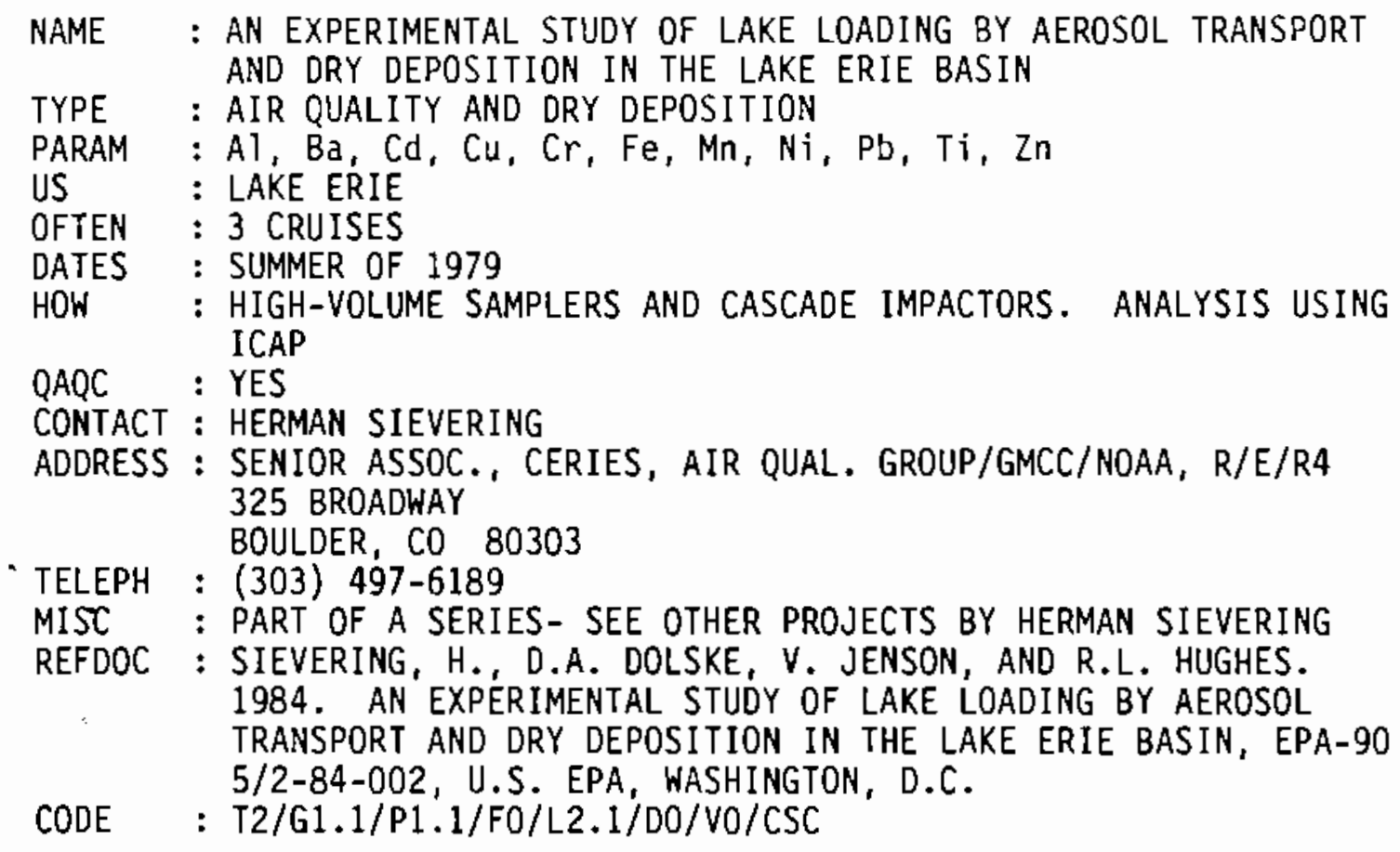




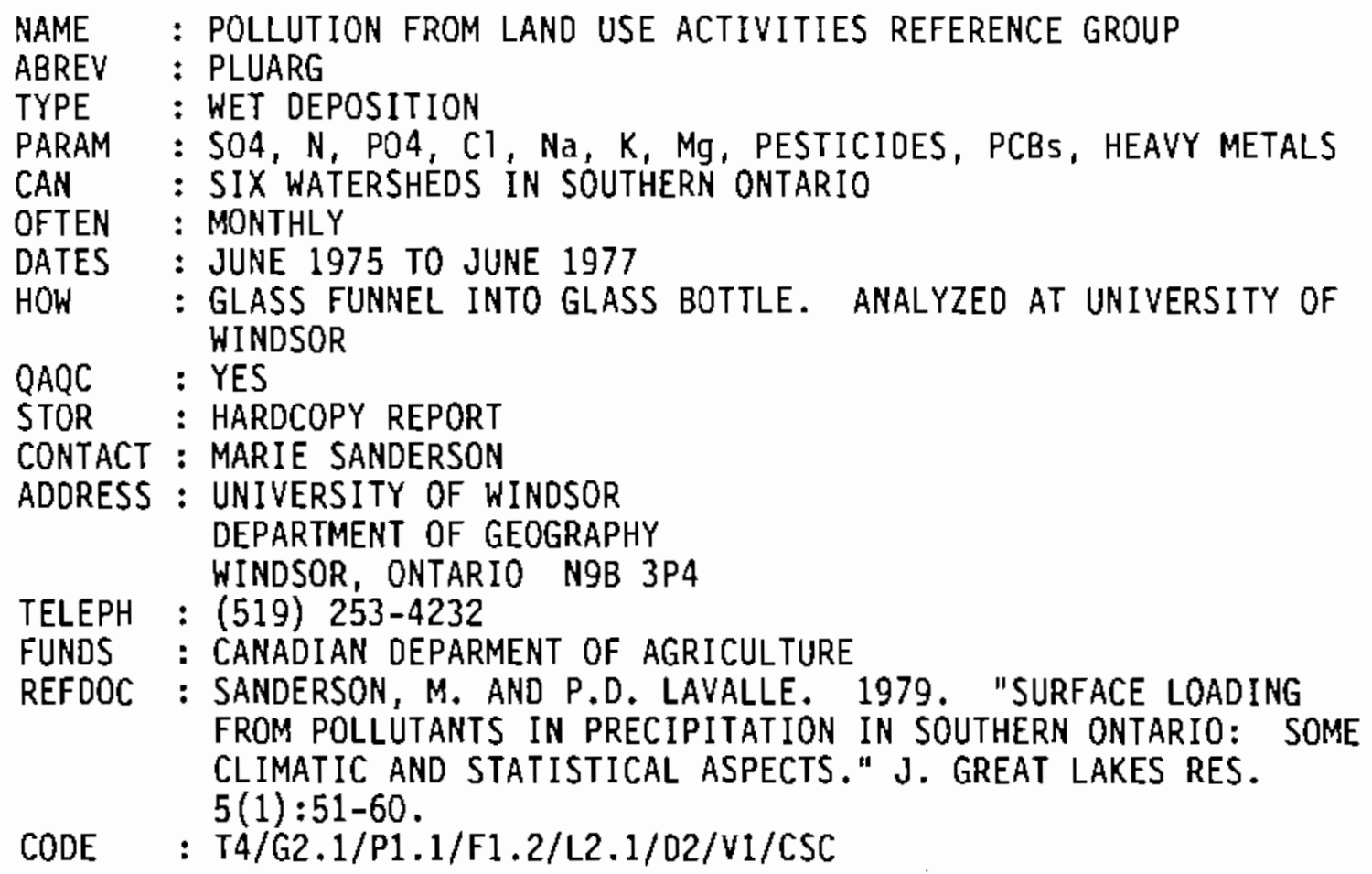


NAME : CHEMICAL ELEMENTS IN ATMOSPHERIC AEROSOL OVER SOUTHERN LAKE MICHIGAN: THE CONTRIBUTION OF THE LAKE SOURCE

TYPE : AIR QUALITY

PARAM : Al, $\mathrm{Ca}, \mathrm{Cd}, \mathrm{Cu}, \mathrm{Fe}, \mathrm{Mg}, \mathrm{Mn}, \mathrm{Mo}, \mathrm{Na}, \mathrm{Ni}, \mathrm{Pb}, \mathrm{Ti}, \mathrm{Sn}, \mathrm{V}, \mathrm{Zn}$

US : 1 SITE IN THE CITY OF CHICAGO WATER INTAKE CRIB

DATES : MAY 1978 TO JANUARY 1979

HOW : 5 STAGE CASCADE IMPACTOR. ANALYSIS WITH ICAP

QAQC : DUPLICATE ANALYSIS OF REPLICATE SAMPLES AND SPIKED SAMPLES

CONTACT : HERMAN SIEVERING

ADDRESS : SENIOR ASSOC., CERIES, AIR QUAL. GROUP/GMCC/NOAA, R/E/A/R4 325 BROADWAY

BOULDER, CO 80303

TELEPH : (303) 497-6189

FUNDS : EPA

- MISC : PART OF A SERIES- SEE OTHER PROJECTS BY HERMAN SIEVERING

REFDOC : SIEVERING, H., AND D. DOLSKE. 1984. CHEMICAL ELEMENTS IN A ATMOSPHERIC AEROSOL OVER SOUTHERN LAKE MICHIGAN: THE

CONTRIBUTION OF THE LAKE SOURCE, EPA-904-84-001, APPENDIX D, US EPA, WASHINGTON, D. C.

CODE : T2/G1.1/P2.1/F0/L2.1/DO/VO/CSC 


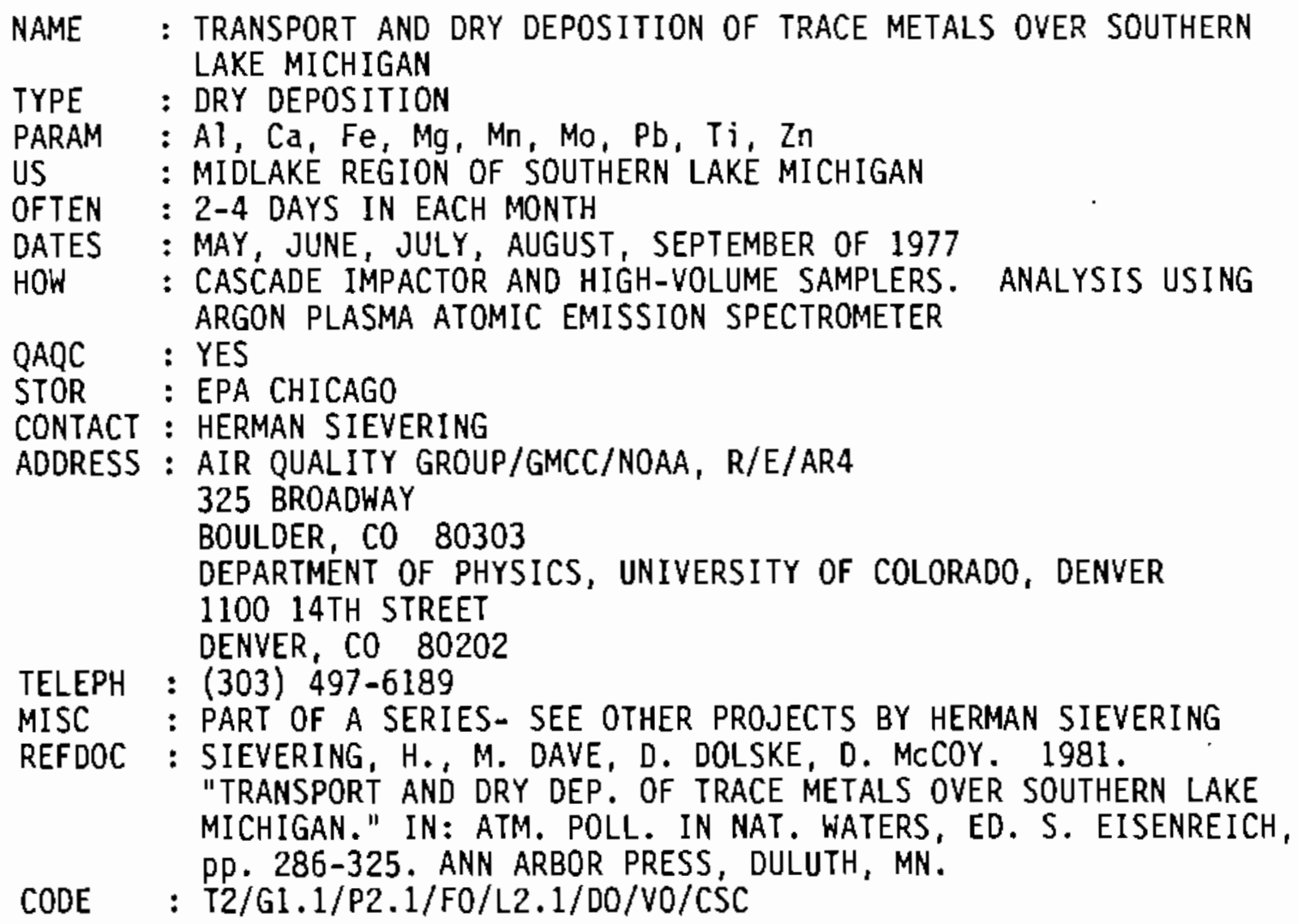




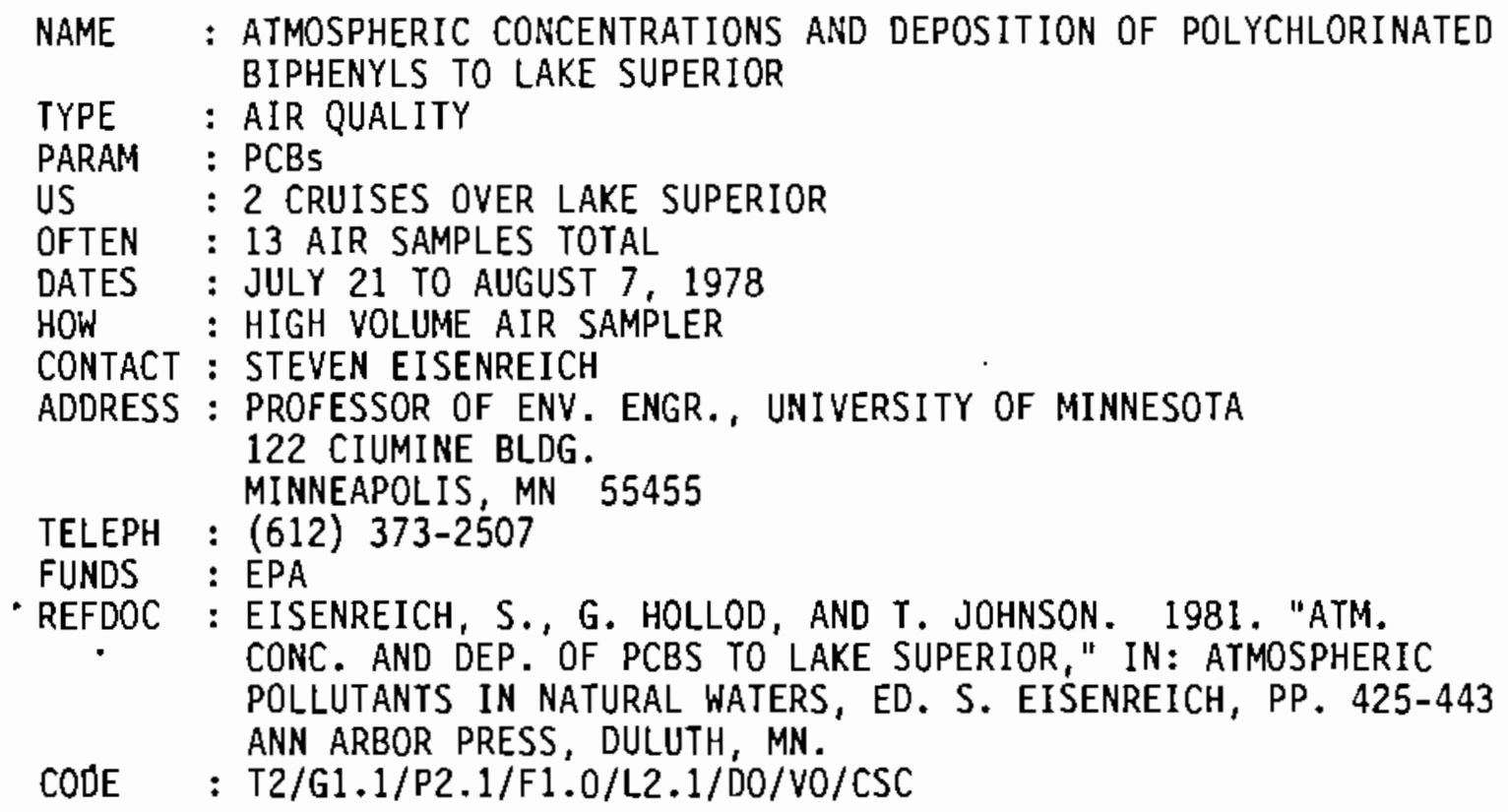




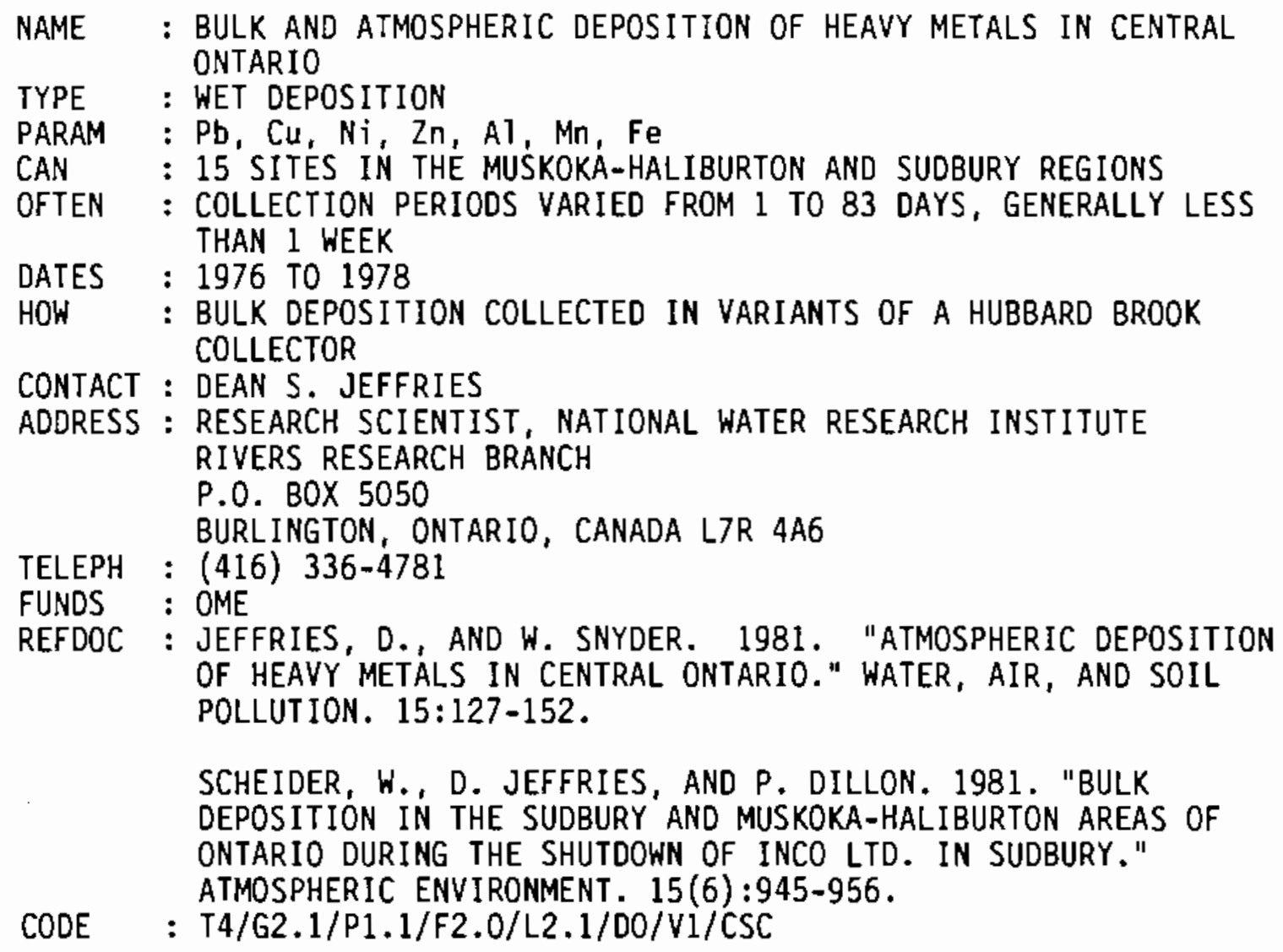




\section{DISTRIBUTION}

No. of

Copies

OFFSI TE

30 DOE Technical Information Center

2 G. J. Foley

U.S. Environmental Protection Agency

Acid Deposition Planning Staff (RD-676)

401 M Street, SW

Washington, OC 20460

W. E. Fallon

U.S. Environmental Protection Agency

Acid Deposition Planning Staff (RO-676)

401 M Street, SW

Washington, DC 20460

D. C. Kelley

U.S. Environmental Protection Agency

Acid Deposition Planning Staff (RD-676)

401 M. Street, SW

Washington, DC 20460

J. Young

Atmospheric Environment Service

4905 Dufferin Street

Downsview, Ontario

Canada M3H 5 T4
No. of

Copies

ONSITE

DOE Richland Operations Office

J. J. Sutey/P. K. Clark

26 Pacific Northwest Laboratory

M. Y. Ballinger (2)

W. R. Barchet

M. 0. Bettinson

E. G. Chaprian (2)

J. Defferding

ט. W. Dragnich

C. E. Elderkin

C. S. Glantz (2)

M. J. Graham

J. M. Hales

P. C. Hays

N. S. Laulainen

D. S. Renne

B. L. Steelman

J. A. Stott lemyre

R. E. Wi iduny

Publishing Coordination (2)

Technical Report Files (5) 


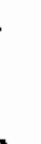

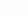

